\title{
CONCEPTUAL AND SCIENTIFICALLY- METHODICAL PRINCIPLES OF REALIZATION OF POLICY IN THE FIELD OF THE STATE BORDER SECURITY IN UKRAINE
}

Collective monograph

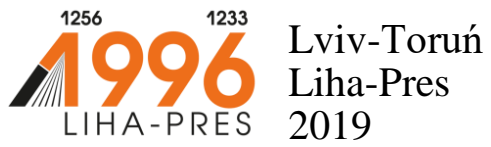




\section{Reviewers:}

Prof. dr hab. Sabina Grabowska, Uniwersytet Rzeszowski / University of Rzeszow (Republic of Poland);

Prof. dr hab. Joanna Marszalek-Kawa, Uniwersytet Mikołaja Kopernika $w$ Toruniu / Nicolaus Copernicus University (Republic of Poland).

Conceptual and scientifically-methodical principles of realization of policy in the field of the State border security in Ukraine : collective monograph / O. Shynkaruk, Yu. Babii, V. Kyrylenko, D. Kupriyenko, O. Farion, A. Babaryka. - Lviv-Toruń : Liha-Pres, 2019. - 112 p.

ISBN 978-966-397-184-1

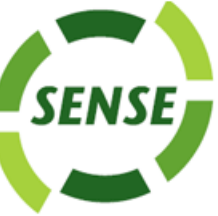

Liha-Pres is an international publishing house which belongs to the category "C" according to the classification of Research School for Socio-Economic and Natural Sciences of the Environment (SENSE) [isn: 3943, 1705, 1704, 1703, 1702, 1701; prefixMetCode: 978966397]. Official website www.sense.nl. 


\section{CONTENTS}

ADAPTIVE MODEL OF CRIMINAL ACTIVITY

IDENTIFICATION ON THE CASE OF THE STATE

BORDER SERVICE OF UKRAINE

Oleh Shynkaruk

METHODOLOGICAL APPARATUS FOR MONITORING

MOVING OBJECTS AT THE STATE BORDER

BY A RADAR STATION

Yuliia Babii

IRREGULAR MIGRATION AS AN OBJECT OF RESEARCH

IN THE CONTEXT OF FINDING WAYS TO IMPROVE THE

EFFECTIVENESS OF ORGANIZING COUNTERACTION

IN THE AREA OF RESPONSIBILITY OF CHOP BORDER GUARD

DETACHMENT OUTSIDE BORDER CROSSING POINTS

Volodymyr Kyrylenko.

THE METHOD OF COORDINATED TRAINING FOR JOINT

ACTIONS OF FORCES OF SECURITY AND DEFENSE SECTOR

OF UKRAINE OF DIFFERENT AFFILIATIONS IN THE CONTEXT

OF AN INTERNATIONAL COOPERATION (ON THE EXAMPLE

OF BORDER SECURITY GUARANTEEING ENTITIES)

Dmytro Kupriyenko

METHOD OF ASSESSMENT OF THE STATE OF

INFORMATIONAL AND ANALYTICAL ACTIVITY

OF OPERATING UNITS OF THE STATE BORDER

GUARD SERVICE OF UKRAINE

Oleh Farion 68

STUDY OF DETECTION AND TRACKING ALGORITHMS

OF MOVING OBJECTS IN VIDEO SEQUENCES

FROM VIDEO SURVEILLANCE CAMERAS

Anatolii Babaryka 89 


\section{ADAPTIVE MODEL OF CRIMINAL ACTIVITY IDENTIFICATION ON THE CASE OF THE STATE BORDER SERVICE OF UKRAINE}

\section{Oleh Shynkaruk}

\section{INTRODUCTION}

The State Border Guard Service of Ukraine (hereinafter referred to as SBGSU) is one of the subjects of the security and defense sector, implementing the state policy in the field of state border security and protection of Ukraine's sovereign rights in its exclusive (maritime) economic zone ${ }^{1}$.

To this end, the SBGSU undertakes a series of activities, in particular: taking part in the fight against organized crime, combating illegal migration, terrorism, ending the activities of illegal militarized or armed formations (groups), organized groups and criminal organizations.

The results of the operational and service activities of the authorities and units of the SBGSU indicate that the effectiveness of the fight against crime is enhanced by timely detection of crimes, identification of their type and carrying out specific measures of prevention or counteraction according to each type of crime.

A number of information sources are used to obtain or clarify the primary data on the crime and the persons involved in it. According to the results of the analysis of the received information, its authenticity and conformity with the available crime data (models of a specific type of crime) are evaluated.

Since the time it takes to commit a crime is often less than the time for obtaining and verifying the primary information about the crime, the assessment of the level of the information sufficiency loses its relevance. Inaccurate data about the preparation or the fact of committing the crime and the persons involved in it creates unfavorable conditions for timely counteraction to it and increases the cost of resources available at the border guard agencies and units.

At the same time, each type of crime is characterized by its inherent methods (techniques) of preparation and committing. Therefore, measures to counteract a particular type of crime should be adequate to the tactics of the

\footnotetext{
${ }^{1}$ Pro nacionaljnu bezpeku Ukrajiny : Zakon Ukrajiny : vid 21.06.2018 № 2469-VIII. URL : http:// www.rada.gov.ua. (in Ukrainian)
} 
offenders. To this end, a number of hypotheses (the probable place and time of the crime, the composition of persons involved in the crime and their role, modes of action, directions and possible tricks) are put forward based on the analysis of the actions of the criminals.

Subsequently, the most plausible hypothesis is determined (a crime model is formed) and the appropriate model of crime prevention or suppression (purpose, tasks, areas of action, composition of forces and means, sequence and methods of action, expected results) is worked out. This allows to distribute forces and resources and to form accurate tasks for their use.

Thus, for the timely prevention, detection and suppression of crimes on the state border of Ukraine, it is necessary to search for such tools that would allow to identify a specific type of crime.

\section{Analysis of recent publications}

Scientific knowledge of the issues of security of the state border of Ukraine, in particular counteraction to threats, was carried out by a considerable number of scientists.

For example, in the work $^{2}$, tools were proposed to assess the state of exacerbation of the situation in the border area when assessing the dynamics of the threat to the territorial integrity of the state.

In the work ${ }^{3}$, the procedure for determining the degree of correspondence of an object of attention to the data on a potential illegal migrant at border crossing points is proposed.

In another work ${ }^{4}$, a model of detecting lawbreakers at the state border was developed using a hierarchical fuzzy logical deduction.

${ }^{2}$ Ghorodnov V.P., Binjkovsjkyj O. A., Karatajev R. Gh., Kyrylenko V. A. (2009) Metodyka vyznachennja pokaznyka stupenja zaghostrennja obstanovky v prykordonnij sferi pry ocinci dynamiky formuvannja zaghrozy terytorialjnoji cilisnosti derzhavy [The method of determining the indicator of the degree of exacerbation of the situation in the border area in assessing the dynamics of the formation of threat to the territorial integrity of the state]. Zbirnyk naukovykh pracj, no. 46. pp. 24-31. (in Ukrainian)

${ }^{3}$ Kyrylenko V. A, Gorodnov V. P, Karatayev R. G, Tsibrovskyi M. Yu. (2008) Model of determining the degree of correspondence of an object of attention to the data about a potential illegal migrant at border crossing points [Model for determining whether the object of attention is subject to data on a potential illegal migrant at border crossings]. Zbirnyk naukovykh pracj, no. 46. pp. 29-34.

4 Androshhuk O.S., Mykhajlenko O. V. (2014) Modelj vyjavlennja porushnykiv zakonodavstva na derzhavnomu kordoni iz zastosuvannjam ijerarkhichnogho nechitkogho loghichnogho vyvodu [A model for determining the degree of compliance of an object of attention with data on a potential illegal migrant at border crossings]. Modern information technologies in the field of security and defense. No.1(19). pp. 5-10. 
In the work ${ }^{5}$, a model of crime recognition was developed by the Operational Investigation Department of the State Border Guard Service of Ukraine.

In the work ${ }^{6}$, the tools for prediction unlawful activities on the state border outside the checkpoints are proposed.

The results of the analysis of these and other publications and studies indicate that the issue of the crime type identification in the area of responsibility of the bodies (units) of the SBGSU was not considered.

Therefore, the relevance of the topic of the research is stipulated by the need for an in-depth study of the problem of crime identification on the state border of Ukraine for the scientific tools formation in the operational and service activities of border protection authorities (units) for improving the effectiveness of combating crime.

The purpose of the article is to formulate an adaptive model of the criminal activity identification on the state border of Ukraine.

\section{Outline of the Main Research Material}

The State Border Guard Service of Ukraine, in accordance with Ukrainian legislation, directs its efforts of the operational service activity of the subordinate border security units to:

counteracting illegal migration, contraband and other unlawful activity at the state border controlled frontier area, at the checkpoints via the state border of Ukraine, border control enter-exit points;

participation in the activities directed to combating terrorism, to stop the activities of illegal or combatant formations (groups), organized groups and criminal organizations revealing and stopping criminal offenses, etc. .

According to the tasks assigned and specific character of the SBGSU operational-service activity, individually or in interaction with other lawenforcement agencies and services it accomplishes counteraction (prevention, disclosing, termination) against the crimes indicated in the

5 Cyghykal P. O, Farion O. B. (2017) Modelj rozpiznannja zlochyniv operatyvnorozshukovym viddilom Derzhavnoji prykordonnoji sluzhby Ukrajiny [Model of crime recognition by the Operational Investigation Division of the State Border Guard Service of Ukraine]. Zbirnyk naukovykh pracj, no. 1(71). pp. 238-255.

${ }^{6}$ Onyshhuk S. V. (2014) Proghnozuvannja protypravnoji dijaljnosti na derzhavnomu kordoni poza punktamy propusku na osnovi nechitkoji loghiky [Predicting unlawful activities at the state border beyond the border crossing points based on fuzzy logic]. Zbirnyk naukovykh pracj, no. 3(40). pp. 198-202.

${ }^{7}$ Pro zatverdzhennja Polozhennja pro orghan okhorony derzhavnogho kordonu Derzhavnoji prykordonnoji sluzhby Ukrajiny: nakaz MVS vid 30.11.2018. \# 971. Kyjiv. URL: http://search.ligazakon.ua/1_doc2.nsf/link1/RE32920.html. (in Ukrainian) 
table 1 , responsibility for the crimes commitment which is determined by the Criminal Code of Ukraine ${ }^{8}$.

It the course of the operational-service activity of the SBGSU border protection bodies information is obtained about persons, events (unlawful events) at the state border (for example, offence commitment, detention of a person at the port-of-entry).

Table 1

List of crimes (determined by the Criminal Code articles), by the forces and means of the border protection authorities within the Ukrainian legislation

\begin{tabular}{|c|c|c|}
\hline N/n & $\begin{array}{c}\text { Article } \\
\text { number }\end{array}$ & Title \\
\hline 1 & p. 110 & $\begin{array}{c}\text { Encroachment on territorial } \\
\text { integrity and inviolability of Ukraine }\end{array}$ \\
\hline 2 & p. 149 & $\begin{array}{c}\text { Human trafficking or other } \\
\text { illegal transaction concerning a person }\end{array}$ \\
\hline 3 & p. 201 & Smuggling \\
\hline 4 & p. 249 & Illegal fishing, animal or other water production industry \\
\hline 5 & p. 255 & Creation of crime organization \\
\hline 6 & p. 258 & Terroristic act \\
\hline 7 & p. $258^{1}$ & Involvement into terroristic act commitment. \\
\hline 8 & p. $258^{2}$ & Public appeal to commit a terroristic act \\
\hline 9 & p. $258^{3}$ & Creation of terroristic group or organization \\
\hline 10 & p. $258^{4}$ & Promotion of the terroristic act \\
\hline 11 & p. $258^{5}$ & Financing a terroristic act \\
\hline 12 & p. 260 & $\begin{array}{c}\text { Creation of non - statutory paramilitary } \\
\text { or armed formations }\end{array}$ \\
\hline 13 & p. 305 & $\begin{array}{c}\text { Smuggling in drugs, psychotropic substances, their } \\
\text { analogues or precursors, false medicines }\end{array}$ \\
\hline 14 & p. 332 & $\begin{array}{c}\text { Unlawful persons transition } \\
\text { over the state border of Ukraine }\end{array}$ \\
\hline 15 & p. 333 & $\begin{array}{c}\text { Irregularities in the international transportation of goods } \\
\text { which are liable to the export control }\end{array}$ \\
\hline 16 & p. $358^{4}$ & Usage of knowingly forged document \\
\hline 17 & & Other crimes \\
\hline
\end{tabular}

This information is accumulated in the relevant databases of different kinds. Thus, information about persons who are denied to enter Ukraine according to the legislation or temporarily restricted to leave Ukraine, in

${ }^{8}$ Kryminaljnyj kodeks Ukrajiny : Zakon Ukrajiny \# 2341 III vid 05.04.2001 rok URL : http://zakon3.rada.gov.ua / laws/show/2341-14/para273. (in Ukrainian) 
accordance with the assignment of the law enforcement agencies, persons, hiding from the inquest bodies, investigation and court, avoiding to serve criminal sentences, with invalid, stolen and lost documents for the right to leave the country is received by the information-telecommunication system (further - «Gart-1»). Besides, the information of different type about events at the state border is inserted into the databases of the information and telecommunication systems (further - ITS) ${ }^{9,10,11}$ (table 2).

Table 1

\section{Databases of the information and telecommunication systems}

\begin{tabular}{|c|c|}
\hline Databases & Speciality \\
\hline «Gart-2» & ITS operational duty service \\
\hline «Gart-3» & ITS border guard service \\
\hline «Gart-5» & ITS informational analyst service \\
\hline «Gart-10» & ITS operational search service \\
\hline «Gart-12» & ITS marine security \\
\hline «Gart-14» & ITS control and coverage of the situation \\
\hline «Gart-21» & ITS internal security units \\
\hline RE & registration of the events \\
\hline RPA & risk profile analysis \\
\hline OM & operational messages \\
\hline IC & interactive reference \\
\hline CDSR & central data storehouse repository \\
\hline
\end{tabular}

In order to provide the coverage of the situation telecommunication system of geoinformation support «Gart-17» has been developed and implemented in all corporate systems. This system is kept up to date.

9 Pro zatverdzhennja Polozhennja pro informacijno-telekomunikacijnu systemu prykordonnogho kontrolju "Ghart-1" Derzhavnoji prykordonnoji sluzhby Ukrajiny : nakaz DPSU vid 30.09.2008. № 810. URL : https://zakon.rada.gov.ua/ laws/show/z1086-08. (in Ukrainian)

${ }^{10}$ Streljbicjkyj M. A. (2018) Tekhnologhija zabezpechennja funkcionaljnoji bezpeky integhrovanoji informacijnoji systemy Derzhprykordonsluzhby na stadiji modernizaciji [Technology of providing functional security of the State Border Service's integrated information system at the stage of modernization], Kiev, 348 p. (in Ukrainian)

${ }^{11}$ Shynkaruk O. M., Fedorchenko A. V. (2015) Analiz dosvidu stvorennja ta vykorystannja integhrovanykh telekomunikacijnykh system «Ghart» v Derzhavnij prykordonnij sluzhbi Ukrajiny [Analysis of the experience of creation and use of integrated telecommunication systems «Hart» in the State Border Service of Ukraine]. Zbirnyk naukovykh pracj, no. 2(64), pp. 221-233. (in Ukrainian) 
To exchange the information with the individuals of the integrated border management on the issues of prevention entry-exit for persons, who are prohibited to enter or leave Ukraine according to the legislation ITC «Arcan» is used. Besides, the information about lost (invalid) documents, information about persons, who are in search, stolen vehicles etc. Based on the analysis of information of the SBGSU databases about unlawful events at the state border of Ukraine and information obtained using the possibilities of ITC «Arcan» informational signs of crimes and persons related to them have been received. These indications in total characterize typical crime models, which are presented in table 2.

Table 2

\section{Complex of information indicators of criminal activity on the state border of Ukraine by the types of crimes counteraction to which refers to the SBGSU competency}

\begin{tabular}{|l|}
\hline Name of information indicator \\
\hline Complex No 1. Information indicators of crime "Smuggling" \\
\hline $\begin{array}{l}\text { Complex No 2. Information indicators of crime "Trafficking in persons or other } \\
\text { illegal transactions in respect of a person" }\end{array}$ \\
\hline $\begin{array}{l}\text { Complex No 3. Information indicators of crime "Smuggling of drugs, psychotropic } \\
\text { substances, their analogous or precursors and counterfeit medicines" }\end{array}$ \\
\hline Complex No 4. Information indicators of crime "Terrorist act" \\
\hline Complex No 5. Information indicators of crime "Conspiring to commit the terrorist act" \\
\hline $\begin{array}{l}\text { Complex No 6. Information indicators of crime "Organization of unforeseen } \\
\text { by law paramilitary units or armed groups" }\end{array}$ \\
\hline $\begin{array}{l}\text { Complex No 7. Information indicators of crime "Illegal human trafficking across } \\
\text { the state border of Ukraine" }\end{array}$ \\
\hline
\end{tabular}

Information indicators shown in table 2 by the sources of obtaining and contents meet different criteria of credibility which are assessed by method «4×4» in SBGSU ${ }^{12}$.

The given method allows making an assessment of credibility of information source and its contents. Thus an assessment of credibility of information sources is carried out by the following criteria:

\footnotetext{
${ }^{12}$ Pro zatverdzhennja Instrukciji pro porjadok ocinky informaciji za metodom $4 \mathrm{kh} 4:$ nakaz Administraciji Derzhavnoji prykordonnoji sluzhby Ukrajiny vid 19.01.08 \# 44. Kiev : ADPSU, 2008. 28 p. (in Ukrainian)
} 
«A»-source concerning which there is no suspicion in falsifying or distortion of information (active members of law enforcement institutions, court officials, prosecutors, evidence etc.);

$\langle\mathrm{B} »-$ indicates the possibility of an error while inputting the data and give to electronic material databases (recordings in account books, law enforcement databases etc.);

$\langle\mathrm{C} »-$ indicates the necessity of additional verification of each piece of information obtained from the source of this category;

«D»- is assigned to all new sources of information credibility of which is unknown or cannot be identified at the given moment.

The assessment of credibility of the contents is carried out according to the following criteria:

«1»- for information credibility of which is beyond any doubt;

«2»- for information known personally to the source, but unknown to the staff member who receives it;

«3»- for information known personally to the source but not confirmed by the previously received information;

«4»- for information which is personally unknown to the source and it cannot be confirmed.

Overall assessment of information credibility is displayed as the code: $A 1, A 2, B 1, B 2, A 3, A 4, B 3, B 4, C 1, C 2, C 3, C 4, D 1, D 2, D 3, D 4$.

Each element of the denoted set of information credibility can be represented by a point on the axis of abscissas and has ordinate - meaning of the indicator of basic information credibility $y_{0}$ (toward a decrease of credibility) from $16 / 16$ to $1 / 16$ on axis of ordinates respectively.

Monotony of decrease of information credibility makes it possible to approximately present the initial credibility in the form of the equation of straight line specified by points $y_{\max }\left(x_{1}\right), y_{\min }\left(x_{4}\right)^{13}$ :

$$
y_{0}=y_{\max }-\operatorname{tg} a \cdot x
$$

where: $\operatorname{tg} \varphi=\frac{y_{\max }-y_{\min }}{x_{D 4}-x_{A 1}}$;

$x$ - assessment of indicator of information credibility by method « $4 \times 44 »$;

$y_{\min }-$ minimum meaning of the indicator of information credibility;

${ }^{13}$ Ghorodnov V. P. Karatajev R. Gh., Kyrylenko V. A. (2009) Modelj vyznachennja stupenja vidpovidnosti ob'jekta uvaghy danym pro potencijnogho porushnyka v punktakh propusku cherez derzhavnyj kordon [Model for determining the degree of compliance of the object of attention to the information about the potential offender at the border crossing points]. Zbirnyk naukovykh pracj, no. 46. pp. 18-23. 
$y_{\max }-$ maximum meaning of the indicator of information credibility;

$\varphi-$ angle between the straight line and axis of abscissas.

Assessment of the degree of coherence of the initial and the necessary indicators composition is fulfilled by means of components comparison of needed and provided information vectors. Obtaining the correct data may be carried out by the results of the assessment.

Indicator of the information coherence degree $(\cos \varphi)$ may be presented as cosine of angle between vectors of needed and provided information which is calculated as:

$$
\cos \varphi=\frac{1}{a b} \sum_{i=1}^{n} a_{i} b_{i}=\gamma
$$

where: $a$ and $b$ - length of the vector of needed and provided information; $\left(a_{1}, a_{2}, \ldots, a_{\mathrm{n}}\right)$ and $\left(b_{1}, b_{2}, \ldots, b_{\mathrm{n}}\right)-$ coordinates of vectors $a$ and $b$.

Within complete coherence the angle between vectors is equal to zero $(\varphi=0)$ and $\cos \varphi=1$. Criterion of adequacy for the level of information coherence is achieved on condition $\cos \varphi \geq \gamma(0<\gamma \leq 1)$.

Let us consider as an example the process of crime identification by the provided information about its indicators.

Example. The Central office of border guard service department "Reni" of Izmail border unit of the Southern regional office SBGSU got two messages.

Message No1. May, $12^{\text {th }} 2019$ at 20.30 a group of seven people tried to buy bus tickets to Romania. But they seemed confused and failed to explain the point of their destination in Romania, then they suddenly disappeared. The information was given by the administrator of the bus terminal who provided reliable information before.

Message No 2. On May 12, 2019 at 21: 20 a group of 7 people, looking like foreign citizens, was detected near the housing cooperative "Prydunaiskyi" of Reni district. They were walking along the forest belt near Reni - Giurgiulesti highway, accompanied by a member of the cooperative, heading for his house. The information was received from an employee of Reni police department, who was resting in the country house of the abovementioned cooperative.

Task. To identify the crime according to the available information on the signs of the crime by determining the degree of compliance of the information obtained with the data of typical models of crimes (Tables 1;2).

Decision. Under the conditions of the example given, the information on message No. 1 was evaluated using method 4 as meeting the reliability 
criterion A $3=x=12 / 16$. Primary assessment of the information reliability is obtained by the formula:

$$
\operatorname{tg} \varphi=\frac{y_{\text {max }}-y_{\text {min }}}{x_{A 1}-x_{D 4}}, y_{\mathrm{n}}=y_{\text {max }}-\operatorname{tg} a \cdot x,
$$

where: $n$ is the message number.

As a result of calculations we receive a value $y_{1}=0,75$.

To determine which of the typical models of crimes the information of the received message (hereinafter - the object of attention) belongs to, it is necessary to assess the belonging of the received information (with its components) to each of the sets specified in Table 2. Here, the value of the cosine of the angle between the reference vectors of each set and the vector of the available information can be an indicator of consistency.

According to this example, it was found that the object of attention presented in table 3 in the fourth column corresponds to the set of information features No. 8.

In Table 3 the following value was assumed:

$\vec{a}_{o}$ - reference vector of information signs of a typical crime model; $\vec{b}_{1}-$ vector of available information on the message No. $1 ; 《+»-$ presence of a sign; «-»- absence of a sign.

After calculations by the formula (2) we obtain $\cos \varphi_{1}=\gamma_{8}=0,577$. Belonging of the available information signs to other sets of crimes' information signs has correspondingly smaller value $\left(\gamma_{8} \gamma_{1}, \ldots, \gamma_{7}\right)$.

If all components of the vector of available information correspond to the $\vec{b}_{1}$ components of the reference vector of the necessary information $\vec{\alpha}_{1}$, the identification of the object of attention as a crime - "People smuggling across the state border of Ukraine "is" reliable". Here, the probability of compliance of the object of attention with the standard model of the crime "People smuggling across the state border of Ukraine" will be equal to one $\left(P_{\mathrm{m}}=1\right)$, where $m$ is the number of the set of information signs of the crime (Table 2). 
Summary table of components of the reference vector of separate information signs of set No. 7 «People smuggling across the state border of Ukraine» (table 2) and the vector of available information according to the example

\begin{tabular}{|c|c|c|c|c|}
\hline \multirow[t]{2}{*}{$\begin{array}{l}\text { Seq. } \\
\text { No }\end{array}$} & \multirow{2}{*}{$\begin{array}{c}\text { Separate informational signs of the crime } \\
\text { "People smuggling across the state border } \\
\text { of Ukraine" }\end{array}$} & \multirow{2}{*}{$\begin{array}{l}\text { Reference } \\
\text { vector's } \\
\text { components } \\
\vec{a}_{o}\end{array}$} & \multicolumn{2}{|c|}{$\begin{array}{l}\text { Available } \\
\text { information vector' } \\
\text { components }\end{array}$} \\
\hline & & & $\vec{b}_{1}$ & $\vec{b}_{2}$ \\
\hline 1 & $\begin{array}{l}\text { The person is hiding not far from the state } \\
\text { border with the use of the terrain }\end{array}$ & + & - & + \\
\hline 2 & $\begin{array}{l}\text { Detection of signs of groups of persons } \\
\text { staying near the border (trampled snow, } \\
\text { cigarette butts, remnants of packaging from } \\
\text { water and food, especially those that are not } \\
\text { available in the local trade network) }\end{array}$ & + & - & - \\
\hline 3 & $\begin{array}{l}\text { The person does not speak Ukrainian or any } \\
\text { other language of EU countries, speaks an } \\
\text { unknown language }\end{array}$ & + & + & - \\
\hline 4 & $\begin{array}{l}\text { Person's appearance features testifying to its } \\
\text { possible belonging to the foreign state (skin } \\
\text { color, off-season clothes or clothes not specific } \\
\text { for citizens living in the border area, etc.) }\end{array}$ & + & - & + \\
\hline 5 & $\begin{array}{l}\text { Data on possible facilitation of illegal } \\
\text { transportation of persons across the state } \\
\text { border of Ukraine }\end{array}$ & + & - & + \\
\hline 6 & $\begin{array}{l}\text { Data on the presence of people not living in } \\
\text { the controlled border area, the border zone }\end{array}$ & + & - & + \\
\hline 7 & $\begin{array}{l}\text { Presence of people who are not members of } \\
\text { enterprises and communities engaged in } \\
\text { agricultural and other economic activities in } \\
\text { the controlled border area }\end{array}$ & + & - & + \\
\hline 8 & $\begin{array}{l}\text { Presence of premises, facilities, shelters } \\
\text { adapted for temporary and hidden stay of } \\
\text { illegal migrants in the controlled border area } \\
\text { or border zone for the purpose of their } \\
\text { further transportation across the state border }\end{array}$ & + & - & - \\
\hline 9 & $\begin{array}{l}\text { The presence of human clothing, unusual for } \\
\text { residents of border areas }\end{array}$ & + & + & - \\
\hline 10 & $\begin{array}{l}\text { The person is a citizenship of the country- } \\
\text { potential sources of illegal migrants }\end{array}$ & + & - & - \\
\hline 11 & Embarrassed and confused look of a person & + & + & - \\
\hline 12 & $\begin{array}{l}\text { The person does not have information about } \\
\text { the final destination on the territory of a } \\
\text { neighboring state }\end{array}$ & + & + & - \\
\hline 13 & $\begin{array}{l}\text { Purchase of an unusually large batch of food } \\
\text { by a local resident of the border area }\end{array}$ & + & - & - \\
\hline 14 & $\begin{array}{l}\text { Purchase of an unusually large batch of } \\
\text { goods of vital necessity by a local resident of } \\
\text { the border area }\end{array}$ & + & - & - \\
\hline 15 & $\begin{array}{l}\text { Data on persons communicating in a foreign } \\
\text { language }\end{array}$ & + & + & + \\
\hline
\end{tabular}


Otherwise, when there is a complete mismatch of all components of the vector of available information to the components of the reference vector, this incident is one that cannot happen and is "impossible", that is, the probability that the object of attention corresponds to the typical model of the specified crime will be zero $\left(P_{m}=0\right)$.

The partial coincidence of the vectors of information is characterized by the degree of their consistency and determines the importance of the probability that the object of attention is a crime related to the illegal transfer of persons across the state border of Ukraine $0 \leq P_{m} \leq 1$.

The index of the degree of information vectors consistency at full coincidence of vectors is equal to one (collinear vectors), and in case of complete difference it is equal to zero (vectors are orthogonal), and in case of complete disagreement it is equal to zero (vectors are orthogonal), which corresponds to the physical meaning of estimations and the extreme values of the probability of Pm correspondence.

However, within this range, the dependence of the degree of vector consistency is nonlinear. Therefore, the indicator of the probability of compliance of the standard model of the specified crime in the event in question may be the value of the inverse function of the indicator of vector coherence of available and reference information, $\arccos \varphi, \varphi \in\left[0 ; \frac{\pi}{2}\right]$, provided that it is reduced to a dimensionless value ${ }^{14}$ :

$$
P_{m}=1-\frac{2}{\pi} \times \arccos \left(\frac{1}{a^{m} b} \sum_{i=1}^{n^{m}} a_{i}^{m} b_{i}\right) .
$$

Formula (4) takes into account the condition of intentionally nonnegative value of the component and, therefore, the positive value of the scalar product of vectors for the evaluated information data.

As a result of additional measures taken to check the probability of compliance of the object of attention with the reference image of the model to the specified crime in this case will be equal: $\mathrm{P} 1=0.392$.

Assessment of the degree of compliance of the object of attention depends on both the probability (3), conditioned by the indicator of coherence of information vectors, reflecting the information semantic correspondence of current data to the image, which is assessed as possible,

${ }^{14}$ Medvedjev M. Gh., Pashhenko I. O. (2008) Teorija jmovirnostej ta matematychna statystyka [Probability theory and mathematical statistics]. Kiyv : «Lira-K», 536 p. (in Ukrainian) 
and on the level (1) of the ability of the source of information to provide information adequately to the event.

As a result, the assessment of the degree of compliance of the identified event with the reference image of the crime model in this case can be calculated by the multiplication probability theorem:

$$
P_{m . y}=P_{m} \times y_{0}=y_{0} \cdot\left[\frac{\pi-2}{\pi} \times \arccos \left(\frac{1}{a^{m} b} \sum_{i=1}^{n^{m}} a^{m}{ }_{i} b_{i}\right)\right] .
$$

Under the terms of the example in Message 1, the probability of an expected event (the event corresponds to a typical crime model) will equal: $\mathrm{P} 1=0,294$.

Further on, we will analyze the information on the message № 2 and get the information vector, information components of which are presented in Table 3, fifth column «Components of the existing vector $\vec{b}_{2} »$.

As a result of the calculations, similar to the processing of message № 1 , there were obtained the following data:

$$
y_{2}=0,625 ; \cos \varphi_{2}=y_{2}=0,632 ; P_{2}=0,411 \text {. }
$$

Subsequently, the total probability $(\mathrm{Pn})$ of the belonging of the information signs obtained in messages No. 1 and No. 2 of the typical crime model is determined by the following formula:

$$
P_{m}=P_{8.1}+P_{8.2}-P_{8.1} \times P_{8.2},
$$

After calculations we get $\mathrm{P} 8=0,554$. This probability of occurrence is greater than the lower limit value, which, as an example, is taken as 0.238 , and it is sufficient to take measures to prevent and combat crime.

Having time $t_{\mathrm{H}}$ there is an opportunity to make a selection of missing information signs.

The algorithm of identification of crimes based on available information about their characteristics is presented in fig. 1 . 


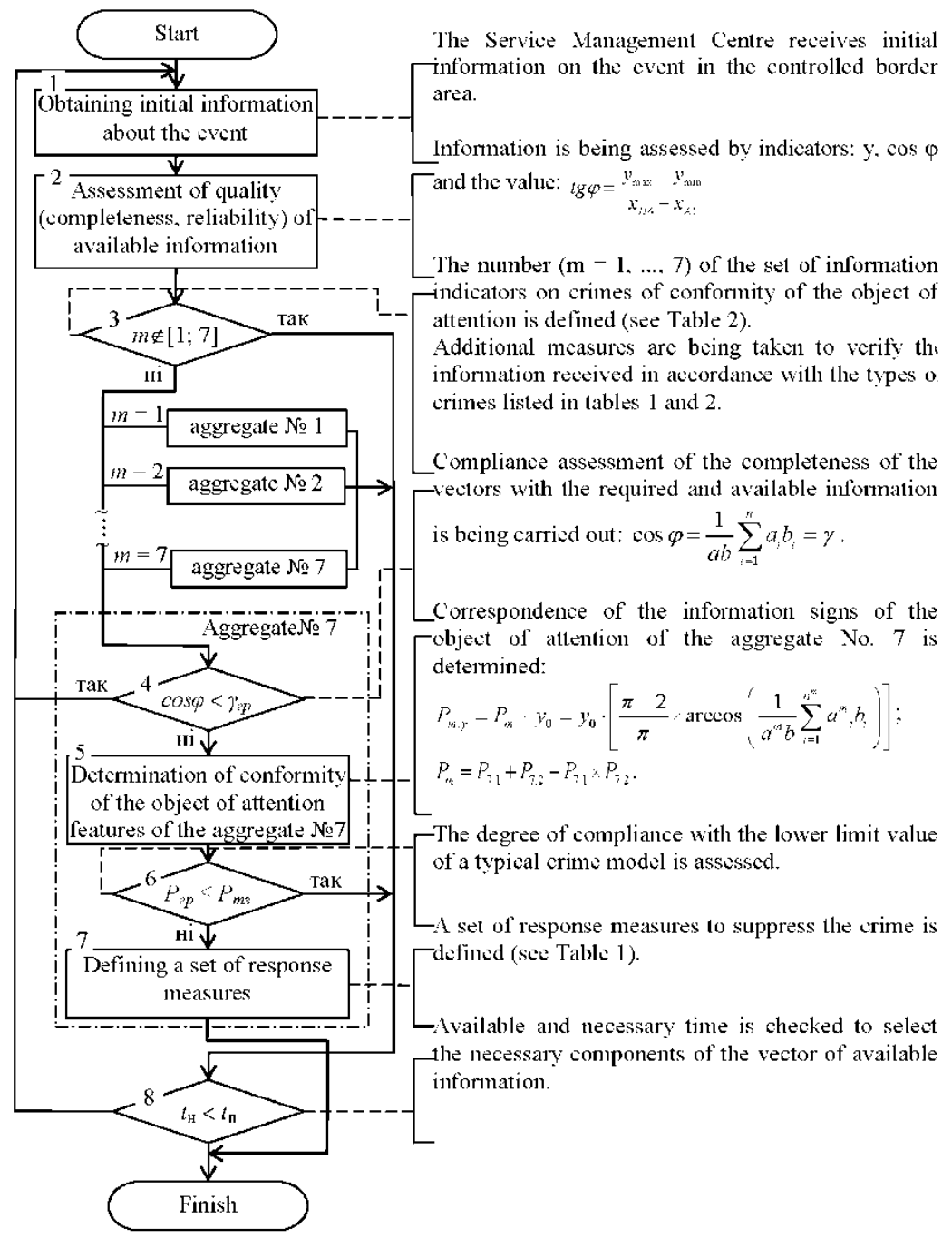

Fig. 1. Algorithm of identification of criminal activity on the State Border of Ukraine

\section{CONCLUSIONS}

A scientific approach to the formation of an adaptive model of identification of criminal activity on the state border of Ukraine is proposed. 
According to the legislation of Ukraine, a group of crimes has been selected to be countered by the forces and means of the State Border Guard Service of Ukraine.

Based on the available results of the operational and service activities of the bodies and units of the State Border Guard of the State Border Guard Service of Ukraine, a set of information indicators of crimes has been formed, for the commission of which liability is provided for in the Criminal Code of Ukraine.

Using the example, the procedure for comparing the obtained data on events at the state border in each of the aggregate of information signs of a particular type of crime and the relevant calculations is proposed.

\section{SUMMARY}

In the article the presented adaptive model and algorithm of identification of criminal activity on the state border of Ukraine provide an opportunity for the bodies and units of the State Border Protection of the SBGSU to determine the specific type of crime using the abovementioned values. As a result, this will allow for the timely adoption of measures for preventing and suppressing crimes.

This toolkit may also be used in other law enforcement agencies of Ukraine to identify criminal activity by its types.

Thus, the proposed adaptive model and algorithm of identification of criminal activity on the state border of Ukraine provide an opportunity for the bodies and units of the state border protection of the SBGSU to determine the specific type of crime using these expressions. As a result, it will allow taking timely measures to prevent and suppress crimes.

An adaptive model of the criminal activity identification according to a specific type of crime, which is being prepared or can be committed on the state border of Ukraine, is proposed. Using the presented algorithm, the Border Police and Border Protection Authorities and Departments are enabled to identify the type of crime at once and to take appropriate response measures.

This toolkit can also be used for other law enforcement agencies of Ukraine.

\section{REFERENCES}

1. Pro nacionaljnu bezpeku Ukrajiny : Zakon Ukrajiny : vid 21.06.2018 № 2469-VIII. URL : http:// www.rada.gov.ua. (in Ukrainian)

2. Ghorodnov V.P., Binjkovsjkyj O. A., Karatajev R. Gh., Kyrylenko V. A. (2009) Metodyka vyznachennja pokaznyka stupenja zaghostrennja obstanovky $\mathrm{v}$ prykordonnij sferi pry ocinci dynamiky formuvannja zaghrozy terytorialjnoji cilisnosti derzhavy [The method of 
determining the indicator of the degree of exacerbation of the situation in the border area in assessing the dynamics of the formation of threat to the territorial integrity of the state]. Zbirnyk naukovykh pracj, no. 46. pp. 24-31. (in Ukrainian)

3. Kyrylenko V. A, Gorodnov V. P, Karatayev R. G, Tsibrovskyi M. Yu. (2008) Model of determining the degree of correspondence of an object of attention to the data about a potential illegal migrant at border crossing points [Model for determining whether the object of attention is subject to data on a potential illegal migrant at border crossings]. Zbirnyk naukovykh pracj, no. 46. pp. 29-34. (in Ukrainian)

4. Androshhuk O. S., Mykhajlenko O. V. (2014) Modelj vyjavlennja porushnykiv zakonodavstva na derzhavnomu kordoni iz zastosuvannjam ijerarkhichnogho nechitkogho loghichnogho vyvodu [A model for determining the degree of compliance of an object of attention with data on a potential illegal migrant at border crossings]. Modern information technologies in the field of security and defense. no. 1(19). pp. 5-10. (in Ukrainian)

5. Cyghykal P. O, Farion O. B. (2017) Modelj rozpiznannja zlochyniv operatyvno-rozshukovym viddilom Derzhavnoji prykordonnoji sluzhby Ukrajiny [Model of crime recognition by the Operational Investigation Division of the State Border Guard Service of Ukraine]. Zbirnyk naukovykh pracj, no. 1(71). pp. 238-255. (in Ukrainian)

6. Onyshhuk S. V. (2014) Proghnozuvannja protypravnoji dijaljnosti na derzhavnomu kordoni poza punktamy propusku na osnovi nechitkoji loghiky [Predicting unlawful activities at the state border beyond the border crossing points based on fuzzy logic]. Zbirnyk naukovykh pracj, no. 3(40). pp. 198-202. (in Ukrainian)

7. Pro zatverdzhennja Polozhennja pro orghan okhorony derzhavnogho kordonu Derzhavnoji prykordonnoji sluzhby Ukrajiny: nakaz MVS vid 30.11.2018. \# 971. Kyjiv. URL: http://search.ligazakon.ua/ 1_doc2.nsf/link1/RE32920.html. (in Ukrainian)

8. Kryminaljnyj kodeks Ukrajiny : Zakon Ukrajiny \# 2341 III vid 05.04.2001 rok URL: http://zakon3.rada.gov.ua/laws/show/234114/para273. (in Ukrainian)

9. Pro zatverdzhennja Polozhennja pro informacijno-telekomunikacijnu systemu prykordonnogho kontrolju "Ghart-1" Derzhavnoji prykordonnoji sluzhby Ukrajiny : nakaz DPSU vid 30.09.2008. № 810. URL : https://zakon.rada.gov.ua/ laws/show/z1086-08. (in Ukrainian)

10. Streljbicjkyj M. A. (2018) Tekhnologhija zabezpechennja funkcionaljnoji bezpeky integhrovanoji informacijnoji systemy Derzhprykordonsluzhby na stadiji modernizaciji [Technology of providing 
functional security of the State Border Service's integrated information system at the stage of modernization], Kiev, 348 p. (in Ukrainian)

11. Shynkaruk O. M., Fedorchenko A. V. (2015) Analiz dosvidu stvorennja ta vykorystannja integhrovanykh telekomunikacijnykh system «Ghart» v Derzhavnij prykordonnij sluzhbi Ukrajiny [Analysis of the experience of creation and use of integrated telecommunication systems «Hart» in the State Border Service of Ukraine]. Zbirnyk naukovykh pracj, no. 2 (64), pp. 221-233. (in Ukrainian)

12. Pro zatverdzhennja Instrukciji pro porjadok ocinky informaciji za metodom 4kh4 : nakaz Administraciji Derzhavnoji prykordonnoji sluzhby Ukrajiny vid 19.01.08 \# 44. Kyjiv: ADPSU, 2008. 28 s. (in Ukrainian)

13. Ghorodnov V. P. Karatajev R. Gh., Kyrylenko V. A. (2009) Modelj vyznachennja stupenja vidpovidnosti ob'jekta uvaghy danym pro potencijnogho porushnyka $\mathrm{v}$ punktakh propusku cherez derzhavnyj kordon [Model for determining the degree of compliance of the object of attention to the information about the potential offender at the border crossing points]. Zbirnyk naukovykh pracj, no. 46. pp. 18-23. (in Ukrainian)

14. Medvedjev M. Gh., Pashhenko I. O. (2008) Teorija jmovirnostej ta matematychna statystyka [Probability theory and mathematical statistics]. Kiev : «Lira-K», 536 p. (in Ukrainian)

\section{Information about the author: Oleh Shynkaruk,}

Doctor of Technical Sciences, professor, rector, Bohdan Khmelnytskyi National Academy of the State Border Guard Service of Ukraine 46 Shevchenka str., Khmelnitskyi, 29007, Ukraine

ORCID ID: orcid.org/0000-0003-4499-8282 


\section{METHODOLOGICAL APPARATUS FOR MONITORING MOVING OBJECTS AT THE STATE BORDER BY A RADAR STATION}

\section{Yuliia Babii}

\section{INTRODUCTION}

According to the Law of Ukraine «On national security of Ukraine», the State Border Guard Service of Ukraine is a part of the military organization of the state, which according to its mandated functions counteracts real and potential threats to national security of Ukraine on the state border. The existing bifurcation of threats to the national security of the state, which is also implemented in the border guard sphere, reveals the need to improve the forms and methods of operational activity, weapons and military equipment, including the expansion of the functional capabilities of technical means of border protection.

The State target law enforcement program «Arrangement and reconstruction of the state border» for the period till 2020, concept documents for the development of engineering-technical equipment of the state border, which were adopted in 2015-2016 specify equipment of the border guard units with modern weapons and military equipment, which should ensure adequate monitoring of mobile objects at the state border of Ukraine. At the same time, the implementation of these and other programs reveal the need for a scientific research for conceptual approaches to monitoring, the formation of general requirements for technical means of border protection, improving the efficiency of recognition of moving objects on the state border of Ukraine.

Long-term underfunding of engineering and technical support, nonalternative use of various funds received for material and technical assistance-significantly slowed down scientific research on the choice of promising technical means of protection, justification of requirements for them. This led, in fact, to the uncertainty of the general vision in the equipment of the border.

This requires the development of a methodological apparatus in the theory of radar as a theoretical basis for the justification of effective monitoring of mobile objects on the state border in order, first of all, to automatically recognize the offender.

The task of monitoring mobile objects on the land border of Ukraine is to identify and recognize the offender against the background of interfering factors. The arrival of new radar samples requires further research in the 
selected area. Therefore, the choice of the observation position, the location of radar stations is important to ensure the continuity of observation in space and time, which requires an assessment of the impact of various factors on the range of their detection, which is an integral part of the surveillance system on the river and land areas of the border.

These information processes are hierarchical in terms of the sequence of their execution. The results of the analysis of information processing methods used in border protection radar stations allow us to note the lack of efficiency of primary processing of radar information, the lack of use of secondary and tertiary processing, which are quite complex processes in algorithmization. That is why it seems appropriate, first of all, to develop methods of secondary processing of radar information and, in the future, primary, which will increase the effectiveness of radar monitoring of mobile objects on the land border of Ukraine.

The main indicators that make it possible to distinguish the offender against the background of interference during primary processing are the effective reflecting surface, the speed and direction of movement of mobile objects relative to radar stations. These indicators are informative for radar stations of various purposes. The peculiarity of the evaluation of the effective reflecting surface and the speed of movement of mobile objects by the radar station is that the range of variation of these parameters largely overlaps for the offender and interference from large domestic and wild animals and from vegetation fluctuations. Therefore, the initial indicators of primary processing - the coordinates of the mobile object and the time of their receipt can relate to the offender, and to the interference.

\section{Analysis of the latest research and publications that initiated the solution of this problem and on which the author relies}

The main indicators that allow to recognize the offender against the background of interference during primary processing is the effective reflecting surface, the speed and direction of movement of the mobile object relative to the radar station. These indicators are informative for radar stations of various purposes.

The peculiarity of the evaluation of the effective reflecting surface and the speed of movement of mobile objects by the radar station is that the range of variation of these parameters largely overlaps for the offender and interference from large domestic and wild animals and from vegetation fluctuations.

Therefore, the initial indicators of primary processing - the coordinates of the mobile object and the time of their receipt can relate to the offender, and to the interference. 
In operating radar stations, the recognition of humans and animals is carried out by the energy method, provided that the Doppler shift of the signal frequency lies in a certain range, and the duration of its influence is not less than the specified value. Thus, the principle of operation of radar stations is based on the registration by the receiver of changes in the «interference pattern» of the electromagnetic field of a moving object in the detection zone.

When making a decision about the presence of an offender, an algorithm is used for the sequential evaluation of three features, namely:

- the frequency of the signal depending on the radial velocity of the object (carried out by the filter);

- the duration of the signal, which depends on the time of crossing the detection zone by the object (performed by the integrator);

- the amplitude of the signal, depending on the size of the moving object.

Due to the fact that many animals for speed and size not different from that of a human, the method of deciding whether the object has the fundamental ability to distinguish between human and animal. This disadvantage is inherent in all Doppler detection tools and leads to a high level of false alarms when operating these tools in places with frequent occurrence.

Thus, the disadvantage of such signal processing is low noise immunity when an animal appears in the detection zone, if its size and speed of movement can be compared with the size and speed of human movement.

To improve the effectiveness of radar stations when animals appear in the detection zone, the study proposes to apply ${ }^{1}$ a number of distinctive features. The increase is achieved by forming a vector of features in signal processing, that have more pronounced differences between humans and animals, and the use of a decision model.

\section{Presentation of the main research material}

When an object moves in the detection zone, the signal reflected from it is modulated in all parameters due to the geometric features of the object structure and the typical method of movement for this class of objects. New informative features based on the difference between human and animal movement play a crucial role in improving noise immunity.

The model of a centimeter-range radar signal creation is based on the radar equation and the description of the Doppler effect, taking into account

\footnotetext{
${ }^{1}$ Onufriev N. V., Stepanov E. A., Rusakov V. Yu. (2017) Radio wave Doppler detector. RF patent [Radiovolnovoy doplerovsky obnaruzhitel. Patent RF]. Moscow, pp. 6-11. (in Russian)
} 
that the object of detection is a complex target and is a set of elementary reflectors (elements):

$$
E_{\partial}(t)=K_{\partial} \sum_{j} K\left(\alpha_{j}(t)\right) \cdot \frac{U_{0} \lambda}{D_{j}^{2}(t)} \cdot \cos \left(\frac{4 \pi V_{j}(t) \Delta t_{j}(t)}{\lambda}\right) \cdot \sqrt{\sigma_{j}(t)},
$$

where $E_{\partial}(t)$ is the output voltage of the phase detector, V;

$K_{\partial}$ - coefficient of proportionality depending on the characteristics of the receiver;

$K\left(\alpha_{j}(t)\right.$ - coefficient of proportionality, which depends on the angle $\alpha$ between the axis of the directivity diagram of the antenna and the direction to the j-element of the movable object;

$U_{0}$ - the level of the probing signal, $\mathrm{V}$;

$\lambda$ - the wavelength of the probing signal, $\mathrm{m}$;

$D_{j}^{2}(t)$ - the distance from the radar station to the $\mathrm{j}$-th element of the mobile object, m;

$V_{j}(t)$ - radial velocity of the j-th element of a moving object, $\mathrm{m} / \mathrm{s}$;

$\Delta t_{j}(t)$ - the time for which the wave front passes from the radar station to the $\mathrm{j}$-th element of the mobile object and back, $\mathrm{s}$;

$\sigma_{j}(t)$ - effective scattering surface of the $\mathrm{j}$-th element of a mobile object, $\left[\mathrm{m}^{2}\right]$;

- number of the moving object element.

To improve the efficiency of recognition when a disturbance appears in the detection zone, it is proposed to apply a number of distinctive features in the current research, which are estimates of specific parameters of the Doppler signal that characterize the properties of the detected mobile object:

1. Man and interference differ in the speed variation of the moving parts. Human walking is a series of rhythmic and alternating movements of the limbs and body that lead to the forward movement of the center of gravity. Since, the speed of limb movements with different speed movements of the body, and the frequency of reflected signals differ from the frequency of the main peak, which leads to the expansion of the frequency spectrum of the signal from the person.

A sign for evaluating this difference is the relative broadband spectrum of the signal, as the ratio of the frequency of the maximum spectrum of the Doppler signal to its width (broadband signal): 
The attribute is calculated according to the formula:

$$
O_{1}=\frac{f_{\text {гл.max }}}{f_{\max }-f_{\min }}
$$

where is the main maximum of the amplitude-frequency spectrum of the Doppler signal, Fig. 1;

- maximum frequency of the signal spectrum by level;

- minimum frequency of the signal spectrum by level.

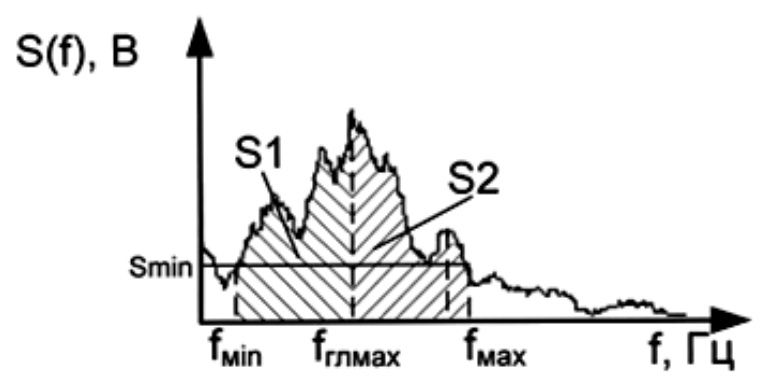

Fig. 1. Amplitude-frequency response of a moving object signal

Obviously, a person is characterized by a large broadband.

If $\mathrm{O}_{1}>0,7$, then the classifier variable $\mathrm{h}_{1}=+1$, if less, then -1 .

2. A person is distinguished by the ratio of the size of the body parts, moving at a greater and lower speed of the body. Since a person makes additional balancing movements with his hands for a uniform forward movement, therefore, in certain phases of the step, two limbs move faster than the body, and the other two limbs are slower. Since the animal does not need to make balancing movements for walking, when moving at a pace, only one limb moves faster than the trunk, and the other limbs are used as a support.

As a rule, the symmetry of the frequency spectrum of the Doppler signal is used to evaluate this difference. The attribute is calculated by the formula: 


$$
\begin{gathered}
O_{2}=\frac{\int_{\text {гл.max }}^{f_{\min }} S(f) d f}{f_{\max } S(f) d f} \\
f_{\text {гл.max }} \\
\text { where } \frac{f_{\text {гл.max }}^{f_{\min }} S(f) d f}{f_{\max } S(f) d f} \\
f_{\text {гл.max }}
\end{gathered}
$$

is the area $S_{1}$, Fig. 1, under the curve of the amplitude-frequency spectrum of the Doppler signal in the section $f_{\min }$ from $f_{\text {гл.max }}$;

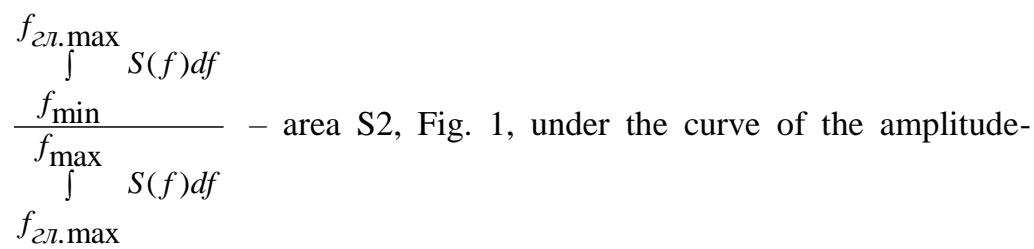
frequency spectrum of the Doppler signal in the section from to $f_{\text {гл.max }} f_{\max }$.

If $\mathrm{O}_{2}=1$, then change the classifier $\mathrm{h}_{1}=+1$, if $\mathrm{O}_{2}>1$, then $\mathrm{h}_{2}=-1$.

It should be noted that the considered features require analysis of the spectral components of the reflected signal from the moving parts of the body of a moving object. As noted $\mathrm{in}^{2}$ it is not possible to identify a particular local maximum with the signal reflected from the corresponding mobile object, since it is impossible to measure the instantaneous frequency of the signal from each mobile object and, consequently, to determine its instantaneous coordinate.

However, if we consider that each local maximum is formed as a result of the superposition of signals from the limbs of a moving object, then by summing the relative frequencies of local maxima, we can «pull out» information about the vector sum of the instantaneous dynamic coordinates of the moving object.

${ }^{2}$ Kryukov N. I. (2015) Radiolokatsionnyie sredstva ohrannogo monitoringa. Teoriya i praktika postroeniya : monografiya [Radar security monitoring equipment. Theory and practice of construction : monograph]. Moscow, 345 p. (in Russian) 
The value of the vector sum of the dynamic coordinates of the limbs of a mobile object is prone to periodic fluctuations, and the average value of these fluctuations is a constant that characterizes the movement of the mobile object.

So, to use these two features to classify a moving object is possible under the condition of a long accumulation of reflected signals from a moving object, averaging them and performing analysis.

Radar stations of optical-electronic surveillance operate in the mode of scanning a specific sector exposure of the same area a few tens of seconds, which allows us to recommend the introduction of methods of increase of efficiency of recognition of moving objects data characteristics only if the mode of target acquisition.

In the future, a weighted convolution of the surest signs (two signs) according to the classification indicator is carried out, consisting of a set of $\mathbf{j}$ (h can take the value «1» or «+1») solutions and weight coefficients $\alpha_{k}$ :

$$
M=\operatorname{sign}\left[\sum_{k}^{j} \alpha_{k} h_{k}\right]
$$

where is the result sign;

- number of solutions;

- an indicator classification.

As a result of the weighted convolution, a decision is made about the class of the detected object, namely: «plus» - the intruder, «minus» - the interference.

Improving noise immunity is achieved by making changes in signal processing - the use of recognition based on the formation of the feature vector.

To improve the efficiency of recognition when a disturbance appears in the detection zone, it is proposed to apply a number of distinctive features in the current research, which are estimates of specific parameters of the Doppler signal that characterize the properties of the detected mobile object:

- variation of speeds of moving parts of the human body and the body of an animal;

- the ratio of the size of the parts moving at a speed greater or less than the speed of the body.

It is possible to use these two features to recognize the offender among moving objects under the condition of long-term accumulation of reflected signals from moving objects, averaging them and analysis. 
Radar stations of optical-electronic surveillance operate in the mode of scanning a specific sector exposure of the same area a few tens of seconds, which allows us to recommend the introduction of methods of increase of efficiency of recognition of moving objects data characteristics only if the mode of target acquisition.

Increasing the number of recognition features will further improve the effectiveness of recognition in the mobile object of the offender. Therefore, the considered signs of primary signal processing should be supplemented with secondary processing of information, the indicators of which are specific and depend on the purpose of the radar station.

The main indicators that allow you to distinguish the offender against the background of interference during secondary processing, is the change in the coordinates of the moving object in time and space.

It is the change of coordinates, and not the coordinates themselves, significantly distinguishing the offender as a mobile object that purposefully crosses the land border.

This will allow you to recognize the offender, identify the facts of the offender's use of a known route and the emergence of new ones. It is important that the emergence of new routes can be detected in real time with the use of radar stations.

In general for secondary processing of radar information when monitoring a moving object on the land border it is necessary to process such information:

1) a priori data of coordinates of possible routes of movement of the offender in a sensitive zone of radar stations;

2) a priori data on the location of radar stations;

3) a posteriori data of primary processing of radar information about time and coordinates of the detected mobile object;

4) a posteriori data of secondary processing of radar information about the trajectory of movement of the identified offender.

The first three types of information are taken into account in the models of border security monitoring developed by Russian scientists ${ }^{3,4,5,6,7}$. In the

${ }^{3}$ Myroshnychenko V. A. (2005) Geoinformatsionnyiy metod analiza predstavleniya i territorialnoy obstanovki $\mathrm{v}$ sisteme monitoringa ohrannogo [Geoinformation method of representation and analysis of the territorial situation in the security monitoring system]. SanktPeterburh, p. 184 (in Russian)

${ }^{4}$ Ryabets Y. A. (2006) Matematiko-geoinformatsionnaya model logiko-veroyatnostnoy otsenki effektivnosti territorialno-raspredelennoy sistemyi ohrannogo monitoringa [A mathematical-geoinformation model of the logical and probabilistic evaluation of the effectiveness of a territoriallydistributed security monitoring system]. Moscow, pp. 97-106. (in Russian)

5 Babii Yu. O. (2017) Metod vtorynnoji obrobky radiolokacijnoji informaciji pry monitorynghu rukhomogho ob'jektu na sukhoputnomu kordoni Ukrajiny [The method of secondary processing of radar information during monitoring of a moving object on the land border of Ukraine]. Nauka i tekhnika povitrjanykh syl Zbrojnykh syl Ukrajiny. Kharkiv, no. 3(28). pp. 55-62. (in Ukraine) 
Ukrainian scientific works, the first type of information is taken into account in the methodology for determining the likely location of the ${ }^{8}$ offender, the basis and development of secondary processing of radar information is presented in the research ${ }^{9,10,11}$.

In the current method, it is possible to form a graph of probable routes of the offender in the controlled area. Differentiation of geo-information structure of the controlled area, subjectivity in determining the coordinates of the points through which the movement of the offender is possible indicate a very significant approximation of the true trajectories of possible routes of movement.

The emergence of a new unknown route of movement, the deviation of the trajectory of the offender from the known routes-does not allow to fully provide effective conditions for the detention of the offender using the provisions of the current methodology.

${ }^{6}$ Babii Yu. O., Lysyj M. I. (2018) Metodyka pidvyshhennja dostovirnosti rozpiznavannja pravoporushnyka pry monitorynghu rukhomogho ob'jekta radiolokacijnoju stancijeju. Pidsumky rozvytku naukovoji dumky [The technique of increasing the accuracy of the recognition of the offender when monitoring a moving object by a radar station]. Zb. nauk. pracj « $\Lambda O G h O \Sigma$ : materialy Mizhnarodnoji naukovo-praktychnoji konferenciji, Vinnycja : Vyd-vo «Jevropejsjka naukova platforma», vol. 1, pp. 14-16. (in Ukraine)

${ }^{7}$ Babii Yu. O., Lysyj M. I. (2018) Alghorytm rozpiznavannja metodyky pidvyshhennja efektyvnosti rozpiznavannja pravoporushnyka pry monitorynghu rukhomogho ob'jekta radiolokacijnoju stancijeju [Algorithm recognition algorithm for enhancing the efficiency of offender recognition when monitoring a moving object by a radar station]. Rolj innovacij $v$ transformaciji obrazu suchasnoji nauky : materialy 2-oji Mizhnar. naukovo-prakt. konf. (m. Kyjiv, 28-29 ghrudnja 2018 r.). Kyjiv : Vyd-vo In-tu innovacijnoji osvity, pp. 99-100. (in Ukraine)

${ }^{8}$ Horodnov V. P. (2008) Model vyznachennia ymovirnykh marshrutiv rukhu porushnykiv kordonu poza punktamy propusku cherez derzhavnyi kordon [A model for determining possible routes for violators crossing the border outside the border crossing points]. Khmelnytsky, pp. 11-17. (in Ukraine)

${ }^{9}$ Snitsarenko P. M. (2016) Teoriia ozbroiennia. Naukovo-tekhnichni problem ta zavdannia: monohrafiia: Tekhnichni zasoby. Viiskovi systemy dystantsiinoho monitorynhu navkolyshnoho prostoru shchodo rukhomykh obiektiv: metodolohichni aspekty obgruntuvannia vymoh [The theory of weapons. Scientific and technical problems and tasks: monograph: technical means. Military systems of remote monitoring of the surrounding space in relation to moving objects: methodological aspects of substantiation of requirements]. Kiev, 480 p. (in Ukraine)

${ }^{10}$ Hryzo A. A. (2017) Udoskonalennia vtorynnoi obrobky radiolokatsiinoi informatsii v RLS [Improvement of the secondary processing of radar information in the radar]. Kharkiv, pp. 78-81. (in Ukraine)

${ }^{11}$ Kovtunov A. L. (2013) Metodyi vtorichnoy obrabotki radiolokatsionnoy informatsii v obzornyih RLS, ispolzuyuschih polyarnuyu sistemu koordinat $\mathrm{s}$ primeneniem sverhshirokopolosnyih signalov [Methods of secondary processing of radar information in survey radars using a polar coordinate system using ultra-wideband signals]. Kharkiv, pp. 74-78. (in Ukraine) 
It is important to recognize the route of the offender on the basis of the identified features of changing the trajectory of the offender and interference, which are put in the development of a method of secondary processing of radar information when monitoring a mobile object on the land border of Ukraine.

The relevance of the development of this technique to improve the efficiency of recognition of the offender of the state border when monitoring mobile objects by radar is due to the fact that many years of experience in the operation of radar means of border protection indicates that the greatest flow of false alarms comes from the movement of animals.

Just a few of these triggers per shift, so that the outfit refused to act correctly on the alarm and disdained the technical means of protection.

The technique is designed to recognize the movement of the offender in the area of the radar station taking into account the data of the secondary processing of radar information and is based on the supplemented features of the classification of the mobile object.

The initial data for the calculations are as follows:

- time and coordinates of the detected moving object;

- a database of possible routes of movement of the offender;

The structure of the methodology has the following components:

- determination of the indicator and criterion for monotonicity of changes in at least one of the coordinates of the moving object.

- development of an algorithm for secondary processing of radar information when monitoring mobile objects on the land border.

The method is characterized by the expansion of the set of signs of recognition of the offender and a sign of purposefulness of the trajectory of the mobile object. This allowed, according to the developed indicator and criterion of purposefulness, to recognize the offender against the background of interference, for example, the movement of animals.

Let's make an assumption:

- the offender purposefully crosses the border.

- the offender has no information about the operation of the radar station.

The first assumption is based on the very essence of illegal activity, as conscious actions in the space-time field. The basis for the second assumption is the masking effect of the radar station and the confidentiality of information.

Then, in General, the trajectory of a moving object that moves through the sensitive zone will be classified as:

- chaotic (the course of movement changes chaotically);

- purposeful (the course of movement changes in a certain direction); 
- defined (road section).

It is characteristic that for a chaotic trajectory there is a significant excess of the length of the path traversed by a mobile object from the initial and to the final point of the trajectory for the distance between them, which is a classifying feature of determining the trajectory of animals.

Let us assume that the movement of animals or the oscillation of vegetation is characterized, to a large extent, by randomness of direction, not purposefulness. Let us assume that the movement of animals or the oscillation of vegetation is characterized, to a large extent, by randomness of direction, not purposefulness. This makes it possible to form an indicator of purposefulness:

$$
M=1-\frac{L_{1 N}}{\sum_{i=1}^{N} L_{i}},
$$

where $M$ is the indicator of purposefulness of the trajectory of a moving object;

$N$ - number of the last location point of the mobile object measured by the radar station;

$L_{i}$ - the length of the trajectory section between two successively measured points of the moving object location;

$L_{1 N}$ - the length of the trajectory section between the first and last points of the moving object location.

The threshold of the decision making will be the cases when the trajectory length exceeds not more than twice the distance from the beginning of detection and to the end point of detection of the moving object of the radar station. Then the criterion for moving the offender, recognizing it against the background of interference is inequality:

$$
M \leq 0,5
$$

Advanced technique intended to detect the movement of the offender in range of a radar station and is based on augmented considered the classification of the movable object. The main stages are presented in the form of an algorithm (figure 2). The more signs of recognition of the offender's movement from the interference, the more effective the technique. 


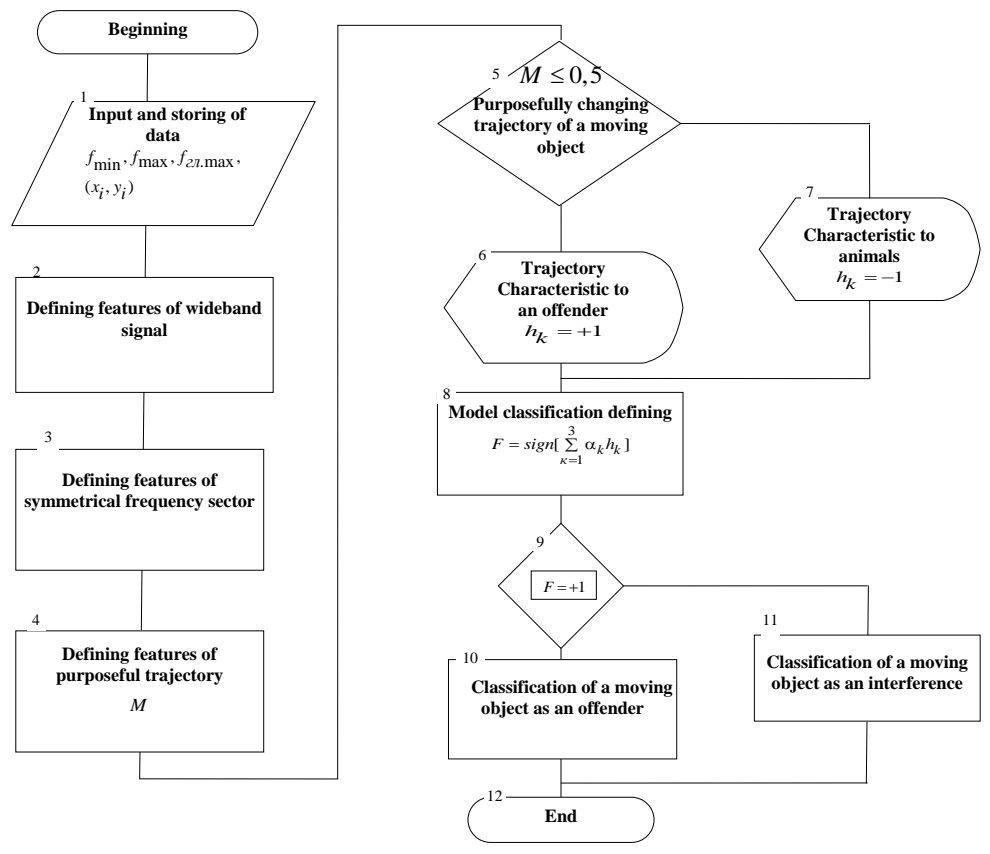

Fig. 2. Algorithm for improving the effectiveness of offender recognition when monitoring a moving object by a radar station

The first blocks of the algorithm include the use of the existing distinctive signs which may be supplemented by a new classification characteristic of the trajectory of movement of the movable object - for the targeted trajectory is substantially increased path length of a moving object from the initial to the final point of the trajectory for the distance between them, which is a classifying feature of the definition of the trajectory interference. This made it possible to recognize the offender's movements against the background of interference (figure 3). 


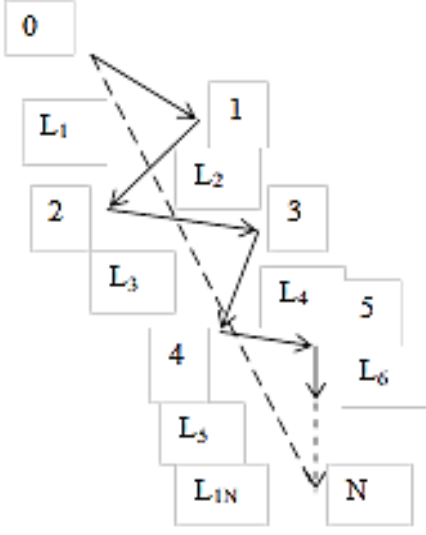

a)

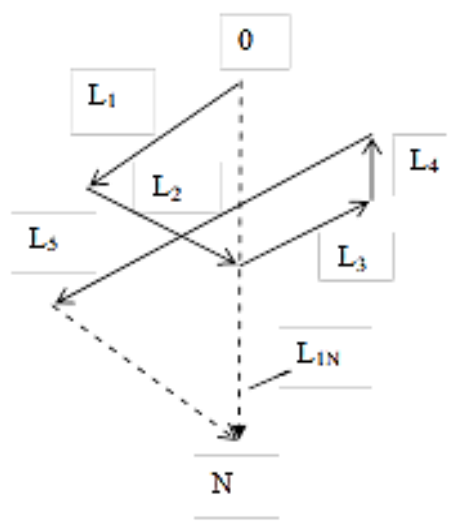

b)

\section{Fig. 3. Trajectory of a moving object: a) human; b) interference}

The developed algorithm reflects the main stages of the method and provides:

- calculation of recognition features by primary processing of the radar signal, blocks 2, 3 (expressions 2; 3);

- determination of the purposefulness of the trajectory of a mobile object according to the developed indicator and criterion for secondary information processing, blocks 4, 5;

- calculation of the indicator and criterion of recognition of the offender by the current method, blocks 8,9 (expression 4);

- issuing an alarm when an offender is detected, block 10.

The developed algorithm allows you to recognize a single offender against the background of interference from the movement of the animal.

Models and new technical solutions for tertiary information processing can be used to assess the trajectory of a group of offenders and to highlight the impact of interference.

In the algorithm of the method of increasing the efficiency of recognition of the offender when monitoring mobile objects by radar, the first three blocks are carried out according to the current method described in the work of Kryukov N. I. and provides spectral analysis of the Doppler signal reflected from various parts of the body of the mobile object. The remaining blocks describe the application of the proposed sign of purposefulness of the trajectory of a moving object. 


\section{CONCLUSIONS}

Thus, we note the following:

the set of signs of recognition of the offender by the radar station is expanded, the criterion of purposefulness is defined;

the trajectory of a movable object is classified as chaotic, purposeful and determined, in accordance with the established features of the classification:

a) if there is not a monotonous change in at least one $x_{i}, y_{i}$ coordinate of the object, which is a sign of classification of moving interference, the trajectory is referred to as chaotic or definite, the movement on it is not purposeful, in this case, basically moving object is an interference;

b) the next sign of classification is the coincidence of the trajectory of the moving object with the possible route of the offender's movement through the sensitive zone, such a trajectory is classified as defined, and the moving object is taken for the offender;

c) if the trajectory is not classified as chaotic or of a certain type, it is considered purposeful.

\section{SUMMARY}

The technique of improving the efficiency of border offender (moving object) detection during radar monitoring on the basis of secondary information processing is made in the article.

An algorithm for the method of increasing the efficiency of border offender recognition during radar monitoring has been developed, which further allowed y allowed to identify a single moving object against the background of noise.

The method of increasing the effectiveness of recognition of the offender when monitoring mobile objects by radar has been improved. The method is characterized by the expansion of the set of signs of recognition of the offender and a sign of purposefulness of the trajectory of the mobile object. This made it possible, according to the developed indicator and criterion of purposefulness of the trajectory of a mobile object, to increase the efficiency of recognition of the offender against the background of interference.

The reliability of the improved methodology was confirmed by the result of an experiment conducted in the Podolsk border detachment with the use of radar stations of the Optical-electronic observation system. The efficiency of radar recognition of the offender against the background of interference was increased by 20-24\% when referring to the trajectory of the moving object to a targeted view. 


\section{REFERENCES}

1. Onufriev N. V., Stepanov E. A., Rusakov V. Yu. (2017) Radio wave Doppler detector. RF patent [Radiovolnovoy doplerovsky obnaruzhitel. Patent RF]. Moscow, pp. 6-11. (in Russian)

2. Kryukov N. I. (2015) Radiolokatsionnyie sredstva ohrannogo monitoringa. Teoriya i praktika postroeniya. Monografiya [Radar security monitoring equipment. Theory and practice of construction. Monograph]. Moscow, 345 p. (in Russian)

3. Myroshnychenko V. A. (2005) Geoinformatsionnyiy metod analiza predstavleniya i territorialnoy obstanovki $\mathrm{v}$ sisteme monitoringa ohrannogo [Geoinformation method of representation and analysis of the territorial situation in the security monitoring system]. Sankt-Peterburh, p. 184 (in Russian)

4. Ryabets Y. A. (2006) Matematiko-geoinformatsionnaya model logiko-veroyatnostnoy otsenki effektivnosti territorialno-raspredelennoy sistemyi ohrannogo monitoringa [A mathematical-geo-information model of the logical and probabilistic evaluation of the effectiveness of a territoriallydistributed security monitoring system]. Moscow, pp. 97-106. (in Russian)

5. Babii Yu. O. (2017) Metod vtorynnoji obrobky radiolokacijnoji informaciji pry monitorynghu rukhomogho ob'jektu na sukhoputnomu kordoni Ukrajiny [The method of secondary processing of radar information during monitoring of a moving object on the land border of Ukraine]. Nauka $i$ tekhnika povitrjanykh syl Zbrojnykh syl Ukrajiny. Kharkiv, no. 3(28). pp. 55-62. (in Ukraine)

6. Babii Yu. O., Lysyj M. I. (2018) Metodyka pidvyshhennja dostovirnosti rozpiznavannja pravoporushnyka pry monitorynghu rukhomogho ob'jekta radiolokacijnoju stancijeju. Pidsumky rozvytku naukovoji dumky [The technique of increasing the accuracy of the recognition of the offender when monitoring a moving object by a radar station]. Zb. nauk. pracj " $\Lambda O G h O \Sigma »$ : materialy Mizhnarodnoji naukovopraktychnoji konferenciji, Vinnycja : Vyd-vo «Jevropejsjka naukova platforma», vol. 1, pp. 14-16. (in Ukraine)

7. Babii Yu. O., Lysyj M. I. (2018) Alghorytm rozpiznavannja metodyky pidvyshhennja efektyvnosti rozpiznavannja pravoporushnyka pry monitorynghu rukhomogho ob'jekta radiolokacijnoju stancijeju [Algorithm recognition algorithm for enhancing the efficiency of offender recognition when monitoring a moving object by a radar station]. Rolj innovacij $v$ transformaciji obrazu suchasnoji nauky : materialy 2-oji Mizhnar. naukovoprakt. konf. (m. Kyjiv, 28-29 ghrudnja 2018 r.). Kyjiv : Vyd-vo In-tu innovacijnoji osvity, pp. 99-100. (in Ukraine)

8. Horodnov V. P. (2008) Model vyznachennia ymovirnykh marshrutiv rukhu porushnykiv kordonu poza punktamy propusku cherez derzhavnyi 
kordon [A model for determining possible routes for violators crossing the border outside the border crossing points]. Khmelnytsky, pp. 11-17. (in Ukraine)

9. Snitsarenko P. M. (2016) Teoriia ozbroiennia. Naukovo-tekhnichni problem ta zavdannia: monohrafiia: Tekhnichni zasoby. Viiskovi systemy dystantsiinoho monitorynhu navkolyshnoho prostoru shchodo rukhomykh obiektiv: metodolohichni aspekty obgruntuvannia vymoh [The theory of weapons. Scientific and technical problems and tasks: monograph: technical means. Military systems of remote monitoring of the surrounding space in relation to moving objects: methodological aspects of substantiation of requirements]. Kiev, 480p. (in Ukraine)

10. Hryzo A. A. (2017) Udoskonalennia vtorynnoi obrobky radiolokatsiinoi informatsii $\mathrm{v}$ RLS [Improvement of the secondary processing of radar information in the radar]. Kharkiv, pp. 78-81. (in Ukraine)

11. Kovtunov A. L. (2013) Methods of secondary processing of radar information in survey radars using a polar coordinate system using ultrawideband signals [Metodyi vtorichnoy obrabotki radiolokatsionnoy informatsii v obzornyih RLS, ispolzuyuschih polyarnuyu sistemu koordinat $\mathrm{s}$ primeneniem sverhshirokopolosnyih signalov]. Kharkiv, pp. 74-78. (in Ukraine)

\section{Information about the author:} Yuliia Babii, Doctor of Technical Sciences, chief of doctorate, Bohdan Khmelnytsky National Academy of the State Border Guard Service of Ukraine 46 Shevchenko str., Khmelnitskyi, 29007, Ukraine ORCID ID: orcid.org/0000-0001-7310-8715 


\section{IRREGULAR MIGRATION AS AN OBJECT OF RESEARCH IN THE CONTEXT OF FINDING WAYS TO IMPROVE THE EFFECTIVENESS OF ORGANIZING COUNTERACTION IN THE AREA OF RESPONSIBILITY OF CHOP BORDER GUARD DETACHMENT OUTSIDE BORDER CROSSING POINTS}

\section{Volodymyr Kyrylenko}

\section{INTRODUCTION}

Protection of the state border ${ }^{1}$ by Chop Border Guard Detachment is performed at the border sector with the following types of area: mountainous terrain, which is characterized by an acute change of weather during the day, mountain collapses, avalanches, landslides; with water obstacles; difficult to access areas; sparsely populated; with a poorly developed road network; carrying out seasonal work in the border zone and controlled border areas. The conditions inherent in the area of responsibility of Chop Border Guard Detachment can both facilitate and hinder the actions of offenders, and the actions of the forces of the Border Guard Service Divisions in performing tasks for the protection of the state border, which affects the effectiveness of the tasks of operational and service activity by Border Guard units.

The existing scientific and methodological apparatus of operationaltactical calculations for the organization of operational-service activity (OSA) is developed for the conditions of service for specific areas of the state border (wooded area, forest, river, etc.) and, in general, for the organization's operational activities on the sector of a typical border guard detachment. That means it does not take into account the specifics of a particular border patrol, only internal and external threats and risks (in general, illegal activities are associated with illegal migration, smuggling, at checkpoints and outside them) that are inherent in this region of Ukraine. This reveals the need to find real ways to improve the effectiveness of the organization of combating illegal migration in the area of responsibility of Chop Border Guard Detachment outside the checkpoints.

1 Tematychnyy analiz ryzykiv: vyznachennya zahroz ta ryzykiv na dilyantsi zahonu $\mathrm{z}$ metoyu vyznachennya zavdan' pidporyadkovanym pidrozdilam na okhoronu derzhavnoho kordonu v 2019 rotsi (2018) [Thematic Risk Analysis: Identifying Threats and Risks at the Detachment Area to Identify Tasks for Subordinate Border Protection Units in 2019]. Chop, p. 26. (in Ukraine) 
Analysis of recent research and publications. A large number of scientific papers (for example ${ }^{2,3,4,5,6,7,8}$ ) have been devoted to the study of evaluating the effectiveness of performing the tasks assigned to border units for OSA during the defined period However, the issues of illegal migration as an object of research in the context of finding ways to improve the effectiveness of the organization of combating illegal migration in the area of responsibility of Chop Border Detachment outside the checkpoints were not considered.

${ }^{2}$ Stratehiya intehrovanoho upravlinnya kordonamy na period do 2025 roku [Elektronuj resurs] Rozporyadzhennya Kabinetu Ministriv Ukrayinu vid 24 lypnya 2019 roku № 687-r. Rezhum dostupu: https://zakon.rada.gov.ua/laws/show/687-2019-\%D1\%80 (data zvernennya: 30.12.2019) [An integrated border management strategy for the period up to 2025: [Electronic Resource] Order of the Cabinet of Ministers of Ukraine No. 687-r as of July 24, 2019, available at: https://zakon.rada.gov.ua/laws/show/687-2019-\%D1\%80].

3 Pro Rishennya Rady natsionalnoyi bezpeky i oborony vid 06 travnya 2015 r. «Pro Stratehiyu natsionalnoyi bezpeky Ukrayiny». Ukaz Prezydenta Ukrayiny vid 06 travnya $2015 \mathrm{r}$. № 287/2015. [Elektronuy resurs] - Rezhy`m dostupu: http://zakon3.rada.gov.ua/laws/show/ n0008525-15 [On the Decision of the National Security and Defense Council as of May 06, 2015 « About the National Security Strategy of Ukraine» Decree of the President of Ukraine as of May 06, 2015, available at: http://zakon3.rada.gov.ua/laws/show/n0008525-15.

4 Zakon Ukrayiny № 661-IV «Pro derzhavnu prukordonnu sluzhbu Ukrayinu» vid 3 kvitnya 2003 roku (Vidomosti Verxovnoyi Radu Ukrayinu, 2003, N 27, st. 2, 20). [Law No. 661-IV of Ukraine On the State Border Service of Ukraine as of April 3, 2003 (The Official Bulletin of the Verkhovna Rada of Ukraine (OBVR)), 2003, 27, Art. 208)]. [in Ukrainian]

5 Mejko O. V. (2014) Metoduka vuznachennya racionalnogo varianta zastosuvannya mobilnux grup okremogo viddilu prukordonnoyi sluzhbu tupy "S" pid chas uskladnennya obstanovku na dilyankax derzhavnogo kordonu [Methods of determining the rational variant of the use of Type $\mathrm{C}$ mobile teams of a separate department of the border service during the aggravation of the situation at the state border sections] Zbirnyk naukovykh prats, Kharkiv : $K N A F U$, No. 4 (41), pp. 153-156. [in Ukrainian]

6 Farion O. B. (2009) Metoduka ocinku efektuvnosti sustemu informacijnogo zabezpechennya viddilu prukordonnoyi sluzhbu tupy «B» [Methods of evaluation of the effectiveness of the system of information support of the Type B department of the border service] Zbirnyk naukovykh prats Natsionalnoi akademii Derzhavnoi prykordonnoi sluzhby Ukrainy im. B. Khmelnytskoho, Khmelnytskyi : NASBSU, no. 49, pp. 97-115. [in Ukrainian]

7 Kovalev D. V. (2017) Algorutm metoduku vuznachennya racionalnogo varianta organizaciyi operatuvno-sluzhbovoyi diyalnosti viddiliv prukordonnoyi sluzhbu tupy "A" $\mathrm{v}$ kontrolnux punktax vyizdu/vyjizdu [Algorithm of methodology of determination of rational variant of organization of operatively-official activity of departments of frontier service as «A» in the markpoints of entrance/of departure]. Zbirnyk naukovykh prats Natsionalnoi akademii Derzhavnoi prykordonnoi sluzhby Ukrainy im. B. Khmelnytskoho, Khmelnytskyi : NASBSU, no. 2(72), pp. 116-125. [in Ukrainian]

${ }^{8}$ Shinkaruk O. M., Mosov S. P., Kirilenko V. A. (2018) Prykordonna bezpeka Ukrayiny: stanovlennya, suchasnyy stan, problemy i perspektyvy: monohrafiya [Border security of Ukraine: formation, current state, problems and prospects: monograph]. Khmelnytsky : $N A S B S U$, p. 187 p. [in Ukrainian] 
The purpose of the article is the reveal the notion of irregular migration and the specific tasks of OSA regarding its counteracting in the area of responsibility of Chop Border Guard Detachment and finding ways to improve it (counteract) efficiency.

\section{Types of encroachments on the integrity of the state border}

World processes in the era of globalization are significantly affected by such a complex socio-economic, legal and political phenomenon as migration - one of the most serious problems of our time, the flows of which have reached such proportions that the governments of different countries cannot ignore this phenomenon ${ }^{9,10,11}$.

According to the analysis of scientific sources, despite certain differences, the concept of migration is defined as relocation, the movement of a population (an individual or groups of people within a country or from one country to another, which is aimed at acquiring resources in new territories and is associated with a temporary or permanent change of residence $^{12,13,14}$.

Types of migration depend on the criteria for its classification, namely:

ways - organized and unorganized;

degree of control - legal and illegal;

territorial characteristics - internal and external;

temporary characteristics - irreversible, temporary, seasonal, nomadic;

relationship to the host country, emigration, immigration, assimilated, transit.

According to the legal basis, migrants are divided into:

legal - who cross international borders legally;

semi legal - arrive legally and change their status);

illegal - cross the state border:

- outside checkpoints;

\footnotetext{
${ }^{9}$ Blazhivsky E. M. (2008) International migration is one of the biggest problems of modern Ukraine. Visn. prokuratu, no. 6. pp. 3-13. [in English]

${ }^{10}$ Rashitov L. R. (2016) Criminological characteristics of crimes in the sphere of illegal migration and their prevention. BULLETIN of the Kazan law Institute of the Ministry of internal Affairs of Russia, no. 1(23), pp. 124-28. (in English)

11 Malinovska O. A. (2018) Migration policy: global context and Ukrainian realities: monograph. Kiev : NISD, 472 p. (in English)

${ }^{12}$ Purygina O. G. (2007) International migration: studies. stipend. Kiev : VC «Academy», 312 p. (in English)

${ }^{13}$ Babiia V. M., Koretsky V. M. (1974) Law dictionary / edited by academics of VSSR Academy of Sciences. Kiev, 844 p. (in English)

${ }^{14}$ Gusarov S. M., Komzuk A. T., Salmanova A. Yu. (2016) Migration law of Ukraine : textbook. Kharkiv : advertising House, 296 p. (in English)
} 
- through checkpoints using forged (invalid) documents;

- through checkpoints with concealment in the design features of vehicles, in cargo, using other ways to avoid border control) ${ }^{1516}$.

Today there is no single approach to defining the concept of «irregular (illegal) migration» as opposed to the concept of «Illegal migrant».

According to paragraph 14, paragraph 1 of article 1 of the Law of Ukraine «On the legal status of foreigners and stateless persons», an illegal migrant is a foreigner or a stateless person who crossed the state border outside checkpoints or at checkpoints, but with the avoidance of border control and did not immediately apply for refugee status or asylum in Ukraine, as well as a foreigner or a stateless person who legally arrived in Ukraine, but after a certain period of stay lost their grounds for further stay and evade departure from Ukraine ${ }^{17}$.

The term «illegal migration» is a generally accepted concept for determining the movement of people across state borders in violation of legal norms. The terms «illegal migration «and» irregular migration» are used as synonyms. However, this term is most often used in official documents, while the concept of «illegal migration» is characteristic of scientific research and journalistic texts ${ }^{18}$.

In contrast to international law, the concept of «illegal» or «irregular» migration prevails in national laws and regulations of the EU, which reflects the priority of the state's interests. According to the definition of the International organization for migration, these terms are identified with the concept of unregulated migration. Recently, the terms «managed» and «unmanaged» migration are increasingly used in publicistic works, scientific research, and international speeches, but their definition is not given ${ }^{19}$.

Illegal (irregular) migration is illegal movement across the state border, that is, outside checkpoints or hiding from border and customs control, using false documents, a visa (or without a visa), independently or with the help of

${ }^{15}$ Kuzmenko O. V. (2000) Administrative and legal counteraction to illegal migration in Ukraine: dis. ... Cand. Law. Sciences. Kiev, 196 p. (in Ukrainian)

${ }^{16}$ Mosiondz S. O. (2005) Administrative and legal bases of the state migration policy in Ukraine. Kyiev : Master of the twenty-first century, 206 p. (in Ukrainian)

${ }^{17}$ On the legal status of foreigners and stateless persons. Law of Ukraine No. 3773-VI of September 22, 2011 (Vidomosti Verkhovnoi Rady Ukrainy (VVR), 2012, No. 19-20, art. 179). Retrieved from: https://zakon.rada.gov.ua/laws/show/3773-17. (in Ukrainian)

${ }^{18}$ Binkovskyi O. A., Zalozh V. V., Dovgan V. I. (2016) Mechanisms for countering irregular migration in Ukraine. Eurasian Academic Research Journal, no. 2(02), pp. 14-22. (in English)

19 Shevchenko O. M. (2010) Udoskonalennja mekhanizmiv derzhavnogho upravlinnja mighracijnymy procesamy [Improving the mechanisms of state management of migration processes]. Donetsk. 2010. 25 p. (in Ukrainian) 
third parties, as well as residence on the territory of the country without the proper permission of the competent state authorities ${ }^{20,21}$.

We support the point of view of those scientists who believe that illegal migration is crossing the borders of a state for a purpose or in a manner that violates legislation, including international law ${ }^{22}$.

\section{Illegal migration as a type of organized crime that encroaches on the inviolability of the state border}

Chop border guard detachment of the Western Regional Directorate of the State Border Guard Service protects the state border within three controlled border areas (Velyky Bereznyi, Perechyn, Uzhgorod) with three EU States and a total length of $149.4 \mathrm{~km}$ : Poland $(30.9 \mathrm{~km})$, Slovakia $(97.85 \mathrm{~km})$ and Hungary $(20.65 \mathrm{~km})$.

Of these, the land sector is $132 \mathrm{~km} 600$ meters (mountain $83 \mathrm{~km}$ ), along the rivers- $16 \mathrm{~km} 800$ meters. The state border mostly (57\%) passes through mountainous, wooded, heavily rugged terrain. The main units of the state border protection are: 3 divisions of the border service, which includes 16 sections of border guard service of inspectors and the $\langle\mathrm{C} »$ type border service division. Current vulnerabilities of major and minor threats are presented in the table. 1 .

Table 1

\section{Current vulnerabilities of major and minor threats}

\begin{tabular}{|c|c|}
\hline № & Vulnerabilities \\
\hline \multicolumn{2}{|r|}{ I. Vulnerabilities of major threats } \\
\hline 1.1 & $\begin{array}{l}\text { Unstable socio-economic and political situation, local military conflicts and wars in } \\
\text { the countries that are the main sources of illegal migrants, which causes further } \\
\text { activity of the process of illegal migration from the countries of South-East Asia, } \\
\text { North and West Africa, the Middle East, the post-Soviet space, transit through } \\
\text { Ukraine to the EU member States }\end{array}$ \\
\hline 1.2 & Russian military aggression in Eastern Ukraine \\
\hline 1.3 & $\begin{array}{l}\text { Destabilization of the socio-economic and political situation in Ukraine } \\
\text { by pro-Russian forces }\end{array}$ \\
\hline 1.4 & $\begin{array}{l}\text { Significant difference in prices for tobacco products in Ukraine and neighboring } \\
\text { countries }\end{array}$ \\
\hline
\end{tabular}

${ }^{20}$ Zakharchenko M. (2014) Prychyny ta sutnistj javyshha nereghuljarnoji (neleghaljnoji) mighraciji [Reasons and essence of the phenomenon of irregular (illegal) migration]. Customs activity, pp. 262-267. (in Ukrainian)

${ }^{21}$ Mozol A. P. (2002) Kryminologhichni problemy neleghaljnoji mighraciji v Ukrajini [Criminological problems of illegal migration in Ukraine]. Kiev, 212 p. (in Ukrainian)

${ }^{22}$ Ognev T. E. (2017) Nereghuljarna mighracija: kryminaljne pravo ta kryminologhichni aspekty [Irregular migration: criminal law and criminological aspects]. Institute of state and law. V. M. Koretsky, 20 p. (in Ukrainian) 


\begin{tabular}{|c|c|}
\hline № & Vulnerabilities \\
\hline 1.5 & $\begin{array}{l}\text { High financial income for the organization and implementation of illegal } \\
\text { transportation of persons across the state border of Ukraine to the countries } \\
\text { of the Schengen agreement }\end{array}$ \\
\hline 1.6 & $\begin{array}{l}\text { High unemployment rate in border areas, close family ties between residents } \\
\text { of the border area of Ukraine and neighboring countries }\end{array}$ \\
\hline 1.7 & $\begin{array}{l}\text { Difficult terrain in places where the state border passes, the presence } \\
\text { of mountainous, wooded areas, which limits the use of optoelectronic devices } \\
\text { in border protection and allows illegal migrants, illegal activity guides } \\
\text { to approach the state border covertly }\end{array}$ \\
\hline 1.8 & $\begin{array}{l}\text { Absence of criminal liability, significant fines for illegal crossing of the state } \\
\text { border, for smuggling, for violation of migration legislation and loyal attitude } \\
\text { of the courts in the direction of punishment for crimes under article } 332 \\
\text { of the criminal code of Ukraine }\end{array}$ \\
\hline 1.9 & Lack of an effective mechanism for deporting illegal migrants \\
\hline 1.10 & Low staffing of border protection units (50-60\%) \\
\hline 1.11 & $\begin{array}{l}\text { Rotation of the management of units, which does not allow to deal with the } \\
\text { situation and respond adequately to its changes, does not allow to effectively } \\
\text { manage the division }\end{array}$ \\
\hline 1.12 & $\begin{array}{l}\text { Corruption, involving or facilitating illegal activity on the state border } \\
\text { of the state security service of Ukraine }\end{array}$ \\
\hline 1.13 & $\begin{array}{l}\text { Corruption in migration and law enforcement agencies, which makes it impossible } \\
\text { to prevent illegal migrants and contraband goods from entering the border zone }\end{array}$ \\
\hline 1.14 & $\begin{array}{l}\text { Activity of national diasporas and communities on the territory of Ukraine } \\
\text { (Afghanistan, Pakistan, Somalia, Georgia, Armenia, etc.) that provide conditions } \\
\text { for illegal migration }\end{array}$ \\
\hline 1.15 & $\begin{array}{l}\text { Activity of transnational and cross-border criminal groups that specialize in } \\
\text { smuggling illegal migrants, human trafficking and smuggling of narcotic and } \\
\text { psychotropic substances, a stable and extensive support base among residents of the } \\
\text { border area }\end{array}$ \\
\hline 1.16 & $\begin{array}{l}\text { Continued improvement of border and immigration policies by EU governments, } \\
\text { strengthening of the EU external border protection system by border agencies of } \\
\text { neighboring countries, and increasing efforts to develop border infrastructure and } \\
\text { technical equipment for units }\end{array}$ \\
\hline 1.17 & $\begin{array}{l}\text { Lack of proper technical equipment of border units (vehicles, thermal imaging } \\
\text { systems and devices, radar for detecting MLA UAVs), insufficient engineering } \\
\text { arrangement of the border, especially along the Tisa river }\end{array}$ \\
\hline 1.18 & $\begin{array}{l}\text { Limitations of material and financial resources to perform the tasks } \\
\text { in securing the border }\end{array}$ \\
\hline 1.19 & $\begin{array}{l}\text { Insufficient equipment of certain parts of the boundary ( «Tisa», «Salovka», } \\
\text { «Palad - Komarivtsi») }\end{array}$ \\
\hline 1.20 & $\begin{array}{l}\text { Use by offenders of the latest thermal imaging, optical devices, and modern } \\
\text { unmanned aerial vehicles (drones) in order to expose the border security system }\end{array}$ \\
\hline 1.21 & $\begin{array}{l}\text { The use of aircraft for the illegal movement of goods and persons across the state } \\
\text { border (with the help of aircraft, offenders carry out the movement of illegal } \\
\text { migrants, cigarettes from the rear areas located outside the border controlled areas) }\end{array}$ \\
\hline \multicolumn{2}{|r|}{ II. Minor threat vulnerabilities } \\
\hline 2.1 & $\begin{array}{l}\text { Unstable socio-economic and political situation in Ukraine and its destabilization } \\
\text { by pro-Russian forces }\end{array}$ \\
\hline 2.2 & $\begin{array}{l}\text { Significant difference in prices for tobacco products in Ukraine and neighboring } \\
\text { countries }\end{array}$ \\
\hline
\end{tabular}




\begin{tabular}{|l|l|}
\hline \multicolumn{1}{|c|}{ № } & \multicolumn{1}{c|}{ Vulnerabilities } \\
\hline 2.3 & $\begin{array}{l}\text { High unemployment rate in border areas, close family ties between residents } \\
\text { of the border area of Ukraine and neighboring countries }\end{array}$ \\
\hline 2.4 & $\begin{array}{l}\text { Corruption, involving or facilitating illegal activity on the state border of the state } \\
\text { security service of Ukraine }\end{array}$ \\
\hline 2.5 & $\begin{array}{l}\text { No criminal liability, significant fines for smuggling, or violation } \\
\text { of customs legislation }\end{array}$ \\
\hline 2.6 & $\begin{array}{l}\text { The lack of proper technical equipping of border crossing points } \\
\text { (common database, inspection scanners) }\end{array}$ \\
\hline 2.7 & $\begin{array}{l}\text { Low staffing of border protection units, which causes a significant service load } \\
\text { on the staff, and as a result - a decrease in the efficiency of the service }\end{array}$ \\
\hline 2.8 & $\begin{array}{l}\text { Discrepancy in the capacity of checkpoints, which significantly reduces the } \\
\text { efficiency of passport and inspection work }\end{array}$ \\
\hline
\end{tabular}

The points listed in the table can be attributed to the sphere of influence: 1.1-1.4, 1.5, 1.6, 1.16, 2.1-2.3 and 2.8 - socio-political; 1.9, 1.13-1.15, 2.4, 2.5 law enforcement agencies (SSU, MIA, OPGU, etc.); 1.10-1.12, 2.6, 2.7 the managerial staff of the State Border Guard Service (their resolution requires some research); 1.7 - operational and tactical level of management of border units, elimination of this vulnerability depends on making adequate management decision to find scientifically sound ways and mechanisms of organization of counteraction to the mentioned criminal activity.

The ways of trafficking people across the state border are constantly changing under the influence of migration and other factors ${ }^{23}$.

In view of this, it is imperative to investigate ways of committing crimes that reveal the peculiarities of the activities of the diverse body of actors involved in its commission, which is inherent in organized criminal activity related to the illegal movement of illegal migrants across the state border.

Taking into account the peculiarities of criminal activity, which is connected with the illegal trafficking of persons across the state border, in our opinion, the way of transfer of persons across the state border is defined as an interdependent set of actions of persons whose activity is generally aimed at transferring persons across the state border of Ukraine violating the current legislation requirements, as well as persons who cross the state border of Ukraine ${ }^{24}$.

${ }^{23}$ Kapitanchuk L. Yu. (2009) Okremi pytannja rozsliduvannja porushenj derzhavnogho kordonu Ukrajiny za uchastju neleghaljnykh mighrantiv [Separate issues of investigation of violations of the state border of Ukraine with the participation of illegal migrants]. Universytetsjki naukovi zapysky, no. 1. pp. 306-312. (in Ukrainian)

${ }^{24}$ Kapitanchuk L. Yu. (2008) Sposib vchynennja zlochynu ta jogho osoblyvosti pry nezakonnomu perepravlenni osib cherez derzhavnyj kordon Ukrajiny [Sposib vchynennja zlochynu ta jogho osoblyvosti pry nezakonnomu perepravlenni osib cherez derzhavnyj kordon Ukrajiny]. Forum prava, no. 2, pp. 210-219. (in Ukrainian) 
The analysis of criminal activities related to the illicit movement of persons, including illegal migrants across the state border, shows that traffickers are constantly taking steps to improve existing methods and develop new ones in order to minimize the effectiveness of law enforcement.

The practice of combating illegal migration shows that irregular migrants travel to EU countries across the national border outside the border crossing points (from 3 to 8 people), both individually (using maps and GPS navigators), and accompanied by local border assistants or representatives of foreign diasporas.

Legalization of illegal migrants on the territory of Ukraine is carried out by: first, changes in the status of stay (receiving MIA records on employment, temporary residence or study), second, the extension of your stay, third, the use of the refugee status procedure ${ }^{25}$.

The analysis of the results of the operational service of the border unit in the period from June 2017 to May 2018 in comparison with the same previous period shows a slight decrease in the activity of illegal crossing of the state border by illegal migrants. The most active is the Slovak border area, where $91 \%$ of attempts to violate the state border and $9 \%$ at the border with Hungary and $1 \%$ at the border with Poland were stopped during the study period.

Analyzing the general trends of 2016-2018, we can notice the dynamics of illegal activity by periods of the year, which shows that the decline in activity is observed in January - March, which is primarily due to seasonal deterioration of weather conditions and $100 \%$ readmission of detained illegal migrants since November 2016.The peak periods in this type of illegal activity in the area of responsibility of the border detachment were: in 20162017 - May, August, in 2017-2018 - May, August - September.

The most active time of day was the time from $8 \mathrm{pm}$ to $8 \mathrm{am}$. The highest activity of attempts of illegal crossing on the state border by illegal migrants took place within the areas of responsibility of Uzhgorod BGD, Huta BGIS, Palad Komarivtsi BGIS, Novoselytsya and Stuzytsya BGIS.

The main way of getting migrant groups to Ukraine is on the border with the Russian Federation outside the border crossing points. Due to the warfare in the east of Ukraine, illegal elements began to make more active use of border areas within the north-eastern regions of Ukraine (Kharkiv, Sumy,

${ }^{25}$ Kapitanchuk L. Yu., Litvin Yu. I. (2015) Vplyv zminy potokiv neleghaljnoji mighraciji na formuvannja kryminalistychnoji kharakterystyky nezakonnogho perepravlennja osib cherez derzhavnyj kordon Ukrajiny [Influence of Changes in Illegal Migration Flows on Formation of Forensic Characteristics of Illegal Trafficking of Persons across the State Border of Ukraine]. Dosudove rozsliduvannja : aktualjni problemy ta shljakhy jikh vyrishennja : materialy postijno dijuchogho nauk. - prakt. seminaru. Pravo, no. 7. pp. 344. (in Ukrainian) 
and Chernihiv regions). As a rule, the transportation of illegal migrants was carried out from Moscow to the places of accumulation and formation of groups on the territory of Ukraine (Kyiv, Odessa) and further to the Transcarpathian region. In this case, as a rule, automobile transport means (cars, minibuses) were used for delivery to the border, and automobile transport means of improved cross-country performance for direct delivery to the state border.

A relatively new element of the tactics of illegal elements was the «temporary legalization» of foreigners on the territory of Ukraine upon their arrival through the established crossing points (mainly - the airports «Boryspil», «Zhuliany», «Odessa» [Dubai-Kiev connecting flights, «Istanbul - Odessa» and «Istanbul - Kiev»). In particular, short-term visas are issued to foreigners through representatives of travel companies at the airport, which give legal grounds for staying in Ukraine for a short time. Furthermore, illegal migrants are deprived of their documents and illegally trafficked by organizers of illegal activities on the western border.

The use of settlements in Perechyn, Chop, Velyka Berezny and Uzhgorod districts for the short-term detention of migrant groups before their direct cross-border transferring is the characteristic feature of the tactics of the criminal groups. The tasks of transportation, hiding of groups on the border and escorting them across the border were carried out by both persons from criminogenic environment and by single persons involved.

Transportation of groups of illegal migrants to the Transcarpathian region is carried out mainly from Kharkiv, Lviv, Kyiv and Odessa. Delivery of unorganized groups of illegal migrants by buses is carried out mainly by inter-oblast buses «Kyiv - Uzhgorod», «Lviv - Uzhgorod», «IvanoFrankivsk - Uzhgorod», «Chernivtsi - Uzhgorod», «Rakhiv - Uzhgorod».

Delivery of small groups of illegal migrants by railway can be carried out by trains by connection No 81 «Kyiv-Uzhgorod», No. 13 «Kyiv-Uzhgorod», No. 99 «Kyiv-Uzhgorod», No. 107 «Odessa-Uzhgorod», No. 601 «Lviv Solotvyno» and No. 829 "Lviv-Uzhgorod".

Regarding the tactics of unorganized groups of illegal migrants and small groups that are transported with the help of assistants, it is worth noting that, upon arrival in the Transcarpathian region, illegal migrants are settled in private apartments (houses). After some time, they are usually escorted by two or three people (guides) across the state border by car or on foot. As a rule, organizers of the illegal transfer of persons involve 1 well-oriented local resident and 1-2 conductors from the settlements far from the border area. Small groups of illegal migrants (in most cases up to 5 people) are escorted to the border barrier or to the state border line.

Later on, migrants independently move to the nearest settlement on the adjacent territory. Traffic routes to the border are chosen in such a way as to 
minimize the occurrence of locals on the route, as well as to provide maximum concealing with the help of terrain features. As a rule, observers move forward in a small distance in front of a group of migrants to monitor the possible appearance of border guard patrol units.

In the case of detention in an adjacent territory, migrants use the socalled "treatment of the refugee status" tactics in order to avoid readmission in the territory of Ukraine. During the preparation of the procedural documents by the representatives of the law enforcement agencies, the migrants indicate deliberately false constituent data, use the "legends" that have been brought to them (emphasis is placed on the fact that they are minors, constantly repudiation of actual staying in Ukraine, etc.).

In total, at the detachment sector 417 irregular migrants were detained during June, 2017 and May, 2018, in 90 cases. [1] (a decrease of 1.7 times by the number of detained persons [248 persons were detained during the same period in 93 cases]).

Including the SBGS units: in 47 cases, $52 \%$ of the total cases in the period from 06.2017 to $05.2018,161$ irregular migrants, $39 \%$ of the total number of detainees (an increase of $5 \%$ on cases and $25 \%$ on the number detainees [during the same period in the past, in 45 cases detained 120 persons]); Border Guard Units of Adjacent Country: during 06.2016 and 05.2017 , in 43 cases, $48 \%$ of the total number of cases, 258 irregular migrants, $61 \%$ of the total number of detainees $(5 \%$ reduction in cases and 2 times the number of detainees [during the same period in the past, in 48 cases detained 128 persons]).

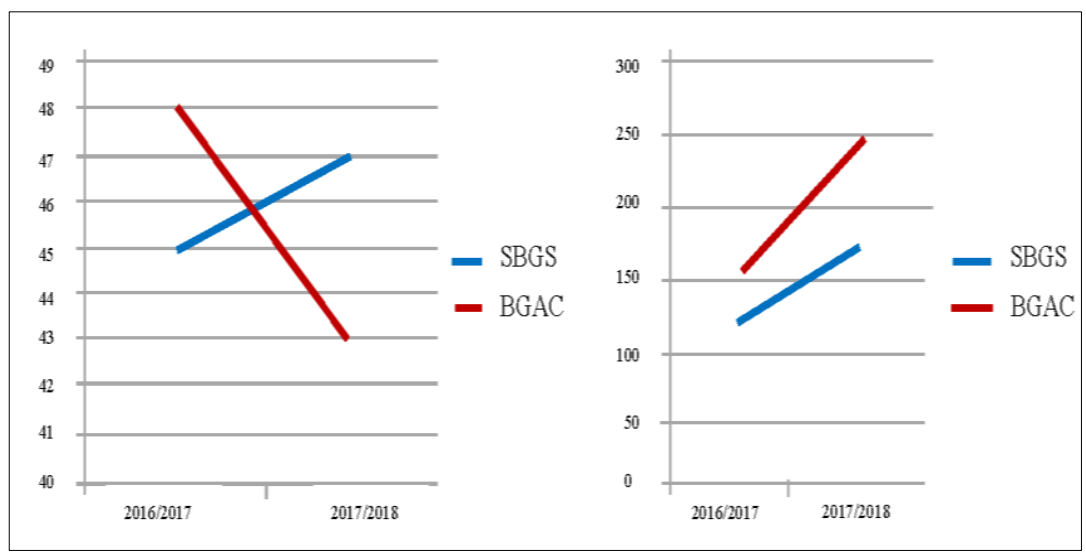

Fig. 1. Dynamics of detention of irregular migrants 
During this period, 417 people were detained in 90 cases, including:

Ukrainian and Slovakian border sector: in 77 cases, $85 \%$ of the total number during the report period, 365 irregular migrants, $87 \%$ of the total detainees during the reported period.

Ukrainian and Hungarian border sector: in 7 cases, $8 \%$ of the total number 24 irregular migrants during the report period, $6 \%$ of the total detainees during the reported period;

Ukrainian and Polish border sector: in 6 cases, 7\% of the total number 28 irregular migrants during the report period, $7 \%$ of the total number of detainees during the reported period;

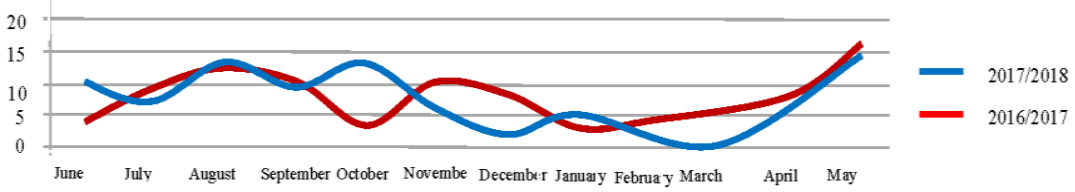

Fig. 2. Cases

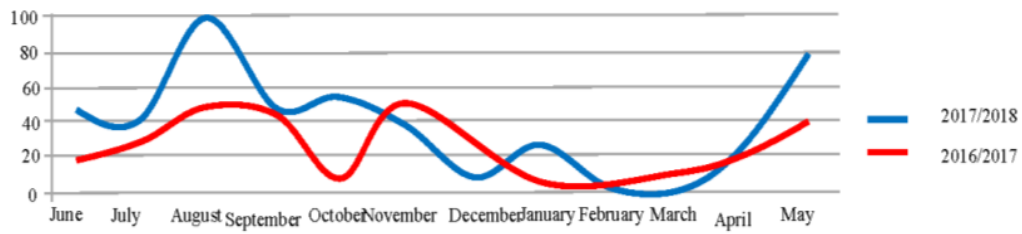

Fig. 3. Detained persons

The analysis of the results of the operational and service activity of the units of the state border protection indicates that the stable threat of illegal activity production with the use of new tactics and the latest technical means, and the OSA processes outside the checkpoints have a previously unpredictable (accidental) nature.

In 2018 - 2019, the border detail revealed «photo traps» that were disguised installed along the route of the border patrols. When border details appered in the range of the device in real time, the photo from the device was sent to a pre-programmed mobile phone number of the irregular element. In this way, the situation was monitored by illegal elements and the system of state border guard protection was opened. 
Illegal elements have been actively used by unmanned aerial vehicles (UAVs) to track the movement of border details, as well as to smuggle small batches of cigarettes.

For small aerial vehicle (SAV) tactics, landing strips were used at various locations outside the boundary strip in the rear areas of the controlled border guard region, border guard area or other areas of the country. On the adjacent territory the cargo (up to 10 packs of cigarettes) is dumped into the designated place without landing the aerial vehicle with the subsequent return to the territory of Ukraine. As a rule, flights are made at night in order to complicate the possibility of visual observation and a low altitude to avoid their detection by technical means of aerial defense of the Ministry of Defense of Ukraine. Delivery of SAV was carried out disassembled in cargo minibuses. Subsequently, they were quickly assembled, loaded with tobacco goods. The flights were made at night by GPS navigators by professional pilots. On the adjacent territory SAVs could not land, throwing cigarettes on the go.

Returning were made in a different direction to a predefined platform. When SAV lands, it knocked down and loaded in vehicles. The tactics of the action are characterized by greater mobility of the use of technical means, such as night vision equipment, GPS navigators, mobile phones, etc.

In March 2018, using the AN-2 aircraft, the illegal movement of a group of 11 irregular migrants from the backland of Ukraine to Hungary was made, so the possibility of using SAVs for the illegal movement of irregular migrants across the state border is not excluded.

During June 2016 - May 2018, 40 airspace violations were reported, 3 SAVs were detained.

During June 2017 - May 2018, 23 airspace violations were reported. 3 UAVs were detained.

Based on the analysis of SVA violations and UAVs during 2016-2018, it can be stated that the most active areas of possible engagement of SVAs are: Salovka, Tisa, Palad Komarivtsi BG Divisions. Period from March to October should be considered like a minatory period.

The most active areas of possible engagement of UAVs are: Tysa BG Division, Salovka BGIS, Palas Komarivtsi bgis, Uzhhorod BGD. A minatory period is favorable weather conditions during the year.

Since November 2016 due to the $100 \%$ readmission of detained irregular migrants by EU countries, the activity of irregular migrants has significantly decreased since the end of Q1 2017. If such a migration policy is continued in 2020, less active channels of irregular migration should be expected, which will be discredited by themselves. At the same time, there will be unorganized attempts at illegal border crossings or organized attempts to move of small groups of 3-8 irregular migrants.

The policy of the EU, Turkey and the Russian Federation in relation to refugees will influence on the flow of migrants, the tactics of OSGs' actions 
to move irregular migrants. In case of a certain overlap of irregular migrants channels in the South of EU, it is possible to make refocusing of the channels through the territory of Russia and Ukraine with the subsequent entry of some irregular immigrants from Russia to Ukraine via the CIS ERD section or transit through the Republic of Belarus (northern stream), transit by sea (southern stream). The reason will also not be the completion of the project 'Wall' on the Ukrainian and Russian borders with a total length of $1300 \mathrm{~km}$, the completion of which is possible by the end of 2020, but the deadlines are not concrete.

This stream of irregular migrants entered to the EU using the status of refugee, may be citizens of the Russian Federation. Also, these citizens can be involved to IAGs in Donetsk and Luhansk regions.

Accordingly, the probability of activity of illegal migration to Ukraine with the further penetration in the EU countries will be relevant.

at the Ukrainian and Polish section may be attempts to smuggle irregular migrants at the junction of the Verkhovyna Bystra and the Velykyi Bereznyi BG Divisions of the Border Guard Service;

use of the bgd sectors for the transit movement of irregular migrants originating from Africa, South east Asia to the Ukrainian and Slovakian border section;

violation of the state border regime by the citizens of Ukraine and Poland during the tourist season and the season of collecting wild berries.

in the Ukrainian and Slovakian section is the continuation of attempts by organized illegal groups to cross irregular migrants across the border to the Slovak Republic, mainly from Vietnam, Afghanistan, India, Bangladesh and Syria in the Velykyi Bereznyi region.

According to the reduced analysis, it is proposed to carry out the following measures to minimize threats and risks in the area of the Chop Border Guard Detachment:

1. Organization of detailed interaction with law enforcement agencies, OSD units on specific threats. Exchange of information on the tactics of the offenders, the number of persons, vehicles involved to a specific type of illegal activity. Elaboration of joint interaction plans and administrative documents with a distinction between powers and procedures.

2. Improving the exchange of information with a adjacent Country about a possible offense (not only criminal) both at checkpoints and outside them, with the possibility of providing supporting documents, photo and video materials. Conducting joint investigations, especially with regard to the accomplices of the offense.

3. Carrying out comprehensive measures in cooperation with other law enforcement agencies on combating corruption and involving staff in unlawful activities. Provide a systematic approach is motivating the staff for positive results of service, including the local border guard population. 
4. Permanent collection of pre-emptive information about a possible offense at a border or at a checkpoint,

5. Updating of databases, risk profiles and prompt bringing of changes in the situation to the border patrols and reserves.

6. Strengthen work on the selection of candidates for military service under contract.

7. Creating the right conditions to serve at the state border: limiting staff rotations, optimizing workloads, maintaining unit communications in workforce, utilizing specialty staff, improving nutrition, provisioning according to climatic conditions, etc.

8. Extension of the engineering and technical component of border guard protection, firstly the arrangement (restoration) of a fence, purchase of thermal and signaling equipment of a new sample.

\section{CONCLUSIONS}

During the analysis it was found that irregular migration is the crossing of state borders for the purpose or in a manner that violates its legislation, including international ones. All OSG processes outside the checkpoints have a previously unpredictable (random) nature. The parameters of the conditions in the area of responsibility of the Chop Border Detachment have both deterministic and uncertain character. Therefore, the effectiveness assessment model and partial performance indicators of counteracting irregular migration should be probabilistic. The methodology should solve the scientific problem of the rational distribution of forces and means of the Chop Border Detachment, taking into account the conditions of performance of tasks in specific territories of the entire area of responsibility.

\section{SUMMARY}

For the purpose of qualitative fulfillment of tasks, which are legally prescribed to the State Border Guard Service of Ukraine, the border units, within their competence, should adequately respond to the threats that appear in the area of border activity. The scientific article deals with the specifics of service operational activities implementation at the sector of Chop Border Detachment responsibility. The statistics analysis on illegal migration counteracting at green border was conducted and the specific tactics of border violators' actions were revealed. The conclusion on the necessity of finding ways to improve the efficiency of illegal migration counteracting organization at green border and the limited capacity of the available scientific and methodological apparatus for the rational distribution of border units' means and forces, taking into account the specific sector of Chop Border Detachment responsibility is presented in the article.

The author concludes that the parameters of the situation conditions at the sector of Chop Border Detachment responsibility are both deterministic 
and undefined. Therefore, the efficiency evaluation model and partial efficiency indicators should be probabilistic.

\section{REFERENCES}

1. Tematychnyy analiz ryzykiv: vyznachennya zahroz ta ryzykiv na dilyantsi zahonu $\mathrm{z}$ metoyu vyznachennya zavdan' pidporyadkovanym pidrozdilam na okhoronu derzhavnoho kordonu v 2019 rotsi (2018) [Thematic Risk Analysis: Identifying Threats and Risks at the Detachment Area to Identify Tasks for Subordinate Border Protection Units in 2019]. Chop, p. 26. (in Ukraine)

2. Stratehiya intehrovanoho upravlinnya kordonamy na period do 2025 roku [Elektronuj resurs] Rozporyadzhennya Kabinetu Ministriv Ukrayinu vid 24 lypnya 2019 roku № 687-r. Rezhum dostupu: https://zakon.rada.gov.ua/laws/show/687-2019-\%D1\%80 (data zvernennya: 30.12.2019) [An integrated border management strategy for the period up to 2025: [Electronic Resource] Order of the Cabinet of Ministers of Ukraine No. 687-r as of July 24, 2019, available at: https://zakon.rada.gov.ua/ laws/show/687-2019-\%D1\%80].

3. Pro Rishennya Rady natsionalnoyi bezpeky i oborony vid 06 travnya 2015 r. «Pro Stratehiyu natsionalnoyi bezpeky Ukrayiny». Ukaz Prezydenta Ukrayiny vid 06 travnya 2015 r. №287/2015. [Elektronuy resurs] - Rezhy`m dostupu: http://zakon3.rada.gov.ua/laws/show/n0008525-15 [On the Decision of the National Security and Defense Council as of May 06, 2015 « About the National Security Strategy of Ukraine» Decree of the President of Ukraine as of May 06, 2015, available at: http://zakon3.rada.gov.ua/laws/ show/n0008525-15.

4. Zakon Ukrayiny № 661-IV «Pro derzhavnu prukordonnu sluzhbu Ukrayinu» vid 3 kvitnya 2003 roku (Vidomosti Verxovnoyi Radu Ukrayinu, 2003, N 27, st. 2, 20). [Law No. 661-IV of Ukraine On the State Border Service of Ukraine as of April 3, 2003 (The Official Bulletin of the Verkhovna Rada of Ukraine (OBVR)), 2003, 27, Art. 208)]. [in Ukrainian]

5. Mejko O. V. (2014) Metoduka vuznachennya racionalnogo varianta zastosuvannya mobilnux grup okremogo viddilu prukordonnoyi sluzhbu tupy "S" pid chas uskladnennya obstanovku na dilyankax derzhavnogo kordonu [Methods of determining the rational variant of the use of Type C mobile teams of a separate department of the border service during the aggravation of the situation at the state border sections] Zbirnyk naukovykh prats, Kharkiv : KNAFU, No. 4 (41), pp. 153-156. [in Ukrainian]

6. Farion O. B. (2009) Metoduka ocinku efektuvnosti sustemu informacijnogo zabezpechennya viddilu prukordonnoyi sluzhbu tupy «B» [Methods of evaluation of the effectiveness of the system of information support of the Type B department of the border service] Zbirnyk naukovykh prats Natsionalnoi akademii Derzhavnoi prykordonnoi sluzhby Ukrainy im. 
B. Khmelnytskoho, Khmelnytskyi : NASBSU, no. 49, pp. 97-115. [in Ukrainian]

7. Kovalev D. V. (2017) Algorutm metoduku vuznachennya racionalnogo varianta organizaciyi operatuvno-sluzhbovoyi diyalnosti viddiliv prukordonnoyi sluzhbu tupy "A" $\mathrm{v}$ kontrolnux punktax vyizdu/vyjizdu [Algorithm of methodology of determination of rational variant of organization of operatively-official activity of departments of frontier service as "A» in the markpoints of entrance/of departure]. Zbirnyk naukovykh prats Natsionalnoi akademii Derzhavnoi prykordonnoi sluzhby Ukrainy im. B. Khmelnytskoho, Khmelnytskyi : NASBSU, no. 2(72), pp. 116-125. [in Ukrainian]

8. Shinkaruk O. M., Mosov S. P., Kirilenko V. A. (2018) Prykordonna bezpeka Ukrayiny: stanovlennya, suchasnyy stan, problemy i perspektyvy: monohrafiya [Border security of Ukraine: formation, current state, problems and prospects: monograph]. Khmelnytsky : NASBSU, p. 187 p. [in Ukrainian]

9. Blazhivsky E. M. (2008) International migration is one of the biggest problems of modern Ukraine. Visn. prokuratu, no. 6. pp. 3-13. [in English]

10. Rashitov L. R. (2016) Criminological characteristics of crimes in the sphere of illegal migration and their prevention. BULLETIN of the Kazan law Institute of the Ministry of internal Affairs of Russia, no. 1(23), pp. 124-28. (in English)

11. Malinovska O. A. (2018) Migration policy: global context and Ukrainian realities: monograph. Kiev : NISD, 472 p. (in English)

12. Purygina O. G. (2007) International migration: studies. stipend. Kiev : VC «Academy», 312 p. (in English)

13. Babiia V. M., Koretsky V. M. (1974) Law dictionary / edited by academics of VSSR Academy of Sciences. Kiev, 844 p. (in English)

14. Gusarov S. M., Komzuk A. T., Salmanova A. Yu. (2016) Migration law of Ukraine : textbook. Kharkiv : advertising House, 296 p. (in English)

15. Kuzmenko O. V. (2000) Administrative and legal counteraction to illegal migration in Ukraine: dis. ... Cand. Law. Sciences. Kiev, 196 p. (in Ukrainian)

16. Mosiondz S. O. (2005) Administrative and legal bases of the state migration policy in Ukraine. Kiev : Master of the twenty-first century, $206 \mathrm{p}$. (in Ukrainian)

17. On the legal status of foreigners and stateless persons. Law of Ukraine No. 3773-VI of September 22, 2011 (Vidomosti Verkhovnoi Rady Ukrainy (VVR), 2012, No. 19-20, art. 179) . Retrieved from: https://zakon.rada.gov.ua/laws/show/3773-17. (in Ukrainian)

18. Binkovskyi O. A., Zalozh V. V., Dovgan V. I. (2016) Mechanisms for countering irregular migration in Ukraine. Eurasian Academic Research Journal, no. 2(02), pp. 14-22. (in English)

19. Shevchenko O. M. (2010) Udoskonalennja mekhanizmiv derzhavnogho upravlinnja mighracijnymy procesamy [Improving the 
mechanisms of state management of migration processes]. Donetsk. 2010. 25 p. (in Ukrainian)

20. Zakharchenko M. (2014) Prychyny ta sutnistj javyshha nereghuljarnoji (neleghaljnoji) mighraciji [Reasons and essence of the phenomenon of irregular (illegal) migration]. Customs activity, pp. 262-267. (in Ukrainian)

21. Mozol A. P. (2002) Kryminologhichni problemy neleghaljnoji mighraciji $\mathrm{v}$ Ukrajini [Criminological problems of illegal migration in Ukraine]. Kiev, 212 p. (in Ukrainian)

22. Ognev T. E. (2017) Nereghuljarna mighracija: kryminaljne pravo ta kryminologhichni aspekty [Irregular migration: criminal law and criminological aspects]. Institute of state and law. V. M. Koretsky, 20 p. (in Ukrainian)

23. Kapitanchuk L. Yu. (2009) Okremi pytannja rozsliduvannja porushenj derzhavnogho kordonu Ukrajiny za uchastju neleghaljnykh mighrantiv [Separate issues of investigation of violations of the state border of Ukraine with the participation of illegal migrants]. Universytetsjki naukovi zapysky, no. 1. pp. 306-312. (in Ukrainian)

24. Kapitanchuk L. Yu. (2008) Sposib vchynennja zlochynu ta jogho osoblyvosti pry nezakonnomu perepravlenni osib cherez derzhavnyj kordon Ukrajiny [Sposib vchynennja zlochynu ta jogho osoblyvosti pry nezakonnomu perepravlenni osib cherez derzhavnyj kordon Ukrajiny]. Forum prava, no. 2, pp. 210-219. (in Ukrainian)

25. Kapitanchuk L. Yu., Litvin Yu. I. (2015) Vplyv zminy potokiv neleghaljnoji mighraciji na formuvannja kryminalistychnoji kharakterystyky nezakonnogho perepravlennja osib cherez derzhavnyj kordon Ukrajiny [Influence of Changes in Illegal Migration Flows on Formation of Forensic Characteristics of Illegal Trafficking of Persons across the State Border of Ukraine]. Dosudove rozsliduvannja : aktualjni problemy ta shljakhy jikh vyrishennja : materialy postijno dijuchogho nauk. - prakt. seminaru. Pravo, no. 7. pp. 344. (in Ukrainian)

\section{Information about the author: Volodymyr Kyrylenko,}

Doctor of Technical Sciences, professor, chief research fellow,

Bohdan Khmelnytskyi National Academy of the State Border Guard Service of Ukraine 46 Shevchenka str., Khmelnitskyi, 29007, Ukraine

ORCID ID: orcid.org/0000-0002-2206-1651 


\section{THE METHOD OF COORDINATED TRAINING FOR JOINT ACTIONS OF FORCES OF SECURITY AND DEFENSE SECTOR OF UKRAINE OF DIFFERENT AFFILIATIONS IN THE CONTEXT OF AN INTERNATIONAL COOPERATION (ON THE EXAMPLE OF BORDER SECURITY GUARANTEEING ENTITIES)}

\section{Dmytro Kupriyenko}

\section{INTRODUCTION}

Despite the complexity of the military-political and socio-economic situation, the border policy of Ukraine is aimed at maximum consolidation of the potential of the entities of the security and defense sector of the state (law enforcement agencies and military units) in order to guaranteeing national security ${ }^{1}$. In particular, built in 2010, Integrated Border Management (hereinafter - IBM) system moved in 2019 to a new stage of development by increasing the number of entities of this system, and also optimizing their entities in the vector of ensuring an adequate border security level that, in particular, is one of the criteria of realization of Eurointegration course of Ukraine ${ }^{2,3}$.

So, in particular, in the National Security Strategy of Ukraine ${ }^{4}$ in the provision on the creation of an effective security and defense sector, it is

${ }^{1}$ Shynkaruk O. M., Lysyi M. I., Kupriyenko D. A. (2019) Suchasnyi stan prykordonnoho bezpekovoho seredovyshcha Ukrainy [The modern state of the border security environment of Ukraine]. Scientific Works of Kharkiv National Air Force University, Vol. 3(61), pp. 135-145. https://doi.org/10.30748/zhups.2019.61.17. (in Ukrainian)

${ }^{2}$ Rozporiadzhennia Kabinetu Ministriv Ukrainy vid 24 lypnia 2019 r. № 687-r (2019) Pro skhvalennia Stratehii intehrovanoho upravlinnia kordonamy na period do 2025 roku [On the approval of the Integrated Border Management Strategy for the period up to 2025]. Retrieved from: https://zakon.rada.gov.ua/laws/show/687-2019-\%D1\%80 (accessed 12 Jan. 2020). (in Ukrainian)

${ }^{3}$ Mizhnarodnyi dokument vid 27.06.2014 (2014) Uhoda pro asotsiatsiiu mizh Ukrainoiu, z odnoho boku, ta Yevropeiskym Soiuzom, Yevropeiskym spivtovarystvom z atomnoi enerhii i yikhnimy derzhavamy-chlenamy, $\mathrm{z}$ druhoho boku [Association Agreement between Ukraine, of the one part, and the European Union, the European Atomic Energy Community and their Member States, of the other part]. Retrieved from: https://zakon.rada.gov.ua/go/984_011 (accessed 12 Jan. 2020). (in Ukrainian)

${ }^{4}$ Ukaz Prezydenta Ukrainy vid 26.05.2015 № 287/2015 (2015) Pro rishennia Rady natsionalnoi bezpeky i oborony Ukrainy vid 6 travnia 2015 roku „Pro Stratehiiu natsionalnoi bezpeky Ukrainy" [On the decision of the National Security and Defense Council of Ukraine of May 6, 2015 "On the National Security Strategy of Ukraine"]. Retrieved from: https://zakon.rada.gov.ua/go/287/2015 (accessed 12 Jan. 2020). (in Ukrainian) 
stated that the formation and development of the security and defense sector, which should provide an adequate and flexible response to threats, rationally using opportunities and resources, is a priority of national security policy. At the same time, it is necessary to ensure: the introduction of an integrated system of education, combat and special training of personnel of the security and defense sector with the involvement of teachers, instructors from NATO Member States, the European Union (EU), the formation of a new security culture.

Item, nowadays, intensive processes of political, socio-economic, defense and security synchronization and harmonization are obviously taking place in the European region. Therefore, the issues of building a "space of freedom, security and justice/due process of law", as well as a deep and comprehensive free trade area, remain relevant on the agenda. The center of gravity of this problem is gradually shifting from the internal to the external dimension of the EU, which opens up more opportunities for cooperation with countries that have common borders (Eastern Partnership countries) $)^{5,6}$.

Within the framework of this policy, one of the main vectors of the activities of the European Union is the construction / modernization / improvement of the border security guaranteeing (hereinafter - BSG) system, which would guarantee open, but at the same time controlled and safe external borders between the states. However, these requirements for the BSG system are quite contradictory. On the one hand, it should effectively counteract real and potential threats at a certain level (local, national, regional and international (global)), and on the other hand, it should fully comply with the standards/requirements/norms of legitimate crossborder activities and respect for fundamental human rights.

To this end, the European Commission has developed and in 2002 implemented a border policy, which was officially called "Integrated Border Management"7. At the same time, it should be emphasized that there are other concepts indicating the need for a more complete interaction of all

\footnotetext{
${ }^{5}$ Bodruk O. S. (2001) Struktury voiennoi bezpeky: natsionalnyi ta mizhnarodnyi aspekty : monohrafiia [Military security structures: national and international aspects: monograph]. Kyiv : $N I P M B, 300$ p. (in Ukrainian)

${ }^{6}$ Brezhnieva T., Yizhak O., Shevtsov A. (2003) Yevroatlantychna intehratsiia Ukrainy: viiskovo-politychni aspekty : monohrafiia [Ukraine's Euro-Atlantic integration: militarypolitical aspects: monograph]. Dnipropetrovsk : Porohy, 160 p. ISBN: 966-525-424-3. (in Ukrainian)

7 Communication to the Council and the European Parliament. Towards integrated management of the external borders of the member states of the European Union. Brussels, 7 May 2002, $\operatorname{COM(2002)~} 0233$ final, 28 p. Retrieved from: https://eur-lex.europa.eu/legalcontent/EN/TXT/?uri=celex:52002DC0233 (accessed 12 Jan. 2020). (in Ukrainian)
} 
actors whose activities are in one way or another related to border and crossborder activities, for example, it can be integrated, coordinated, coherent, joint border management, but it does not significantly affect the practice of border policy ${ }^{8,9,10}$.

It is important to note that the development and adoption of national concepts (strategies) BSG is one of the mandatory criteria for readiness for European integration (in the systems of Copenhagen and Madrid criteria $^{11,12}$. For example, the BSG mechanism was implemented to varying degrees in the public administration system of the Member States of the European Union ${ }^{13}$, the Eastern Partnership countries (Armenia, Azerbaijan, Belarus, Georgia, Moldova, Ukraine), countries of Africa and Central Asia. In particular, for Ukraine, the first stage of the action Plan on visa liberalization ${ }^{14}$ was provided:

approval of the National Strategy for IBM and an Action Plan for its effective implementation, which defines a time frame and specific goals for the development of legislation, organization, infrastructure, facilities, as well

\footnotetext{
${ }^{8}$ EuropeAid (2010) Cooperation Office Guidelines for Integrated Border Management in European Commission External Cooperation. Brussels, 152 p. Retrieved from: https://europa.eu/capacity4dev/file/21153/download?token=31OSGDjf (accessed 12 Jan. 2020). (in Ukrainian)

${ }^{9}$ McLinden G., Fanta E., Widdowson D. and Doyle Th. (2010) Border Management Modernization: A Practical Guide for Reformers : conference edition. Washington, D.C.: The World Bank. Retrieved from: https://pdfs.semanticscholar.org/6043/4817c84ea9a4d74187 4fc98301b8bc2bb843.pdf (in Ukrainian)

${ }^{10}$ Doyle T. (2010) Collaborative border management. World Customs Journal, vol. 4, no. 1, pp. 15-21. ISSN: 1834-6707 (Print) 1834-6715 (Online). Retrieved from: https://worldcustomsjournal.org/Archives/Volume\%204\%2C\%20Number\%201\%20(Mar\%202 010)/00\%20Complete\%20Issue\%20WCJ_Volume_4_Number_1.pdf (accessed 12 Jan. 2020). (in Ukrainian)

${ }^{11}$ Hrytsiak I. A., Dzvinchuk D. I. (ed.) (2013) Yevropeiska intehratsiia : navchalnyi posibnyk dlia studentiv vyshchykh navchalnykh zakladiv ta slukhachiv mahisterskoi pidhotovky za napriamom «Derzhavne upravlinnia» [European integration: a textbook]. IvanoFrankivsk: Misto NV, 464 p. (in Ukrainian)

${ }^{12}$ Melnykov O. H. (2011) Derzhavne upravlinnia u sferi prykordonnoi bezpeky v umovakh yevropeiskoi intehratsii Ukrainy [Public administration in the sphere of border security in terms of Ukraine European integration] (PhD Thesis), National Academy of Public Administration the President of Ukraine, p. 234. (in Ukrainian)

${ }^{13}$ European Commission (EC) (2007) Guidelines for Integrated Border Management in the Western Balkans (2004, update: 2007). Retrieved from: https://www.legislationline.org/ documents/id/16809 (accessed 12 Jan. 2020). (in Ukrainian)

${ }^{14}$ Mizhnarodnyi dokument vid 22.11.2010 (2010) Bezvizovyi dialoh mizh Ukrainoiu ta YeS. Plan dii z liberalizatsii vizovoho rezhymu [Visa-free dialogue between Ukraine and the EU. Visa Liberalization Action Plan]. Retrieved from: https://zakon.rada.gov.ua/laws/show/ 984_001 (accessed 12 Jan. 2020). (in Ukrainian)
} 
as sufficient financial and human resources in the field of border management;

implementation of training programmes and adoption of anti-corruption codes of ethics that directly affect border officials, customs officials and other officials involved in border management;

and at the second stage (criteria for effective implementation):

ensuring adequate infrastructure, technical equipment, IT-technologies, financial and human resources in accordance with the adopted Strategy of IBM; effective implementation of training programs and anti-corruption measures;

improvement of interagency cooperation (including exchange of information between the border service and law enforcement agencies), international cooperation, especially the implementation of Working agreements with Frontex.

The basis for the implementation of the BSG is a coordinated and harmonized activity between all relevant authorities and services responsible for border security and trade facilitation (these are all agencies responsible for combating cross-border crime, border control, customs procedures, traffic safety, terrorist, migration and other types of security $)^{15,16,17}$.

All this indicates an increase in the scale of border activities, its network nature and a significant increase in the capacity of the BSG system, built on the IBM principles.

It should be pointed out that the expansion of border management inevitably leads to the emergence of new factors that can cause (especially in the early stages of the implementation of the BSG system) significant difficulties in management and, accordingly, lead to the leveling of the effectiveness of the entire BSG mechanism. The reasons for such difficulties are the following:

${ }^{15}$ Varga Ja., Kupriyenko D., Mironau D., Gaspar Z. (2015) Methodological approach to developing national differentiated training in integrated border management in Eastern Partnership countries. Magyar rendészet: a Nemzeti Közszolgálati Egyetem Rendészettudományi Karának szakmai, tudományos folyóirata, vol. XV/3, pp. 111-120. ISSN 1586-2895. Retrieved from: https://matarka.hu/nyomtat.php (accessed 12 Jan. 2020). (in English)

${ }^{16}$ Rozporiadzhennia Kabinetu Ministriv Ukrainy vid 15.11.2017 № 1023-r (2017) Pro skhvalennia Stratehii rozvytku orhaniv systemy Ministerstva vnutrishnikh sprav na period do 2020 roku [On approval of the Strategy of development of the bodies of the Ministry of Internal Affairs system for the period up to 2020]: Retrieved from: https://zakon.rada.gov.ua/laws/show/ 1023-2017-\%D1\%80 (accessed 12 Jan. 2020). (in Ukrainian)

${ }^{17}$ European Commission (EC) (2007) Guidelines for Integrated Border Management in the Western Balkans (2004, update: 2007). Retrieved from: https://www.legislationline.org/ documents/id/16809 (accessed 12 Jan. 2020). (in Ukrainian) 
increasing the number of entities that must provide border security according to a single plan;

intensification of planning and implementation of joint activities by border security guaranteeing entities (hereinafter - BSGE);

strengthening cooperation with international organizations (e.g. INTERPOL, Europol, Frontex Agency, International Organization for Migration (IOM), International Centre for Migration Policy Development (ICMPD), World border organization (BORDERPOL), World Customs Organization (WCO), etc.) as well as other stakeholders (carriers/operators, public, etc.).

In turn, these features lead to new higher requirements for personnel, because in the framework of the issue under consideration, the human factor is the most significant in terms of its influence on the possibility of using the BSG potential. In this regard, BSGE are obliged to pay considerable attention to the selection, training and motivation of personnel.

\section{Literature review}

A significant amount of research in various fields of social and humanitarian knowledge is devoted to the study of personnel management issues. The fundamental foundations of the problem are laid in the works of well-known scientists in the field of European integration, motivation, social management, management of the organization and the like. In modern research on the selection, training and motivation of personnel of organizations, the main attention is focused on the importance of using a unified approach, which contributes to the interaction of structures in various spheres of public life, including in the field of IBM as an innovative BSG mechanism $^{18,19,20,21}$.

At the same time, the results of the analysis of these studies, as well as the experience of training in BSG allow us to assert that:

${ }^{18}$ EuropeAid Cooperation Office (2010) Guidelines for Integrated Border Management in European Commission External Cooperation. Brussels, 152 p. Retrieved from: https://europa.eu/capacity4dev/file/21153/download?token=31OSGDjf (accessed 12 Jan. 2020). (in English)

${ }^{19}$ Frontex Agency (2012) Common Core Curriculum. EU Border Guard Basic Training. Warsaw, 104 p. Retrieved from: http://www.statewatch.org/news/2012/mar/frontex-ccctraining.pdf (accessed 12 Jan. 2020). (in English)

${ }^{20}$ Organization for Security and Cooperation in Europe (OSCE), United Nations Economic Commission for Europe (UNECE) (2012) Handbook of Best Practices at Border Crossings - A Trade and Transport Facilitation Perspective. Luxembourg: Imprimerie Centrale S.A., 268 p. ISBN: 978-3-9502218-8-6. Retrieved from: https://www.osce.org/secretariat/ 88238?download=true (accessed 12 Jan. 2020). (in English)

${ }^{21}$ Vajta I., Varga Ya. (2007) A Schengeni Határellenőrzési Kódex. E-Learning tananyag. Társszerzö. IRM Oktatási Föigazgatóság. (in Hungarian) 
(a) the issues of recruitment and motivation of personnel have been studied in depth and widely disclosed, and the selection and adaptation of rational approaches among them in the interests of border security does not cause difficulties;

b) issues related to scientific and methodological support and teaching methods for the formation and teaching of a training course on BSG have certain features, namely:

there are training and methodological materials on BSG developed by different departments, educational institutions and international organizations (textbooks, manuals, lectures, distance learning programs), however, they are usually either used on the principle of "all for all", or, in response to departmental interests, are highly specialized, internally oriented, and this can lead to a violation of the principle of "consistency" of knowledge in the general environment of training of personnel for BSGE;

the most complex and responsible issues are the formation of the educational content of disciplines(s), the distribution of educational time by forms and types of classes, as well as on individual issues, the justification of the necessary time for the study of the discipline;

noticeable distortions of information (through the gap in theory and practice and hierarchy of decision-making system), as well as significant temporal inertia from the moment of actual changes taking place in the field of BSG to the use in the field of education;

there are no scientific materials devoted to the study of the problem of formation of the training course and instilling competence to BSG.

Thus, these signs illustrate high probability of inharmoniousness of the system of training (education) of personnel for the BSG sphere, which, in turn, creates high risks of insufficient provision of national and international border interests. Taking this into account, the issue of developing an appropriate system of training becomes relevant, taking into account the features of the conceptual design of the training system in the BSG field. At the same time, the results that are expected to be achieved should ensure the formation of the competence of all personnel in the BSG field according to a single plan and to the required extent.

\section{Materials and methods}

According to the results of the analysis of works, in particular ${ }^{22}$, it is possible to develop a system of training using the capabilities of competence

${ }^{22}$ Blauberg I. V., Yudin E. G. (1973) Stanovlenie i suschnost sistemnogo podhoda [The system approach's formation and essence]. Moscow: NAUKA, 270 p. Retrieved from: http://tlf.msk.ru/school/Blauberg.pdf (accessed 12 Jan. 2020). (in USSR) 
and system approaches. In the aspect of our research the following characteristic features of competence approach in education (professional training) are of the greatest interest:

1) strengthening of practical orientation of training, its focus on future professional activity (that is, the shift of emphasis from the accumulation of normative certain knowledge and skills to the formation and development of future professionals the ability to act effectively in practice);

2) significant improvement of adaptation of young employees to job requirements with a predetermined (in the process of training) list of competencies and modeling of job situations;

3) the possibility to justify the system of program-target quality management of professional training.

In turn, the system approach is the main, generic scientific method of analysis of any studied pedagogical phenomenon and therefore it can be interpreted as a methodological direction, the task of which is to develop principles, methods and means of studying objects, including those relating to the system of training in the BSG field.

To develop a training system based on competence-based and systematic approaches, it is necessary to form its future desired image, which can be set in the form of certain requirements.

The first (main) - the set of competencies of the personnel of all BSGE of the should provide an effective solution to all problems of BSG.

Second - the competence of certain categories of BSGE personnel should be formed in the part that concerns them.

Third, the personnel of all BSGE categories should have systematic understanding of the activities of other entities.

Fourth - the content of the training system should be kept up to date (that is, changes in the BSG field should be delivered to the education sector without distortion and with minimal delay).

In our opinion, it is possible to develop a model of the training system that meets reasonable requirements, acting on the following methodology:

I. Organization of work on the formation of the training system:

1. The national coordination center of BSG on the basis of analysis of normative-legal base should identify the full range of BSGE of and initiate the establishment of a working group composed of experts-representatives and consultants - the leading experts in the BSG field of the relevant international and foreign organizations, to implement a scheme shown in the figure (numbers indicate the stages of the methodology).

II. Formation of training content and structure of its provision:

2. Identify the tasks that need to be solved to achieve the goals of BSG at each level (local, regional, national, interstate, international). 
3. On the basis of tasks to formulate all basic competences which the BSGE personnel for their successful performance (ensuring) has to have. It is also important to determine which of them are private (specific) for each BSG level, and which are common and the basis for other competencies (for example, communication skills, knowledge of foreign languages).

4. Define within entities the nomenclature of categories (positions) of the personnel which duties include accomplishment of BSG tasks.

5. Define personal competencies for each category of personnel and the level/degree of involvement of personnel in the performance of specific tasks).

6. To form a differentiated national training program for the training of BSG personnel (hereinafter - DNTP BSG) as a set of united by a single idea of especial training programs (hereinafter - TP) for different categories of personnel, as well as all employees of the BSGE. For effective application, timely monitoring of the relevance of competencies and continuous improvement, the mandatory elements of the program should be:

6.1. Informative part:

- recommended frequency of DNTP BSG monitoring;

- general methodology for the formation of DNTP BSG;

- customers of personnel - BSGE (contact information);

- educational / training institutions/centres (ETIC) (contact information), where the recruitment of personnel for each of the BSGE is carried out; their subordination to a higher authority (contact information);

- mechanisms to influence the adoption of especial BSG curricula for teaching (the Ministry of Education, the BSGE etc., their contact information).

6.2. Content relating to the composition and support of up-to-date state of TP of BSG:

- separate training programs to BSG for different categories of personnel, as well as all employees of the BSGE in the system of training, retraining, advanced training), indicating the technology of training (recommended forms and types of classes, effective methods, necessary educational and material base, etc);

- the results of the audit of training programs that already exist in the ETIC and provide for the formation of competencies in the BSG field, indicating the qualities that they form and those that do not form; the procedure for monitoring and making changes;

- the procedure for the final certification of specialists after the completion of the training program.

6.3. Requirements for teachers in the BSG field (scientific and pedagogical personnel, coaches, instructors, animators), recommendations for their training. Database of necessary data about them. 
6.4. The order to bring information to ETIC, which is preparing personnel for the BSGE, the web address of the resource DNTP BSG (website/portal/information system or relevant tab on the website), the procedure of maintenance and access to information.

6.5. The procedure for maintaining feedback:

- the procedure for the participation of personnel customers in the BSG field in the planning of joint exercises and certification of specialists;

- procedure for selection of candidates for work/service in the BSG field;

- the procedure and results of monitoring the activities of the personnel of the BSGE, which has been trained in BSG TP, with the allocation and categorizing of shortcomings in training (similar to the risk analysis: the scale of the shortage, the probability of occurrence, possible damage). The procedure for their elimination due to changes in the TP of BSG;

- the procedure for maintaining feedback with: ETIC, teachers in the BSG field, BSGE and their experts, with graduates of ETIC.

III. Implementation of training system:

7. To prepare (to retrain, to train) teaching personnel, and also to create necessary educational and material base of ETIC.

8. To provide the teaching personnel with the necessary educational and methodological information on the basis of the web-resource of the DNTP BSG in time.

9. To introduce the TP of BSG in the educational process of the ETIC.

IV. Maintaining the training system:

10. To maintain up-to-date and continuous improvement of the training system to organize sustainable feedback in accordance with paragraph 6.5.

As can be seen from these stages, the organization, development, use and support of the training system in the BSG field is large-scale and objectively requires the involvement of various specialists, both educational and practical levels. In this regard, we have proposed an organizational model of the training system in the BSG field, which is presented in Fig. 1. 


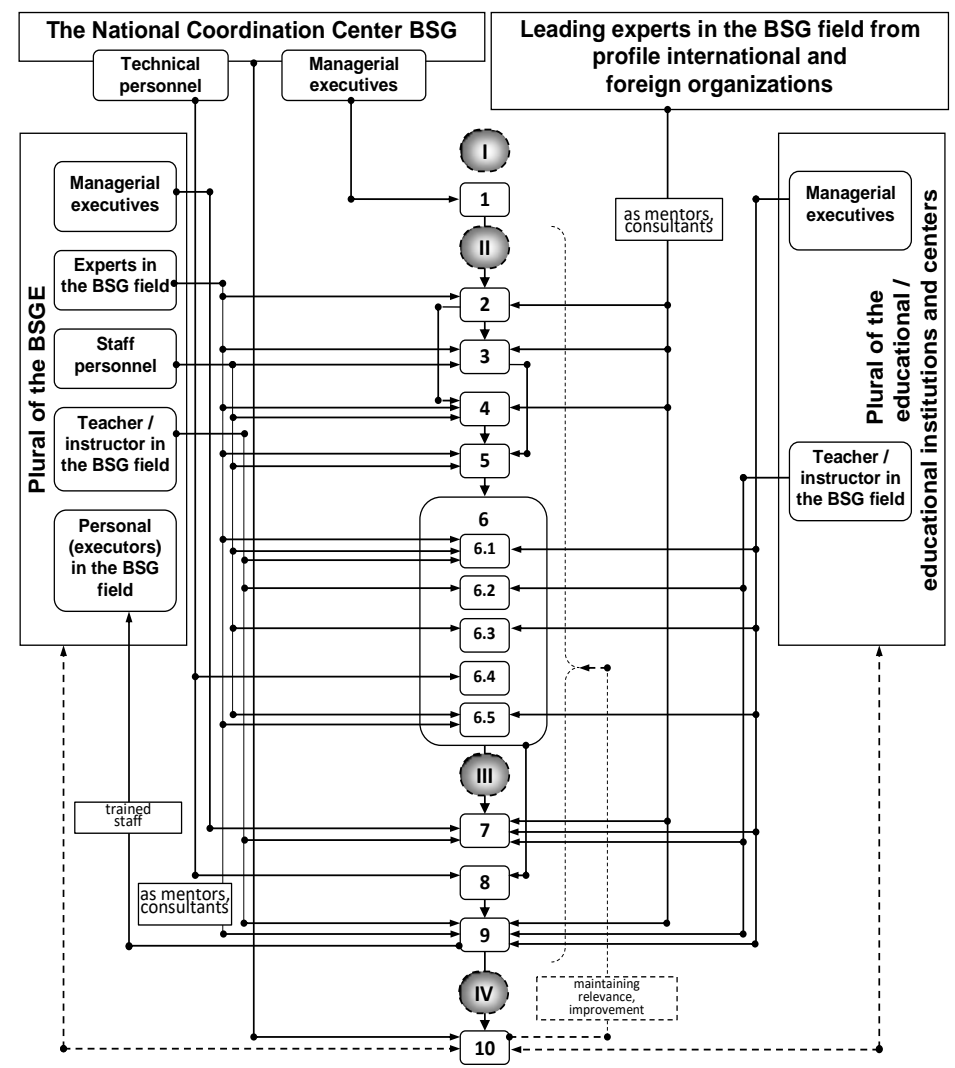

Fig. 1. Structural diagram of the organizational model of the system of coordinated training for joint actions of forces of security and defense sector of Ukraine of different affiliations in the context of an international cooperation (on the example of border security guaranteeing entities) ${ }^{23}$

For the practical implementation of these requirements, the model is proposed, the gist of which are reflected in the table 1.

${ }^{23}$ Varga Ya., Kupriyenko D., Mironov D. (2015) Kontseptualnoe proektirovanie sistemy podgotovki kadrov v sfere integrirovannogo upravleniya granitsami [Conceptual design of a training system in the field of integrated border management]. Zb. nauk. pr. SBGAU, Seriia : viiskovi ta tekhnichni nauky : naukove vydannia. Khmelnytskyi : NADPSU, no. 2 (64), pp. 6-23. (in English) 
Models of formation of generalized matrix of competencies of BSG personnel*

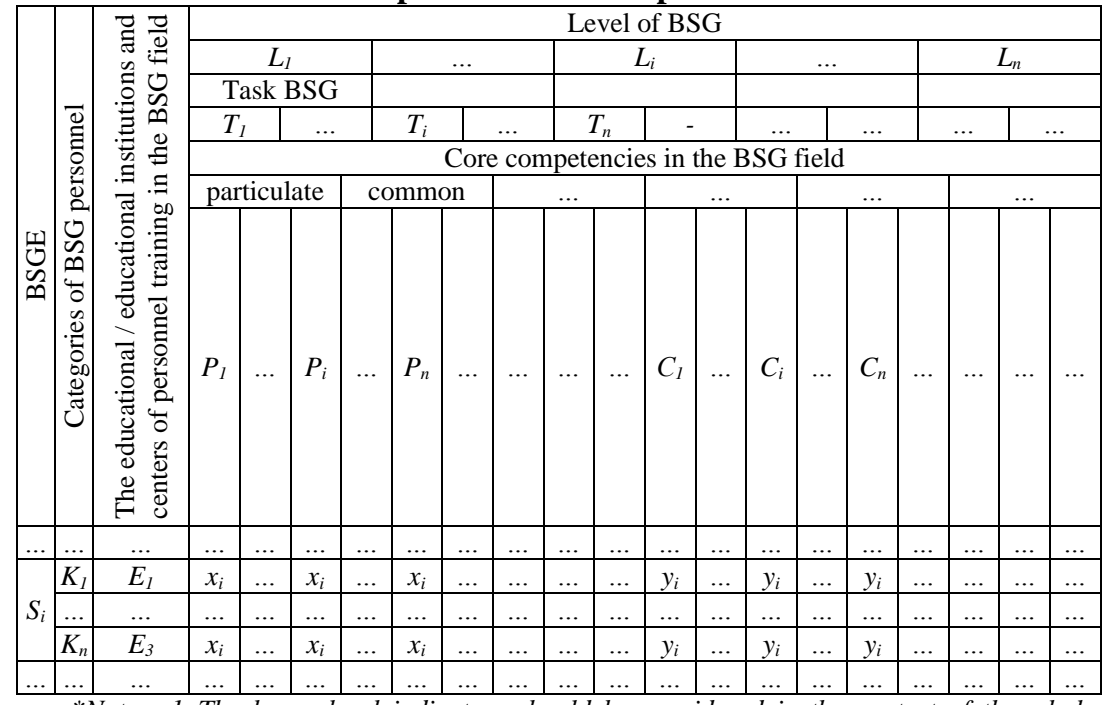

*Notes: 1. The lower level indicators should be considered in the context of the whole hierarchy of indicators, eg: correctly $-S_{1} / K_{3}$ (third category of first BSGE personnel) or $L_{3} / T_{2} / P_{4}$ (fourth competence of second task on the third BSG level); wrong $-C_{2}$ (second common competence).

2. $x_{i}=\left\{v_{1}, \ldots, v i, \ldots, v n\right\}$.

3. $y_{i}=\left\{l_{l}, \ldots, l_{i}, \ldots, l_{n}\right\}$, where $l$ (level) - is the conditional normalized levels of competence, starting from zero and beyond (e.g., English language skills

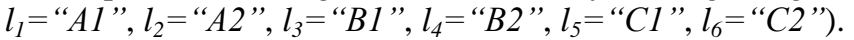

4. The main requirement for the DNTP BSG: "The set of competences of the personnel of all BSGE, that formulated in the DNTP BSG, should ensure that all BSG tasks are solved".

Creating a working design of especial TP for different categories of BSGE personnel (on the example of training of specialists of the State Border Guard Service of Ukraine on documents checking), is published in the article ${ }^{24}$.

24 Kupriyenko D. A., Sychevskyi Yu. O. (2015) Roboche proektuvannia okremoi navchalnoi prohramy zi skladu natsionalnoi dyferentsiiovanoi navchalnoi prohramy pidhotovky kadriv u sferi intehrovanoho upravlinnia kordonamy (na prykladi pidhotovky fakhivtsiv Derzhavnoi prykordonnoi sluzhby Ukrainy $\mathrm{z}$ perevirky dokumentiv) [Working design of a especial training program from the composition of the national differentiated training program for personnel in the integrated border management field (on the example of training of specialists of the State Border Service of Ukraine on document verification)]. Zb. nauk. pr. $S B G A U$, Seriia : viiskovi ta tekhnichni nauky : naukove vydannia. Khmelnytskyi : NADPSU, no. 4 (66), pp. 103-123. (in Ukrainian) 


\section{Results (proposals)}

Particular proposals for the development of the BSG system by preparing the forces of the BSGE for joint actions.

As for the professional training of forces of BSGE for joint action at the national level, first of all, the presence of the following prerequisites should be noted.

\section{Recommended national actions:}

1) in order to increase the responsibility and legal regulation to include in the Plan for the implementation of the IBM Strategy for the period up to 2025 activities related to the training of personnel of different categories in the field of BSG;

2) to implement a systematic approach to the training of personnel of the BSGE develop NDTP BSG;

3) to systematize: specific tasks that are solved in the field of BSG; necessary for the solution of competence; categories of personnel in the field of BSG; identification of educational / training institutions and centers in which training, retraining and advanced training is carried out;

4) to include in the Appendix to the diploma of education (or certificate of training) the competencies possessed by the graduate, including in the field of BSG (for example, on the model of the European practice Transcript of Records, conform Bologna);

5) to the BSGE coordinator to enter the site / portal/information system for NDTP of BSG, to define the corresponding order of support and access;

6) to conduct joint (interdepartmental) training of personnel of different categories and departments in the field of BSG and to introduce trained personnel into the system of departmental / interdepartmental multiplication;

7) to improve the mechanism of interaction of the personnel customers with educational / training institutions and centers;

8) in educational/training institutions and centers to determine the structural and logical links between disciplines that ensure the formation of competencies in the BSG field;

9) for especial lectures, it is advisable to invite qualified representatives of the BSGE (mainly - heads of different levels of management, prominent figures, leading experts, personnel who perform daily duties in the field of BSG, representatives of interacting bodies, scientific and pedagogical personnel from other educational / training institutions and centers);

10)in addition to the current system of training of scientific and pedagogical personnel, to explore the possibility and introduce periodic internships (up to 5 days) on the basis of other BSGE. 


\section{Recommended external support:}

1) to participate in the justification of partial training programs for the training of employees of specific categories;

2) provide organizational assistance in training of multipliers (selection and invitation of relevant experts from international organizations, EU and Eastern partnership countries);

3) to provide technical and financial support in the preparation of projects and activities for the development of a website / portal / information system for the NPTP of the BSG.

On preparation of forces of BSGE for joint actions at the interstate and international levels it is offered.

In the sphere of educational activities:

1) for the purpose of legal regulation of cooperation to conclude bilateral agreements or protocols between educational / educational institutions of BSGE of Ukraine with the relevant institutions of the EU and Eastern partnership States;

2) in order to obtain organizational, scientific, methodological and practical experience:

in the case of planning joint exercises by educational institutions of the EU or Eastern partnership countries, invite representatives of the entities of the educational (in particular, scientific and pedagogical personnel, adjuncts, doctoral students, master's students and cadets) and operational spheres;

to expand opportunities of foreign internships of scientific and pedagogical personnel, adjuncts, doctoral students, students and cadets of educational / training institutions of the BSGE through projects funded by the EU and the USA;

to study the content of the curricula and literature on the BSG (including the course and literature on the English language based on the BSG) developed in the EU and Eastern partnership States for bachelor, master and doctoral students. If necessary, to transfer them to the interested party (or exchange);

take an active part in international scientific conferences in the EU and Eastern partnership countries;

create and maintain up-to-date general catalogue of scientific publications available in educational institutions-signatories of the Memorandum of understanding and cooperation between educational institutions of a number of EU member States and Eastern partnership countries (list of publications, periodicity, procedure for submitting publications);

take an active part in joint research in the field of education and BSG, as well as the publication of joint articles; 
to take an active part in the training activities of the personnel training system of the EU and Eastern Partnership countries entities;

3 ) it is proposed to include in the Strategy provisions to intensify the involvement of international and European organizations (including IOM, OSCE, ICMPD, Frontex) in order to organize and conduct on the basis of the National Academy of the State Border Guard Service of Ukraine named after Bohdan Khmelnytskyi training courses (retraining, advanced training) of various categories of personnel in the interests of border security at the national and regional levels;

4) in order to improve the skills of the management of the BSGE to organize training for them in the relevant educational institutions/centers of the EU member states, as well as in the OSCE Border Management Staff College (R. Tajikistan);

5) after each significant event to issue for the beneficiary a document of a recommendatory nature signed by the Party that organized the event, the introduction of best practices. To organize a second meeting of the Parties after a specified period to discuss the results of the implementation and the circumstances preventing it;

6) for the purpose of rapprochement to take part in sports and cultural events, including professional holidays, held in the EU and the Eastern partnership.

\section{SUMMARY}

Thus, the method of coordinated training for joint actions of forces of security and defense sector of Ukraine of different affiliations in the context of an international cooperation, which allows to carry out conceptual, working and organizational design of system of training of specific categories of the personnel of forces of security and defense sector according to the unified plan and in necessary volume was developed. The method is based on the models that are formed on the basis of the application of competence and system approaches to the training of personnel of security and defense sector, namely: models of differentiated training program on security and defense; organizational model of the system of training for joint actions of forces of security and defense sector; models of formation of generalized matrix of competencies of personnel of forces of security and defense sector.

The solution of the problem of coordinated preparation of forces for joint actions will allow to increase the efficiency of functioning and development of security and defense sector both at the national, and at the international level.

The formed image of the system of personnel training, which is presented in the form of the following requirements: a) a set of competencies 
of personnel of all the security guaranteeing entities needs to provide an effective solution to all security guaranteeing tasks; b) the competence of the especial personnel categories of the security guaranteeing entities need to build on those aspects that concern them; c) personnel of all categories of the security guaranteeing entities needs to have system idea about the activities of other actors; d) the content of the training system need to keep up to date (i.e. changes in the security guaranteeing field, must enroll in education without distortion and with a delay).

\section{REFERENCES}

1. Shynkaruk O. M., Lysyi M. I., Kupriyenko D. A. (2019) Suchasnyi stan prykordonnoho bezpekovoho seredovyshcha Ukrainy [The modern state of the border security environment of Ukraine]. Scientific Works of Kharkiv National Air Force University, Vol. 3(61), pp. 135-145. https:// doi.org/10.30748/zhups.2019.61.17 (in Ukrainian)

2. Rozporiadzhennia Kabinetu Ministriv Ukrainy vid 24 lypnia 2019 r. № 687-r (2019) Pro skhvalennia Stratehii intehrovanoho upravlinnia kordonamy na period do 2025 roku [On the approval of the Integrated Border Management Strategy for the period up to 2025]. Retrieved from: https://zakon.rada.gov.ua/laws/show/687-2019-\%D1\%80 (accessed 12 Jan. 2020). (in Ukrainian)

3. Mizhnarodnyi dokument vid 27.06.2014 (2014) Uhoda pro asotsiatsiiu mizh Ukrainoiu, z odnoho boku, ta Yevropeiskym Soiuzom, Yevropeiskym spivtovarystvom $z$ atomnoi enerhii $i$ yikhnimy derzhavamy-chlenamy, $\mathrm{z}$ druhoho boku [Association Agreement between Ukraine, of the one part, and the European Union, the European Atomic Energy Community and their Member States, of the other part]. Retrieved from: https://zakon.rada.gov.ua/go/984_011 (accessed 12 Jan. 2020). (in Ukrainian)

4. Ukaz Prezydenta Ukrainy vid 26.05.2015 № 287/2015 (2015) Pro rishennia Rady natsionalnoi bezpeky i oborony Ukrainy vid 6 travnia 2015 roku „Pro Stratehiiu natsionalnoi bezpeky Ukrainy” [On the decision of the National Security and Defense Council of Ukraine of May 6, 2015 «On the National Security Strategy of Ukraine»]. Retrieved from: https://zakon.rada.gov.ua/go/287/2015 (accessed 12 Jan. 2020). (in Ukrainian)

5. Bodruk O.S. (2001) Struktury voiennoi bezpeky: natsionalnyi ta mizhnarodnyi aspekty : monohrafiia [Military security structures: national and international aspects: monograph]. Kyiv : NIPMB, 300 p. (in Ukrainian)

6. Brezhnieva T., Yizhak O., Shevtsov A. (2003) Yevroatlantychna intehratsiia Ukrainy: viiskovo-politychni aspekty : monohrafiia [Ukraine's 
Euro-Atlantic integration: military-political aspects: monograph]. Dnipropetrovsk : Porohy, 160 p. ISBN: 966-525-424-3 (in Ukrainian)

7. Communication to the Council and the European Parliament. Towards integrated management of the external borders of the member states of the European Union. Brussels, 7 May 2002, COM(2002) 0233 final, $28 \mathrm{p}$. Retrieved from: https://eur-lex.europa.eu/legalcontent/EN/TXT/?uri=celex:52002DC0233 (accessed 12 Jan. 2020). (in English)

8. EuropeAid (2010) Cooperation Office Guidelines for Integrated Border Management in European Commission External Cooperation. Brussels, 152 p. Retrieved from: https://europa.eu/capacity4dev/file/21153/ download?token=31OSGDjf (accessed 12 Jan. 2020). (in English)

9. McLinden G., Fanta E., Widdowson D. and Doyle Th. (2010) Border Management Modernization: A Practical Guide for Reformers : conference edition. Washington, D.C.: The World Bank. Retrieved from: https://pdfs.semanticscholar.org/6043/4817c84ea9a4d741874fc98301b8bc2b b843.pdf (in English)

10. Doyle T. (2010) Collaborative border management. World Customs Journal, vol. 4, no. 1, pp. 15-21. ISSN: 1834-6707 (Print) 1834-6715 (Online). Retrieved from: https://worldcustomsjournal.org/Archives/Volume $\% 204 \% 2$ C\%20Number\%201\%20(Mar\%202010)/00\%20Complete\%20Issue \%20WCJ_Volume_4_Number_1.pdf (accessed 12 Jan. 2020). (in English)

11. Hrytsiak I. A., Dzvinchuk D. I. (ed.) (2013) Yevropeiska intehratsiia : navchalnyi posibnyk dlia studentiv vyshchykh navchalnykh zakladiv ta slukhachiv mahisterskoi pidhotovky za napriamom "Derzhavne upravlinnia" [European integration: a textbook]. Ivano-Frankivsk: Misto NV, 464 p. (in Ukrainian)

12. Melnykov O. H. (2011) Derzhavne upravlinnia u sferi prykordonnoi bezpeky $\mathrm{v}$ umovakh yevropeiskoi intehratsii Ukrainy [Public administration in the sphere of border security in terms of Ukraine European integration] (PhD Thesis), National Academy of Public Administration. (in Ukrainian)

13. European Commission (EC) (2007) Guidelines for Integrated Border Management in the Western Balkans (2004, update: 2007). Retrieved from: https://www.legislationline.org/documents/id/16809 (accessed 12 Jan. 2020). (in English)

14. Mizhnarodnyi dokument vid 22.11.2010 (2010) Bezvizovyi dialoh mizh Ukrainoiu ta YeS. Plan dii z liberalizatsii vizovoho rezhymu [Visa-free dialogue between Ukraine and the EU. Visa Liberalization Action Plan]. Retrieved from: https://zakon.rada.gov.ua/laws/show/984_001 (accessed 12 Jan. 2020). (in Ukrainian)

15. Varga Ja., Kupriyenko D., Mironau D., Gaspar Z. (2015) Methodological approach to developing national differentiated training in 
integrated border management in Eastern Partnership countries. Magyar rendészet: a Nemzeti Közszolgálati Egyetem Rendészettudományi Karának szakmai, tudományos folyóirata, vol. XV/3, pp. 111-120. ISSN 1586-2895. Retrieved from: https://matarka.hu/nyomtat.php (accessed 12 Jan. 2020). (in English)

16. Rozporiadzhennia Kabinetu Ministriv Ukrainy vid 15.11.2017 № 1023-r (2017) Pro skhvalennia Stratehii rozvytku orhaniv systemy Ministerstva vnutrishnikh sprav na period do 2020 roku [On approval of the Strategy of development of the bodies of the Ministry of Internal Affairs system for the period up to 2020]: Retrieved from: https://zakon.rada.gov.ua/laws/show/1023-2017-\%D1\%80 (accessed 12 Jan. 2020). (in Ukrainian)

17. European Commission (EC) (2007) Guidelines for Integrated Border Management in the Western Balkans (2004, update: 2007). Retrieved from: https://www.legislationline.org/documents/id/16809 (accessed 12 Jan. 2020). (in English)

18. EuropeAid Cooperation Office (2010) Guidelines for Integrated Border Management in European Commission External Cooperation. Brussels, 152 p. Retrieved from: https://europa.eu/capacity4dev/file/ 21153/download?token=31OSGDjf (accessed 12 Jan. 2020). (in English)

19. Frontex Agency (2012) Common Core Curriculum. EU Border Guard Basic Training. Warsaw, 104 p. Retrieved from: http://www.statewatch.org/news/2012/mar/frontex-ccc-training.pdf (accessed 12 Jan. 2020). (in English)

20. Organization for Security and Cooperation in Europe (OSCE), United Nations Economic Commission for Europe (UNECE) (2012) Handbook of Best Practices at Border Crossings - A Trade and Transport Facilitation Perspective. Luxembourg: Imprimerie Centrale S.A., 268 p. ISBN: 978-39502218-8-6. Retrieved from: https://www.osce.org/secretariat/88238? download=true (accessed 12 Jan. 2020). (in English)

21. Vajta I., Varga Ya. (2007) A Schengeni Határellenőrzési Kódex. ELearning tananyag. Társszerzö. IRM Oktatási Föigazgatóság. (in Hungarian)

22. Blauberg I. V., Yudin E. G. (1973) Stanovlenie i suschnost sistemnogo podhoda [The system approach's formation and essence]. Moscow : NAUKA, 270 p. Retrieved from: http://tlf.msk.ru/school/ Blauberg.pdf (accessed 12 Jan. 2020). (in USSR)

23. Varga Ya., Kupriyenko D., Mironov D. (2015) Kontseptualnoe proektirovanie sistemy podgotovki kadrov $\mathrm{V}$ sfere integrirovannogo upravleniya granitsami [Conceptual design of a training system in the field of integrated border management]. Zb. nauk. pr. SBGAU, Seriia : viiskovi ta 
tekhnichni nauky : naukove vydannia. Khmelnytskyi : NADPSU, no. 2 (64), pp. 6-23. (in Ukrainian)

24. Kupriyenko D. A., Sychevskyi Yu. O. (2015) Roboche proektuvannia okremoi navchalnoi prohramy zi skladu natsionalnoi dyferentsiiovanoi navchalnoi prohramy pidhotovky kadriv u sferi intehrovanoho upravlinnia kordonamy (na prykladi pidhotovky fakhivtsiv Derzhavnoi prykordonnoi sluzhby Ukrainy z perevirky dokumentiv) [Working design of a especial training program from the composition of the national differentiated training program for personnel in the integrated border management field (on the example of training of specialists of the State Border Service of Ukraine on document verification)]. Zb. nauk. pr. SBGAU, Seriia : viiskovi ta tekhnichni nauky : naukove vydannia. Khmelnytskyi : NADPSU, no. 4 (66), pp. 103-123. (in Ukrainian)

Information about the author:

Dmytro Kupriyenko,

Deputy Dean for Academic Affairs

of the Faculty of training Managerial executives, The National Academy of the State Border Guard Service of Ukraine named after Bohdan Khmelnytskyi

46 Shevhenka str., Khmelnytskyi, 29007, Ukraine

ORCID ID: orcid.org/0000-0002-4086-1310 


\section{METHOD OF ASSESSMENT OF THE STATE OF INFORMATIONAL AND ANALYTICAL ACTIVITY OF OPERATING UNITS OF THE STATE BORDER GUARD SERVICE OF UKRAINE}

\section{Oleh Farion}

\section{INTRODUCTION}

The reliability of protection the state border is achieved by the high efficiency of the operational and service activity of organs and units of the State Border Guard Service of Ukraine (hereinafter - SBGSU), including search and operational units (hereinafter referred to as operational units) ${ }^{1}$. To accomplish this, the operational units of the SBGS of Ukraine carry out a set of measures aimed, primarily, at the discovery, collection (extraction), processing, storage, and exchanging of information ${ }^{2}$. These activities in the aggregate constitute information and analytical activity (hereinafter - IAA) according to R. Lyashuk and O. Farion ${ }^{3}$ (Lyashuk \& Farion, 2010a). Such activity, under the influence of changes in the operational situation at the state border and other factors may, to some extent, satisfy or not the heterogeneous needs of the operational units of the SBGS of Ukraine.

The results of the operational and service activity of operational units'activity of the State Border Guard Service of Ukraine indicate that the rapid nature of changes in the operational and criminogenic circumstance limits the amount of time available for the complete collection of the situation data, their comprehensive analysis and preparation of analytical products (for instance, distribution of forces and means, decision making) ${ }^{4}$.

${ }^{1}$ Pro derzhavnij kordon Ukrayini (1992) [About the State Border of Ukraine] : Zakon Ukrayini vid 04.11.1991 r. № 1777-XII / Vidomosti Verhovnoyi Radi Ukrayini. № 2. St. 5 (z nastupnimi zminami ta dopovnennyami). (in Ukrainian)

${ }_{2}$ Pro operativno-rozshukovu diyalnist (1992) [About the operative-search activity] : zakon Ukrayini vid 18.02.1992 r. № 2135-XII. Data onovlennya: 28.08.2019. URL: http://zakonl.rada.gov.ua/laws/show/2135-12/page (data zvernennya: 12.09.2019). (in Ukrainian)

3 Lyashuk R. M., Farion O. B. (2019) Informacijno-analitichna diyalnist operativnorozshukovih pidrozdiliv Derzhavnoyi prikordonnoyi sluzhbi Ukrayini [Information and analytical activity of the operational and search units of the State Border Guard Service of Ukraine]. Zb. nauk. pr. Hmelnickij : NA DPSU, no. 30, pp. 62-75. (in Ukrainian)

${ }^{4}$ Rezultati operativno-sluzhdbovoyi diyalnosti Derzhavnoyi prikordonnoyi sluzhbi Ukrayini (2019) [Results of the operational and service activities of the State Border Guard Service of Ukraine]. Data onovlennya: 10.12.2019. URL:https://dpsu.gov.ua/ua/photo-infografika-rezultati-operativnosluzhbovoi-diyalnosti-za-2019-rik/(data zvernennya: 12.12.2019). (in Ukrainian) 
Thus, how well the data received will be in line with the operational situation and processed in a qualitative manner, so timely and well-grounded the management decision will be made and the response measures effectively implemented (for example, prevention and/or cessation of illegal activities, detention of offenders).

So, the final result of activity of operational units of the border guarding depends, first of all, on efficiency of IAA, the condition of which needs to be determined for further adjustment, if necessary. Therefore, the need to address the issue of assessing the status of IAA operational units of the SBGS of Ukraine determines the relevance of the study.

\section{Aalysis of recent publications}

Some results of the study of IAA organs and units of the SBGS of Ukraine are revealed in the scientific works of B. M. Alekseyenko, A. S. Androshchuk, Ya. S. Galanyuk, Yu. B. Ivashkov, I. S. Katerynchuk, D. A. Kuprienko, G. A. Magas, Yu. V. Mazur, A. V. Makhniuk, A. B. Misyka, O. V. Mikhailenko, V. O. Nazarenko, V. O. Subotina, P. O. Tsigikala, O. M. Shinkaruk and other scientists. They have proposed a number of approaches to improve management of decision-making processes, substantiated individual views on the usage of forces and tools to obtain information, developed a number of models and techniques for upgrading border security, considered the improvement of information and analytical work in the operational and other units SBGS of Ukraine. In the course of studying the content of articles of domestic scientists who have considered the issues of IAA in the bodies and units of the SBGS and law enforcement agencies of Ukraine, a lack of methodology is defined for assessing the status of IAA, and the available scientific and methodological tools for assessing these activities in the operational units of the SBGS of Ukraine do not take into account a set of indicators that characterizes the assessment. Thus, the lack of scientific development on the topic defined determines the urgency of this scientific research.

The purpose of the article is to develop a methodology for assessing the status of IAA of operational units of the SBGS of Ukraine.

\section{Outline of the Main Research Material}

Considering that the solution of the issues of timely obtaining the situation data and their effective analysis by the forces and means of the 
operational units of the SBGS of Ukraine is entrusted to the IAA ${ }^{5}$, the object of modeling is the specified activity.

The subject of modeling is the processes of collecting (extracting) information on the operational and criminogenic situation at the state border, analysis of received and available data, organization of IAA in the operational unit of the SBGS of Ukraine.

The process of obtaining, collecting (extracting) by the opportunities and means of the operational unit information about the situation on the state border, in particular illegal activities, includes:

collecting and retrieving information about illicit events and phenomena that may indicate, through information characteristics, the committed crime or its preparing according to A. Voytovuch and O. Farion ${ }^{6}$ (Voytovuch \& Farion, 2010a); according to P. Tsygikal and O. Farion ${ }^{7}$ (Tsygikal \& Farion, 2017a);

monitoring of Internet resources available in operational and interactive units of databases O. Farion ${ }^{8}$ (Farion, 2018);

determining the degree of importance of the data received for prompt response to them O. Farion ${ }^{9}$ (Farion, 2013a);

5 Pro zatverdzhennya Polozhennya pro operativno-rozshukovij viddil organu ohoroni derzhavnogo kordonu (2015) [On approval of the Regulation on the Operational and Investigative Division of the State Border Protection Body] : nakaz Ministerstva vnutrishnih sprav Ukrayini vid 02.02.2015 № 118 URL: https://zakon.rada.gov.ua/laws/show/z0187-15 (data zvernennya: 12.09.2019). (in Ukrainian)

6 Vojtovich A. I., Farion O. B. (2010) Poryadok viznachennya prioritetu protipravnih situacij, sho vinikayut na richkovij dilyanci derzhavnogo kordonu [The procedure for determining the priority of unlawful situations occurring at the river section of the state border]. Zb. nauk. pr. : trudi akademiyi. Kiev : NAOU, no. 6(99), pp. 98-102. (in Ukrainian)

7 Cigikal P. O., Farion O. B. (2017) Model rozpiznavannya zlochiniv operativnorozshukovim viddilom Derzhavnoyi prikordonnoyi sluzhbi Ukrayini dlya svoyechasnogo yih poperedzhennya, viyavlennya i pripinennya [Model of crime detection by the Operational Investigation Department of the State Border Guard Service of Ukraine for their timely prevention, detection and termination]. Zb. nauk. pr. Hmelnickij : NA DPSU, no. 1(71), pp. 238-255. (in Ukrainian)

${ }^{8}$ Farion O. B. (2018) Okremi prijomi i sposobi monitoringu prihovanih resursiv Internetu, nakopichennya informaciyi ta doslidzhennya oznak protipravnoyi diyalnosti iz zastosuvannyam kriminalnogo analizu [Separate techniques and methods for monitoring hidden Internet resources, accumulating information and investigating signs of criminal activity using criminal analysis]. Zb. nauk. pr. ser. Hmelnickij : NA DPSU, no. 29, pp. 119-130. (in Ukrainian)

${ }_{9}$ Farion O. B. (2013) Instrumentarij viznachennya tipu zagroz prikordonnij bezpeci v procesi provedennya strategichnogo kriminalnogo analizu operativno-rozshukovim pidrozdilom regionalnogo upravlinnya Derzhavnoyi prikordonnoyi sluzhbi Ukrayini [Toolkit for determining the type of border security threats in the process of strategic criminal analysis operational-search unit of the regional department of the State Border Service of Ukraine]. Zb. nauk. pr. ser. Hmelnickij : NA DPSU, no. 2(60) , pp. 212-218. (in Ukrainian) 
establishing a specific type of crime according to P. Tsygikal and O. Farion ${ }^{10}$ (Tsygikal \& Farion, 2017b), in accordance with the provisions of the Criminal Code of Ukraine;

selection, if necessary, of information concerning further actions of criminals and / or persons (e.g., aide, carrier, financier), who assist them in committing a crime (e.g., paying the costs associated with committing a crime, accompanying illegal migrants to the state border), ways of committing a crime, changing the route of traffic, etc.

The process of analyzing received and available data includes:

primary analysis of data about events and other situations on the state border received (obtained) by the operational unit from available sources of information, or personally;

determining the priority of illegal situations;

systematization and converting the obtained data in a convenient form for use and also for conducting analytical research;

analytical study of available and operational data by forces and means of informational and analytical units, such as, for example, units of information-analytical support of operational-search activity, units of criminal analysis;

development of analytical products;

presenting (proving) the results of analysis to the customer or the management of the operational unit, other interested parties and cooperating structures.

At the same time, each of these processes must correspond to the level of organization that would allow to receive the necessary result in time to ensure the activity of the operational unit. The timeliness requirement is important for all IAA processes. Thus, the timeliness of a crime detection is determined by the degree (level) of correspondence of time moments since its committing to the receiving the information about it by the operational unit. The moment of committing a crime in the area of responsibility of the operational unit of the SBGS of Ukraine, unknown in advance, depends on the intent of the actions of criminals in committing a crime and their ability to achieve the goal. The moment of detection (recognition) of a crime is also unknown in advance, so it is a random variable and depends on the availability of sources of information at the site of the unlawful situation and

10 Cigikal P. O., Farion O. B. (2017) Model rozpiznavannya zlochiniv operativnorozshukovim viddilom Derzhavnoyi prikordonnoyi sluzhbi Ukrayini dlya svoyechasnogo yih poperedzhennya, viyavlennya i pripinennya [Model of crime detection by the Operational Investigation Department of the State Border Guard Service of Ukraine for their timely prevention, detection and termination]. Zb. nauk. pr. ser. Hmelnickij : NA DPSU, no. 1(71), pp. 238-255. (in Ukrainian) 
their ability to organize and transfer information to the authorized person or to the operational unit; from the ability to reliably recognize (identify) the type of crime on the basis of available evidence from sources of information.

Timeliness of analysis of received and available data is determined by the degree of accordance of moments from the receipt of information for analytical research to the development of analytical products and the presentation (demonstrating) of the results of analysis to the customer or the management of the operational unit, other interested persons and interacting structures. The moment of the receiving the information required for analytical research depends on the content of the data obtained, its accuracy, completeness and relevance, which in the aggregate must satisfy the needs for qualitative analytical research. The moment to develop analytical products and to present (demonstrate) the results of analysis to the customer depends on the achievement of the goal of analytical research.

The timeliness of the organization of the IAA operational units of the SBGS of Ukraine is determined by the degree of correspondence of moments from the formation of the purpose of the IAA to the setting of tasks for the forces and means of the operational unit to achieve it. That is, the tasks of obtaining information, analyzing it and presenting (demonstrating) the results of analysis to the customer (for example, to the head of the operational unit, other interested persons, interacting structures).

The purpose of the modeling is V. Gorodnov ${ }^{11}$ (Gorodnov, 2004a):

1) evaluation of the IAA state of the operational unit of the STGS of Ukraine;

2) decision making on formation of rational composition of forces and means of obtaining information (networks sources of information, including agent), effective mechanism of information analysis and production of analytical products to timely provide the needs of operational and service activities of the operational unit.

So, based on the study of the content of the subject area of the study, it is defined that the assessment of the IAA state of a separate operational unit of the SBGS of Ukraine is determined by a set of marks:

the status of implementation of measures aimed at obtaining (collecting, extracting) the situation data at the state border of Ukraine and in border areas;

11 Gorodnov V. P. (2004) Metodika ocenki effektivnosti variantov obespecheniya funkcionirovaniya sistemy raznorodnyh mnogoparametricheskih obektov razlichnoj vazhnosti [Methodology for assessing the effectiveness of operational options systems of heterogeneous multi-parameter objects of various importance]. Naukove vidannya Sistemi obrobki informaciyi. Harkiv : NANGU, no. 2, pp. 159-163 (in Russian) 
the status of implementation of analytical research aimed at the production (development) of the analytical product necessary to implementation the tasks assigned by the laws of Ukraine to the operational unit;

the status of the IAA organization in the operational unit of the SBGS of Ukraine.

In addition, to increase the objectivity of assessing the IAA status of the operational unit of the SBGS of Ukraine, it is necessary to take into account the coefficients of influence such factors as:

1. Group of factors of operational and criminogenic situation on the state border of Ukraine that influence the process of obtaining and results of information analysis in the process of IAA operational units according to A. Voytovuch and O. Farion ${ }^{12}$ (Voytovuch \& Farion, 2010b); P. Tsygikal ${ }^{13}$ (Tsygikal, 2017a): development of migration processes from risk countries, caused by conflicts of ethnic and confessional orientation and financial consequences of the crisis; development of activities of cross-border criminal groups specializing in smuggling of illegal migrants, trafficking in human beings and smuggling, development of activity transborder criminal groups which are specialized in transferring the illegal migrants, human trafficking and contraband; development of a support base among the residents of the border, further branching and improvement of tactics of criminal activity; existing threats of terrorist acts on the state border of Ukraine, their nature and prognosis for further development; the presence of foreign diasporas, the degree of involvement of their representatives in the establishment of channels of illegal migration and the legalization of illegal migrants; attempts to involve population of the border regions of Ukraine and neighboring states in the illegal activities, etc.

2. A group of factors that affect the logistics process IAA: the availability of technical means of obtaining information; the provision of operative means for special expenses; availability of technical means for analytical work; availability of special software; availability of communication facilities; availability of transport (its working conditions); availability of databases, etc.

${ }^{12}$ Vojtovich A. I., Farion O. B. (2010) Poryadok viznachennya prioritetu protipravnih situacij, sho vinikayut na richkovij dilyanci derzhavnogo kordonu [The procedure for determining the priority of unlawful situations occurring at the river section of the state border]. Zb. nauk. pr. : trudi akademiyi. Kiev : NAOU, no. 6 (99), pp. 98-102. (in Ukrainian)

${ }_{13}$ Cigikal P. O. (2017) Metodika formuvannya sistemi informacijnogo zabezpechennya operativno-rozshukovoyi diyalnosti Derzhavnoyi prikordonnoyi sluzhbi Ukrayini v umovah teritorialnoyi oboroni [Methods of Formation of Information Support System for Operational and Investigative Activity of the State Border Guard Service of Ukraine in Territorial Defense]. Shokvartalnij naukovij zhurnal Chest $i$ zakon. Harkiv : NANGU, no. 4 (63). 104 p. (in Ukrainian) 
3. A group of factors that influence the organization process IAA: staffing and security of the unit; professional training of staff; staff experience; term operational and service activity in the unit, etc.

4. Other factors.

The analysis IAA processes, the impact of these factors and results operational performance operating units form a group of indicators to characterize the properties and assessment of IAA in operational units to SBGS of Ukraine according to O. Farion ${ }^{14}$ (Farion, 2013b); P. Tsygikal ${ }^{15}$ (Tsygikal, 2017).

Table 1

\section{Aggregate indicators to assess the state of information and analytical activity of the operational unit of the State Border Guard Service of Ukraine}

\begin{tabular}{|l|l|l|l|}
\hline \multirow{2}{*}{ S/n } & \multicolumn{1}{|c|}{$\begin{array}{c}\text { Name } \\
\text { complex indicator }\end{array}$} & \multicolumn{1}{c|}{ Constituent elements } & \multirow{2}{*}{ Note } \\
\hline \multicolumn{3}{|c|}{ I. Indicators of assessment of the state of implementation of measures aimed at obtaining } \\
(collecting, extracting) data from the situation at the state border of Ukraine
\end{tabular}

${ }^{14}$ Farion O. B. (2013) Instrumentarij viznachennya tipu zagroz prikordonnij bezpeci $\mathrm{v}$ procesi provedennya strategichnogo kriminalnogo analizu operativno-rozshukovim pidrozdilom regionalnogo upravlinnya Derzhavnoyi prikordonnoyi sluzhbi Ukrayini [Toolkit for determining the type of border security threats in the process of strategic criminal analysis operational-search unit of the regional department of the State Border Service of Ukraine]. $Z b$. nauk. pr. Hmelnickij : NA DPSU, no. 2(60), pp. 212-218. (in Ukrainian)

${ }_{15}$ Tsygikal P. O. (2017) Obgruntuvannya sistemi chastkovih pokaznikiv formuvannya sistemi informacijnogo zabezpechennya operativno-rozshukovoyi diyalnosti Derzhavnoyi prikordonnoyi sluzhbi Ukrayini v umovah teritorialnoyi oboroni [Substantiation of the system of partial indicators of the formation of the system of information support of the operational and search activity of the State Border Guard Service of Ukraine in the conditions of territorial defense]. Zb. nauk. pr. K. : CNDI ZSU, no. 3(81), pp. 222-230. (in Ukrainian) 


\begin{tabular}{|c|c|c|c|}
\hline $\mathbf{S} / \mathbf{n}$ & $\begin{array}{c}\text { Name } \\
\text { complex indicator }\end{array}$ & Constituent elements & Note \\
\hline & \multirow[t]{9}{*}{ operational unit } & $\begin{array}{l}\text { as part of the pre-trial } \\
\text { investigation }\end{array}$ & \\
\hline & & $\begin{array}{l}\text { as part of operational } \\
\text { interaction }\end{array}$ & \\
\hline & & for expedited criminal analysis & \multirow{7}{*}{$\begin{array}{l}\text { for analytical } \\
\text { research }\end{array}$} \\
\hline & & for thematic criminal analysis & \\
\hline & & for strategic criminal analysis & \\
\hline & & for use in GART-10 & \\
\hline & & for use in iBase databases & \\
\hline & & for use in other databases & \\
\hline & & other indicators & \\
\hline \multirow[t]{3}{*}{3} & \multirow[t]{3}{*}{$\begin{array}{l}\text { The degree of ability of a } \\
\text { network of information } \\
\text { sources to report a particular } \\
\text { object of immediate attention }\end{array}$} & $\begin{array}{l}\text { the number of sources of } \\
\text { information that have the } \\
\text { potential to retrieve information } \\
\text { about an object in an } \\
\text { operational focus }\end{array}$ & \\
\hline & & $\begin{array}{l}\text { the number of sources of } \\
\text { information, as well as } \\
\text { involved and to obtain } \\
\text { information object of } \\
\text { immediate attention }\end{array}$ & \\
\hline & & $\begin{array}{l}\text { sources of information, have } \\
\text { given notice of an object } \\
\text { prompt attention }\end{array}$ & \\
\hline \multirow[t]{3}{*}{4} & \multirow{3}{*}{$\begin{array}{l}\text { The degree of ability of a } \\
\text { network of information } \\
\text { sources to provide prompt } \\
\text { coverage of a particular area of } \\
\text { the terrain }\end{array}$} & $\begin{array}{l}\text { the number of sources of } \\
\text { information located in a } \\
\text { particular area }\end{array}$ & \\
\hline & & $\begin{array}{l}\text { the amount of reliable } \\
\text { information obtained from } \\
\text { sources of information in a } \\
\text { particular area }\end{array}$ & \\
\hline & & $\begin{array}{l}\text { (Normative) amount of } \\
\text { information required to } \\
\text { provide prompt coverage of a } \\
\text { particular area of land }\end{array}$ & \\
\hline \multirow[t]{3}{*}{5} & \multirow[t]{3}{*}{$\begin{array}{l}\text { The degree of conformity of } \\
\text { information properties to the } \\
\text { needs of the operational unit } \\
\text { for the effective fulfillment of } \\
\text { the tasks set by the legislation } \\
\text { of Ukraine }\end{array}$} & topicality & $\begin{array}{l}\text { degree of } \\
\text { correspondenc } \\
\text { e of } \\
\text { information of } \\
\text { the current } \\
\text { moment of } \\
\text { time }\end{array}$ \\
\hline & & adequacy & $\begin{array}{l}\text { compliance } \\
\text { level created } \\
\text { using image } \\
\text { data actually } \\
\text { the first } \\
\text { object, } \\
\text { process, } \\
\text { phenomenon. }\end{array}$ \\
\hline & & certainty & property to \\
\hline
\end{tabular}




\begin{tabular}{|c|c|c|c|}
\hline $\mathbf{S} / \mathbf{n}$ & $\begin{array}{c}\text { Name } \\
\text { complex indicator }\end{array}$ & Constituent elements & Note \\
\hline & & & $\begin{array}{l}\text { display really } \\
\text { existing } \\
\text { objects with } \\
\text { the required } \\
\text { precision. }\end{array}$ \\
\hline & & timeliness & $\begin{array}{l}\text { receiving } \\
\text { information } \\
\text { within the } \\
\text { time when it } \\
\text { is fit for } \\
\text { decision }\end{array}$ \\
\hline & & completeness & $\begin{array}{l}\text { characterizes } \\
\text { the quality of } \\
\text { information } \\
\text { and } \\
\text { determines the } \\
\text { adequacy of } \\
\text { data to make } \\
\text { decisions or to } \\
\text { generate new } \\
\text { data based on } \\
\text { available data } \\
\end{array}$ \\
\hline & & value & $\begin{array}{l}\text { a property of } \\
\text { information } \\
\text { that } \\
\text { determines the } \\
\text { degree of } \\
\text { achievement } \\
\text { of a goal by } \\
\text { the } \\
\text { information } \\
\text { obtained }\end{array}$ \\
\hline & & accessibility & $\begin{array}{l}\text { the extent to } \\
\text { which one or } \\
\text { other } \\
\text { information } \\
\text { can be } \\
\text { obtained }\end{array}$ \\
\hline & & objectivity & \multirow[b]{2}{*}{$\begin{array}{l}\text { Objectively } \\
\text { the assumed } \\
\text { that } \\
\text { information in } \\
\text { a second meth } \\
\text { od of } \\
\text { obtaining are } \\
\text { less subjective } \\
\text { element }\end{array}$} \\
\hline & & subjectivity & \\
\hline & & adequacy & $\begin{array}{l}\text { a property that } \\
\text { determines the } \\
\text { degree of } \\
\text { satisfaction, } \\
\text { suitability }\end{array}$ \\
\hline
\end{tabular}




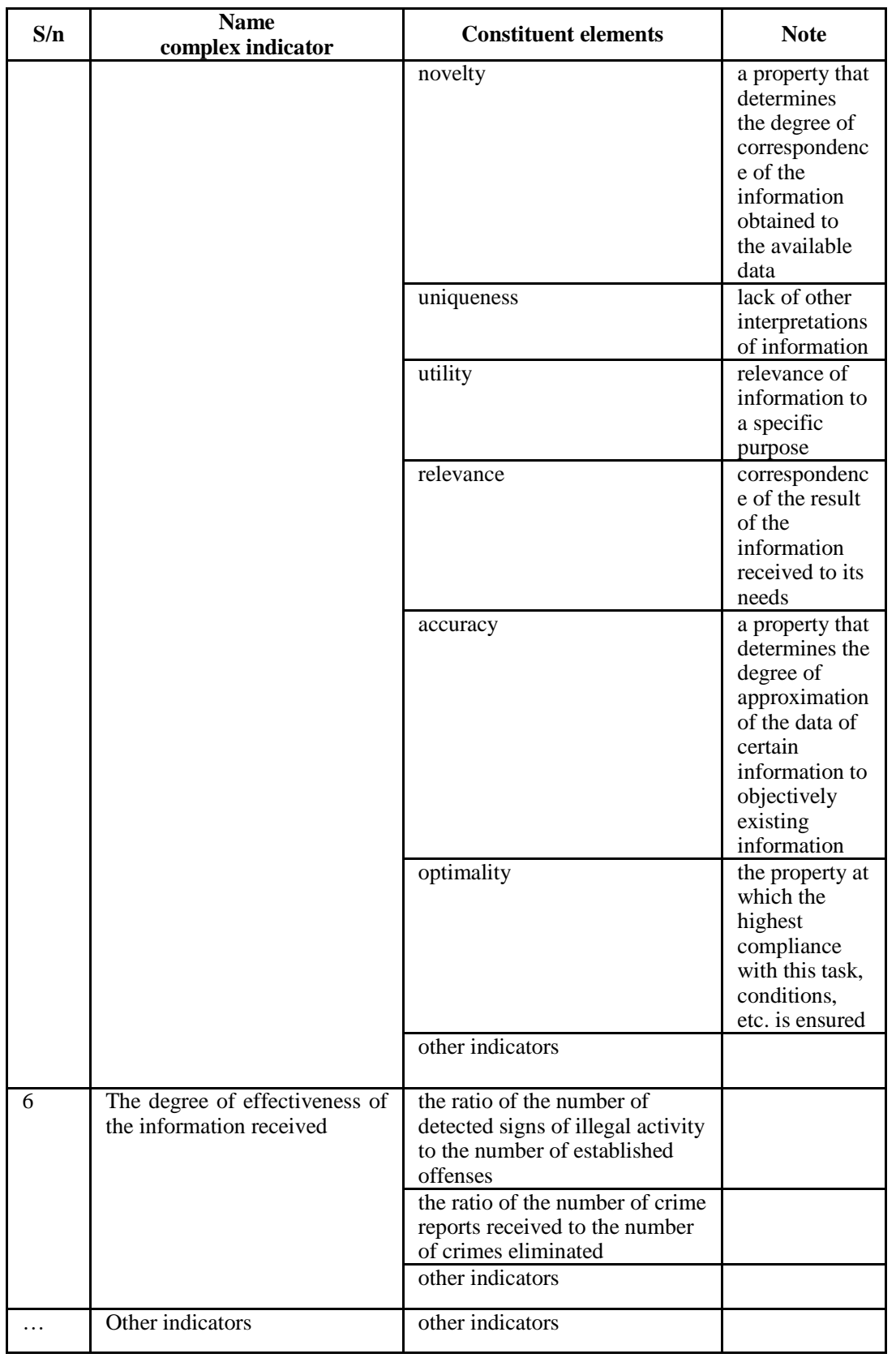




\begin{tabular}{|c|c|c|c|}
\hline $\mathbf{S} / \mathbf{n}$ & $\begin{array}{c}\text { Name } \\
\text { complex indicator }\end{array}$ & Constituent elements & Note \\
\hline \multicolumn{4}{|c|}{$\begin{array}{l}\text { II. Performance assessment of the implementation of measures analytical research aimed at } \\
\text { developing (development) analytical products, required to perform tasks operating unit }\end{array}$} \\
\hline \multirow[t]{7}{*}{1} & \multirow{7}{*}{$\begin{array}{l}\text { The degree of effectiveness of } \\
\text { the implementation of } \\
\text { analytical products in the } \\
\text { operational and operational } \\
\text { activities of the operational } \\
\text { unit }\end{array}$} & $\begin{array}{l}\text { the number of analytical } \\
\text { products that make the best } \\
\text { management decision }\end{array}$ & \\
\hline & & $\begin{array}{l}\text { number of analytical products } \\
\text { that contributed to the rational } \\
\text { distribution of forces and } \\
\text { resources of the operational } \\
\text { unit to accomplish tasks }\end{array}$ & \\
\hline & & $\begin{array}{l}\text { the number of analytical } \\
\text { products that produce a high } \\
\text { result of the use of forces and } \\
\text { means of the operational unit }\end{array}$ & \\
\hline & & $\begin{array}{l}\text { number of analytical products } \\
\text { that were used as evidence of } \\
\text { the involved east and } \\
\text { individuals to commit crimes }\end{array}$ & \\
\hline & & $\begin{array}{l}\text { number of analytical products, } \\
\text { in which could prevent the } \\
\text { commission of the offense }\end{array}$ & \\
\hline & & $\begin{array}{l}\text { the number of analytical } \\
\text { products that have been used to } \\
\text { stop the crime }\end{array}$ & \\
\hline & & other indicators & \\
\hline \multirow[t]{4}{*}{2} & \multirow{4}{*}{$\begin{array}{l}\text { The degree of effectiveness of } \\
\text { the implementation } \\
\text { of analytical products within } \\
\text { the framework of operational } \\
\text { interaction }\end{array}$} & $\begin{array}{l}\text { the number of analytical } \\
\text { products that have formed an } \\
\text { effective common crime- } \\
\text { fighting strategy }\end{array}$ & \\
\hline & & $\begin{array}{l}\text { the number of analytical } \\
\text { products used to expose and } \\
\text { eliminate an organized crime } \\
\text { group }\end{array}$ & \\
\hline & & $\begin{array}{l}\text { the number of analytical } \\
\text { products by which the cross- } \\
\text { border crime channel was } \\
\text { discovered and liquidated }\end{array}$ & \\
\hline & & other indicators & \\
\hline \multirow[t]{8}{*}{3} & \multirow{8}{*}{$\begin{array}{l}\text { The degree of quality of } \\
\text { processing of analytical } \\
\text { research products }\end{array}$} & $\begin{array}{l}\text { the total volume of the } \\
\text { analytical product }\end{array}$ & \\
\hline & & volume of specific material & \\
\hline & & volume of reliable data & \\
\hline & & volume of accurate data & \\
\hline & & $\begin{array}{l}\text { the volume of valid conclusions } \\
\text { and suggestions }\end{array}$ & \\
\hline & & $\begin{array}{l}\text { timeliness of analytical } \\
\text { research }\end{array}$ & \\
\hline & & topicality & \\
\hline & & other indicators & \\
\hline 4 & $\begin{array}{l}\text { The degree of quality } \\
\text { of monitoring research that he }\end{array}$ & $\begin{array}{l}\text { number of quality analytical } \\
\text { products, developed on the }\end{array}$ & \\
\hline
\end{tabular}




\begin{tabular}{|c|c|c|c|}
\hline $\mathbf{S} / \mathbf{n}$ & $\begin{array}{c}\text { Name } \\
\text { complex indicator }\end{array}$ & Constituent elements & Note \\
\hline & $\begin{array}{l}\text { ealizuye appear on the basis of } \\
\text { information, obtained from the } \\
\text { «traditional» and } \\
\text { «nontraditional» sources }\end{array}$ & $\begin{array}{l}\text { basis of collecting information } \\
\text { from «traditional» and } \\
\text { «nontraditional» sources to } \\
\text { meet the needs of the } \\
\text { operational unit }\end{array}$ & \\
\hline & & $\begin{array}{l}\text { the effectiveness of the } \\
\text { application of analytical } \\
\text { methods of researching the } \\
\text { information obtained from } \\
\text { «traditional» and «non- } \\
\text { traditional» sources for the } \\
\text { information support of } \\
\text { operational and operational } \\
\text { activities of the operational unit }\end{array}$ & \\
\hline & & $\begin{array}{l}\text { indicator of continuity of } \\
\text { monitoring research of } \\
\text { «traditional» and «non- } \\
\text { traditional»s sources to ensure } \\
\text { regular information support of } \\
\text { operational and operational } \\
\text { activities of the operational unit }\end{array}$ & \\
\hline & & other indicators & \\
\hline$\ldots$ & Other indicators & other indicators & \\
\hline \multicolumn{4}{|c|}{$\begin{array}{l}\text { III. Indicators of assessment of the status of the IAA organization in the operational unit of } \\
\text { the STS of Ukraine }\end{array}$} \\
\hline \multirow[t]{4}{*}{1} & \multirow{4}{*}{$\begin{array}{l}\text { Leader's ability to prioritize } \\
\text { IAA tasks to achieve effective } \\
\text { operational and operational } \\
\text { outcomes of the operational } \\
\text { unit }\end{array}$} & $\begin{array}{l}\text { the ability of the manager to } \\
\text { determine the needs of the } \\
\text { operational unit in IAA }\end{array}$ & \\
\hline & & $\begin{array}{l}\text { the ability of the head defined } \\
\text { atm performers analytical } \\
\text { research priorities according to } \\
\text { the objectives IAA }\end{array}$ & \\
\hline & & $\begin{array}{l}\text { the ability of the manager to } \\
\text { set tasks with IAA in their } \\
\text { importance }\end{array}$ & \\
\hline & & other indicators & \\
\hline \multirow[t]{6}{*}{2} & \multirow{6}{*}{$\begin{array}{l}\text { Degree of ability of analysts of } \\
\text { operational unit to develop } \\
\text { qualitative analytical products }\end{array}$} & $\begin{array}{l}\text { time spent developing an } \\
\text { analytical product }\end{array}$ & \\
\hline & & $\begin{array}{l}\text { number of cases of receiving / } \\
\text { not receiving necessary } \\
\text { information for analytical } \\
\text { research }\end{array}$ & \\
\hline & & $\begin{array}{l}\text { stupas and Hb goal develop } \\
\text { analytical products }\end{array}$ & \\
\hline & & $\begin{array}{l}\text { the ability of data banks to } \\
\text { provide the necessary } \\
\text { information }\end{array}$ & \\
\hline & & $\begin{array}{l}\text { the ability of software to carry } \\
\text { out information research }\end{array}$ & \\
\hline & & the ability of the technical & is determined \\
\hline
\end{tabular}




\begin{tabular}{|c|c|c|c|}
\hline $\mathbf{S} / \mathbf{n}$ & $\begin{array}{c}\text { Name } \\
\text { complex indicator }\end{array}$ & Constituent elements & Note \\
\hline & & $\begin{array}{l}\text { means to receive and process } \\
\text { information }\end{array}$ & $\begin{array}{l}\text { by its } \\
\text { functionality } \\
\text { and usability }\end{array}$ \\
\hline 3 & $\begin{array}{l}\text { The degree of flexibility of the } \\
\text { IAA operational unit }\end{array}$ & $\begin{array}{l}\text { dependence on the time } \\
\text { required for processing the } \\
\text { information received, on time, } \\
\text { needed to rebuild IAA for } \\
\text { processing }\end{array}$ & \\
\hline 4 & $\begin{array}{l}\text { The degree of efficiency of } \\
\text { IAA }\end{array}$ & $\begin{array}{l}\text { the dependence of the time } \\
\text { required to process the } \\
\text { information received from the } \\
\text { available time to submit the } \\
\text { necessary information to make } \\
\text { a decision }\end{array}$ & \\
\hline \multirow[t]{2}{*}{5} & \multirow[t]{2}{*}{$\begin{array}{l}\text { The degree of concealment } \\
\text { IAA }\end{array}$} & $\begin{array}{l}\text { the total amount of information } \\
\text { that is extracted at a given time }\end{array}$ & \\
\hline & & $\begin{array}{l}\text { the amount of information } \\
\text { known to offenders at this point } \\
\text { in time }\end{array}$ & \\
\hline \multirow[t]{2}{*}{6} & \multirow[t]{2}{*}{$\begin{array}{l}\text { The degree of resistance of the } \\
\text { IAA }\end{array}$} & $\begin{array}{l}\text { the ratio of the time of absence } \\
\text { of receiving data of the } \\
\text { situation for a certain period to } \\
\text { the total time }\end{array}$ & \\
\hline & & $\begin{array}{l}\text { the ability to counteract the } \\
\text { conditions and factors that } \\
\text { influence the effectiveness of } \\
\text { IAA }\end{array}$ & \\
\hline \multirow[t]{4}{*}{7} & \multirow[t]{4}{*}{ The degree of readiness IAA } & $\begin{array}{l}\text { readiness of the network of } \\
\text { sources of information }\end{array}$ & \\
\hline & & $\begin{array}{l}\text { readiness of forces and means } \\
\text { of operational unit for } \\
\text { information processing }\end{array}$ & \\
\hline & & $\begin{array}{l}\text { the readiness of the } \\
\text { management of the operational } \\
\text { unit to organize the IAA }\end{array}$ & \\
\hline & & other indicators & \\
\hline & Other indicators & other indicators & \\
\hline
\end{tabular}

The set of indicators shown in Table 1 is a qualitative and quantitative characteristic of the IAA properties of the operational unit of the State Customs Service of Ukraine, which in combination allows to estimate the general state of the said activity. Therefore, the procedure for assessing the status of IAA is to determine the quality of execution of the processes of receipt (collection, extraction), processing of data of the situation, their organization in accordance with the needs of the operational unit of the STS of Ukraine. The quality of the IAA state is a set of properties that determine the ability to meet the necessary needs in accordance with the purpose. 
Quality Score is an indicator related to only one of the IAA properties, and a comprehensive Quality Score is relative to several of its properties ${ }^{16}$.

Therefore, for the overall assessment of the IAA status of the operational units of the STS of Ukraine, it is necessary to define an integral indicator that characterizes the ability of its constituent processes to fulfill the tasks and the ability to meet the needs at a high level.

To develop a methodology for assessing the status of IAA, it is necessary to define a system of rules that allow to obtain a complex assessment of the quality of implementation of the processes of the specified activity, adjusting them through management decisions and meeting the needs of operational and operational activities of the operational unit.

The methodology should include V. Gorodnov ${ }^{17}$ (Gorodnov, 2004b):

a description of the assessment situation in the light of the objective;

IAA processes to which the methodology is applied;

needs taking into account the requirements for the development of the methodology;

list of indicators with definition of scales of their measurement;

algorithm of actions for estimation of values of indicators;

a list of decisions made in accordance with the comprehensive assessment.

On the basis of the analysis of IAA of operational units of the State traffic police of Ukraine, its purpose, tasks and a significant system of rules, a method of assessment of the state of IAA of the operational unit of the State traffic police of Ukraine in the following stages was developed according to G. Azgaldov and, E. Rajhman ${ }^{18}$ (Azgaldov \& Rajhman, 1973a); G. Azgaldov ${ }^{19}$ (Azgaldov, 1982):

1. Description of the assessment situation. At this stage, a description of the IAA is met to meet the needs of the operating unit for the period (eg, month, year).

${ }^{16}$ Busel V. T. (2009) Velikij tlumachnij slovnik suchasnoyi ukrayinskoyi movi [A great explanatory dictionary of modern Ukrainian (with additions, supplements and CDs)]. Kiev : Irpin: VTF «Perun», 1736 p. (in Ukrainian)

17 Gorodnov V.P. (2004) Metodika ocenki effektivnosti variantov obespecheniya funkcionirovaniya sistemy raznorodnyh mnogoparametricheskih obektov razlichnoj vazhnosti [Methodology for assessing the effectiveness of operational options systems of heterogeneous multi-parameter objects of various importance]. Naukove vidannya Sistemi obrobki informaciyi. Harkiv : NANGU, no. 2, pp. 159-163 (in Russian)

${ }^{18}$ Azgaldov G. G., Rajhman E. P. (1973) O kvalimetrii [About qualimetry]. M. : Izd-vo standartov, 172 p. (in Russian)

${ }^{19}$ Azgaldov G. G. (1982) Teoriya i praktika ocenki kachestva tovarov. Osnovy kvalimetrii [Theory and practice of assessing the quality of goods. Fundamentals of qualimetry]. M., Ekonomika, 256 p. (in Russian) 
2. Determination of conditions affecting IAA.

3. Substantiation of requirements for IAAs and their implementation processes.

4. Deciding on the assessment of the status of IAA. Here, decisions are made to meet the conditions for quantitative assessment of the quality of the activity. A set of such solutions determines the composition of indicators and how they are used.

5. Selection and justification of the list of properties and indicators IAA needed to assess its status. Due to the fact that the processes operating unit IAA is characterized by a large number of properties as and form a quality activity, vital question of choice is her cumulative spine properties as a more interesting one's person, which assesses the state of IAA. To evaluate the IAA status of the operational unit, only those properties that meet its needs are required. Properties are divided into simple ones, which are grouped and measured by a complex metric, and complex ones. Complex metrics are combined into more complex groups at the time the overall comprehensive metric is obtained. This metric structure is based on the IAA property tree according to G. Azgaldov and, E. Rajhman (Azgaldov \& Rajhman, 1973b).

Some indicators are normative, for example, the amount of time it takes th for analytical research within the operational business. Indicators that characterize the qualitative properties of IAAs are calculated using peer review methods. However, the value of each indicator of the quantitative and qualitative characteristics of the properties of a particular process may vary over a different period of time. This is due to the influence of different conditions (factors affecting the status of IAA; threats to border security, etc.), so for more accurate calculation their impact factors should be taken into account.

6. Determination of quantitative value of indicators and the order of their calculation.

Quantitative and qualitative indicators have the inherent dimension and peculiarities of calculations.

7. Determination of the weight of the coefficients of indicators. At this stage, the coefficient of weight of each of the IAA indicators and the coefficients of the weight of the effect of conditions on the IAA are determined, the coefficient of the tasks solved by the operational unit with the help of the IAA.

8. Building a graph of the dependence of IAA indicators according to the calculated indicators and the weight of the influence of the coefficients plot a dependence.

9. Formation of an integral indicator of the IAA status of the operational unit. The procedure for forming an integral indicator of the IAA status 
assessment of the operational units of the STS of Ukraine is presented in in Figure 1.

10. Carrying out calculations of the IAA status of the operational unit based on the integrated integral index.

11. Checking the reliability of the developed methodology.

This stage is characterized by determining the compliance of the IAA operational unit to meet the needs of the operational unit in full, at a sufficiently high level, for a specified time and under the influence of various factors.

12. Determination of conformity of the calculated value of the state of IAA to its level and management decision making.

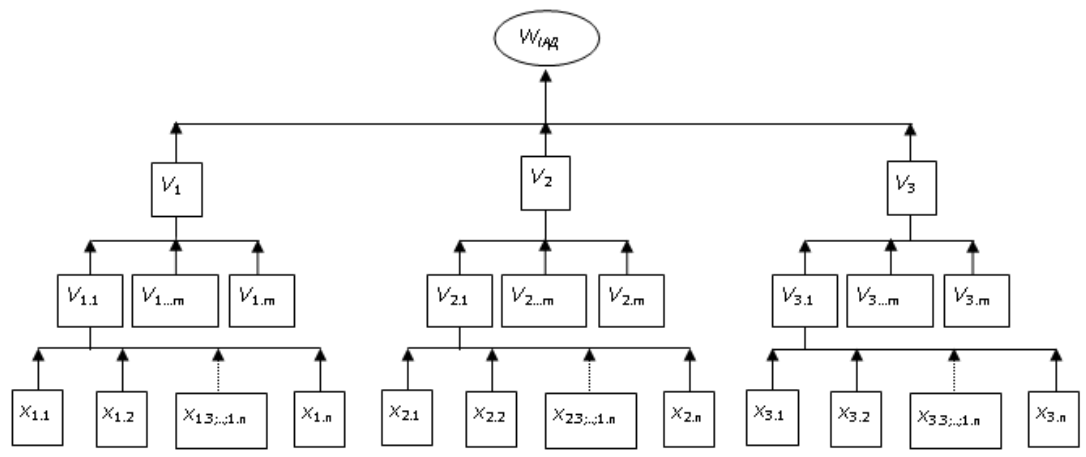

Note:

$W$ is an integral indicator of estimation of IAA status;

$V_{1}$ - the overall complex indicator of the properties of the process of collecting (extracting) information;

$V_{2}$ - the overall complex indicator of the properties of the information processing process;

$V_{3}$ - the overall complex indicator of the properties of the process of organization of IAA;

$V_{1.1}$ - a complex indicator with / $\mathrm{n} 1$ (see table. 1) the process of gathering (extracting) information;

$x$ is an indicator of the individual IAA property;

$m$ is the number of complex indicators of the properties of a single IAA process;

$n$ is the number of metrics in a complex metric.

Fig. 1. Formation of an integral indicator of assessment of the state of information and analytical activity of operational units of the State Border Guard Service of Ukraine 
The scientific approach proposed by Harrington E. Harrington is used to determine the level to which the IAA status in operational units corresponds E. Harrington $^{20}$ (Harrington, 1965). The level determination is set in accordance with the value of the integral indicator of the IAA state at the interval from zero to one. If the value of the complex index is the same assessment of IAA units, the current state of IAA is the best and corresponds (meets) needs, that it has put forward. Table 2 presents the levels of compliance of the integral indicator of the IAA status levels.

Table 2

Determination of the level of information and analytical activity of the operational units of the State Border Guard Service of Ukraine

\begin{tabular}{|c|c|}
\hline Level & $\begin{array}{c}\text { The numerical value of the integral indicator } \\
\text { of the IAA state }\end{array}$ \\
\hline High & $0.81-1.00$ \\
Sufficient & $0.64-0.80$ \\
Low & $0.43-0.63$ \\
Unsatisfactory & $0.00-0.42$ \\
\hline
\end{tabular}

Based on the determined level of the IAA, the head of the operational unit makes decisions on adjusting, where necessary, the activities of the IAA in the subordinate unit.

Algorithm assessment methodology condition IAA operating unit is logically consistent structure precisely defined actions, combined with payments for performance, presented in Table 1, to achieve the goal of modeling. One example of such an algorithm would be the sequence of forming an integral index for estimating the IAA state, which is presented in Figure 1.

For convenience and to reduce the time of calculations, the evaluation of the IAA status of the operational unit is carried out using special software.

\section{SUMMARY}

The scientific article investigates the processes of collecting (retrieving) information on the operational and criminogenic situation on the State border of Ukraine; analysis of received and available data; organization of IAA in the operational-search units of the State border service of Ukraine. The groups of factors influencing the IAA of the operational-search units of the State border service of Ukraine are specified.

${ }^{20}$ Harrington E. C. (1965) The Desirability Function. Industrial Quality Control. April, pp. 494-498. (in English) 
On the basis of the analysis of IAA of the operational-search units of the State border service of Ukraine, the nature of the influence of various factors and scientific researches of the said activity, a group of indicators was formed, by which it became possible to carry out qualitative and quantitative assessment of the properties of the IAA of the division-division. The procedure of forming an integral indicator of estimation of the state of IAA is proposed.

Further research allowed to develop a methodology for assessing the state of IAA of the operative-search unit of the State border guard service of Ukraine in a series of stages, which are presented in a logical sequence.

It is suggested to use the Harrington function scale to determine the level to which the IAA in the operational-search unit corresponds.

The developed methodology is of practical importance, which consists in the ability of heads of operational and search units of the State border security of Ukraine to assess the state of IAA of the subordinate unit, identify the mistakes made in the process of organizing this activity, identify priority areas of work and formulate the necessary areas for work .

The prospect of further scientific research is the determination of more expedient methods of finding quantitative values of indicators of the IAA status assessment of the operational unit of the State border security of Ukraine.

\section{REFERENCES}

1. Pro derzhavnij kordon Ukrayini (1992) [About the State Border of Ukraine] : Zakon Ukrayini vid 04.11.1991 r. № 1777-XII / Vidomosti Verhovnoyi Radi Ukrayini. № 2. St. 5 (z nastupnimi zminami ta dopovnennyami). (in Ukrainian)

2. Pro operativno-rozshukovu diyalnist (1992) [About the operativesearch activity] : zakon Ukrayini vid 18.02.1992 r. № 2135-XII. Data onovlennya: 28.08.2019. URL: http://zakonl.rada.gov.ua/laws/ show/213512/page (data zvernennya: 12.09.2019). (in Ukrainian)

3. Lyashuk R. M., Farion O. B. (2019) Informacijno-analitichna diyalnist operativno-rozshukovih pidrozdiliv Derzhavnoyi prikordonnoyi sluzhbi Ukrayini [Information and analytical activity of the operational and search units of the State Border Guard Service of Ukraine]. Zb. nauk. pr. Hmelnickij : NA DPSU, no. 30, pp. 62-75. (in Ukrainian)

4. Rezultati operativno-sluzhdbovoyi diyalnosti Derzhavnoyi prikordonnoyi sluzhbi Ukrayini (2019) [Results of the operational and service activities of the State Border Guard Service of Ukraine]. Data onovlennya: 10.12.2019. URL:https://dpsu.gov.ua/ua/photo-infografikarezultati-operativno-sluzhbovoi-diyalnosti-za-2019-rik/(data zvernennya: 12.12.2019). (in Ukrainian) 
5. Pro zatverdzhennya Polozhennya pro operativno-rozshukovij viddil organu ohoroni derzhavnogo kordonu (2015) [On approval of the Regulation on the Operational and Investigative Division of the State Border Protection Body] : nakaz Ministerstva vnutrishnih sprav Ukrayini vid 02.02.2015 № 118 URL: https://zakon.rada.gov.ua/laws/show/z0187-15 (data zvernennya: 12.09.2019). (in Ukrainian)

6. Vojtovich A. I., Farion O. B. (2010) Poryadok viznachennya prioritetu protipravnih situacij, sho vinikayut na richkovij dilyanci derzhavnogo kordonu [The procedure for determining the priority of unlawful situations occurring at the river section of the state border]. $Z b$. nauk. pr. : trudi akademiyi. Kiev : NAOU, no. 6(99), pp. 98-102. (in Ukrainian)

7. Tsygikal P. O., Farion O. B. (2017) Model rozpiznavannya zlochiniv operativno-rozshukovim viddilom Derzhavnoyi prikordonnoyi sluzhbi Ukrayini dlya svoyechasnogo yih poperedzhennya, viyavlennya i pripinennya [Model of crime detection by the Operational Investigation Department of the State Border Guard Service of Ukraine for their timely prevention, detection and termination]. Zb. nauk. pr. Hmelnickij : NA DPSU, no. 1(71), pp. 238-255. (in Ukrainian)

8. Farion O. B. (2018) Okremi prijomi i sposobi monitoringu prihovanih resursiv Internetu, nakopichennya informaciyi ta doslidzhennya oznak protipravnoyi diyalnosti iz zastosuvannyam kriminalnogo analizu [Separate techniques and methods for monitoring hidden Internet resources, accumulating information and investigating signs of criminal activity using criminal analysis]. Zb. nauk. pr. ser. Hmelnickij : NA DPSU, no. 29, pp. 119-130. (in Ukrainian)

9. Farion O. B. (2013) Instrumentarij viznachennya tipu zagroz prikordonnij bezpeci $\mathrm{v}$ procesi provedennya strategichnogo kriminalnogo analizu operativno-rozshukovim pidrozdilom regionalnogo upravlinnya Derzhavnoyi prikordonnoyi sluzhbi Ukrayini [Toolkit for determining the type of border security threats in the process of strategic criminal analysis operational-search unit of the regional department of the State Border Service of Ukraine]. Zb. nauk. pr. ser. Hmelnickij : $N A D P S U$, no. 2(60), pp. 212-218. (in Ukrainian)

10. Cigikal P. O., Farion O. B. (2017) Model rozpiznavannya zlochiniv operativno-rozshukovim viddilom Derzhavnoyi prikordonnoyi sluzhbi Ukrayini dlya svoyechasnogo yih poperedzhennya, viyavlennya i pripinennya [Model of crime detection by the Operational Investigation Department of the State Border Guard Service of Ukraine for their timely prevention, detection and termination]. Zb. nauk. pr. ser. Hmelnickij : NA $D P S U$, no. 1(71), pp. 238-255. (in Ukrainian) 
11. Gorodnov V. P. (2004) Metodika ocenki effektivnosti variantov obespecheniya funkcionirovaniya sistemy raznorodnyh mnogoparametricheskih obektov razlichnoj vazhnosti [Methodology for assessing the effectiveness of operational options systems of heterogeneous multiparameter objects of various importance]. Naukove vidannya Sistemi obrobki informaciyi. Harkiv : NANGU, no. 2, pp. 159-163 (in Russian)

12. Vojtovich A. I., Farion O. B. (2010) Poryadok viznachennya prioritetu protipravnih situacij, sho vinikayut na richkovij dilyanci derzhavnogo kordonu [The procedure for determining the priority of unlawful situations occurring at the river section of the state border]. $Z b$. nauk. pr. : trudi akademiyi. Kiev : NAOU, no. 6 (99), pp. 98-102. (in Ukrainian)

13. Cigikal P. O. (2017) Metodika formuvannya sistemi informacijnogo zabezpechennya operativno-rozshukovoyi diyalnosti Derzhavnoyi prikordonnoyi sluzhbi Ukrayini v umovah teritorialnoyi oboroni [Methods of Formation of Information Support System for Operational and Investigative Activity of the State Border Guard Service of Ukraine in Territorial Defense]. Shokvartalnij naukovij zhurnal Chest i zakon. Harkiv : NANGU, no. 4 (63). 104 p. (in Ukrainian)

14. Farion O. B. (2013) Instrumentarij viznachennya tipu zagroz prikordonnij bezpeci $\mathrm{v}$ procesi provedennya strategichnogo kriminalnogo analizu operativno-rozshukovim pidrozdilom regionalnogo upravlinnya Derzhavnoyi prikordonnoyi sluzhbi Ukrayini [Toolkit for determining the type of border security threats in the process of strategic criminal analysis operational-search unit of the regional department of the State Border Service of Ukraine]. Zb. nauk. pr. Hmelnickij : NA DPSU, no. 2(60), pp. 212-218. (in Ukrainian)

15. Cigikal P. O. (2017) Obgruntuvannya sistemi chastkovih pokaznikiv formuvannya sistemi informacijnogo zabezpechennya operativnorozshukovoyi diyalnosti Derzhavnoyi prikordonnoyi sluzhbi Ukrayini v umovah teritorialnoyi oboroni [Substantiation of the system of partial indicators of the formation of the system of information support of the operational and search activity of the State Border Guard Service of Ukraine in the conditions of territorial defense]. Zb. nauk. pr. K. : CNDI ZSU, no. 3(81), pp. 222-230. (in Ukrainian)

16. Busel V.T. (2009) Velikij tlumachnij slovnik suchasnoyi ukrayinskoyi movi [A great explanatory dictionary of modern Ukrainian (with additions, supplements and CDs)]. Kiev : Irpin: VTF «Perun», 1736 p. (in Ukrainian)

17. Gorodnov V. P. (2004) Metodika ocenki effektivnosti variantov obespecheniya funkcionirovaniya sistemy raznorodnyh mnogoparametricheskih obektov razlichnoj vazhnosti [Methodology for 
assessing the effectiveness of operational options systems of heterogeneous multi-parameter objects of various importance]. Naukove vidannya Sistemi obrobki informaciyi. Harkiv : NANGU, no. 2, pp. 159-163 (in Russian)

18. Azgaldov G. G., Rajhman E. P. (1973) O kvalimetrii [About qualimetry]. $M$. : Izd-vo standartov, 172 p. (in Russian)

19. Azgaldov G. G. (1982) Teoriya i praktika ocenki kachestva tovarov. Osnovy kvalimetrii [Theory and practice of assessing the quality of goods. Fundamentals of qualimetry]. M., Ekonomika, 256 p. (in Russian)

20. Harrington E. C. (1965) The Desirability Function. Industrial Quality Control. April, pp. 494-498. (in English)

\section{Information about the author: \\ Oleh Farion,}

candidate of military sciences, associate professor, student of doctoral studies, Bohdan Khmelnytskyi National Academy of the State Border Guard Service of Ukraine 46 Shevchenka str., Khmelnitskyi, 29007, Ukraine ORCID ID: orcid.org/0000-0001-6751-0468 


\section{STUDY OF DETECTION AND TRACKING ALGORITHMS OF MOVING OBJECTS IN VIDEO SEQUENCES FROM VIDEO SURVEILLANCE CAMERAS}

\section{Anatolii Babaryka}

\section{INTRODUCTION}

The wide availability of video surveillance systems has led to a situation where we have the opportunity to place a sufficiently large number of surveillance cameras on controlled objects, but at the same time there is a problem of monitoring the situation from them. Video surveillance operators are physically unable to simultaneously monitor information from 10-15 or even more video channels. That is why, a logical step in the development of video surveillance systems is the introduction of video analytics functions.

One of the detectors that are used in modern intelligent video surveillance systems is the conditional line crossing detector. The logic of this detector is that the operator in the software interface builds a conditional line, at the intersection of which certain objects (persons, vehicles or any moving objects) there is a visual (and / or sound) alarm.

Therefore, the introduction of this type of detectors in video surveillance systems, which are deployed at facilities with perimeter security, will effectively monitor the situation in the sectors of video surveillance cameras on a certain number of video channels at the same time.

Survey of algorithms for detection and tracking of objects in video sequences was conducted in the works of a wide range of scientists, such as Boris Babenko, P. Viola and M. J. Jones, Zhengxia Zou, Zhenwei Shi, Yuhong Guo, Redmon J., Liu W., Anguelov D., Erhan D., Szegedy C., S. Reed, C.-Y. Fu, A. C. Berg, et al. In the works of these authors, considerable attention is paid to the analysis, development and development of these algorithms.

For the purpose of further practical implementation of the problem of detecting the intersection of the conditional line by moving objects, it is advisable to analyze the existing methods of detecting and tracking moving objects.

\section{Classification of maintenance algorithms}

In modern video surveillance systems with functions of automated processing of video information, one of the important tasks is the detection 
of moving objects, construction of trajectories of their movement and analysis. Difficulties in the implementation of the task of tracking detected objects due to changes in the environment, movement of the object and changing its shape during movement, interference, etc.

In article ${ }^{1}$, based on the analysis of the current state of functioning of the departmental surveillance subsystems included in the integrated informationtelecommunication system "Gart» of the State border guard service of Ukraine, was identified a list of tasks that can be performed by the specified subsystem with the introduction of intelligent video processing (video analytics).

One of such tasks of intelligent video surveillance systems is detection of video sequences of crossing objects of a conditional line. To implement the above task, it is necessary to solve the following particular problems, namely: identification of objects, their localization, tracking from frame to frame and fixing the moment of intersection of a group of pixels, to connect the «object of interest» with pixels that belong to the «conditional line».

Based on certain tasks, the actual task is to conduct a study of modern algorithms for detection, tracking and analysis of the features of the trajectory of moving objects in the sectors of surveillance cameras.

Let us define a list of restrictions and assumptions that characterize the features of the functioning of the mentioned systems in video surveillance systems installed at checkpoints across the state border and on the territory of military camps, where the «objects of interest» are vehicles and people; the speed of detection of a moving object is not critical (is a few seconds); the load on the hardware must be minimized; the algorithm must be guaranteed to detect moving objects.

Taking into account certain limitations and assumptions, we will analyze the existing algorithms for detecting, tracking and analyzing the features of the trajectory of moving objects. Under the concept of object detection we will understand the process of determining the location of the object in the frame.

Object detection detectors are usually more computationally intensive and, accordingly, have lower performance than object tracking algorithms.

Therefore, for optimal use of resources of electronic computer technology are used hybrid approaches, which are built on the concept of

1 Katerynchuk I., Babaryka A. (2018) Doslidzhennya algoritmiv viyavlennya ta suprovodzhennya ruhomih ob'yektiv u videoposlidovnostyah z kamer videosposterezhennya. [Analysis of the Technologies of the Functioning Specific Video Surveillance Systems and the Definition of their Directions of Improvement]. Collection of scientific works of the National Academy of the State Border Guard Service of Ukraine. Series: Military and Technical Science. no. 3(77). pp. 246-259 (in Ukrainian). 
combining algorithms of detection and tracking of objects in one algorithm. The work of such algorithms is divided into two stages:

1. The detection stage, during which the algorithm for detecting new objects and objects that were «lost» by the tracking algorithm during the other stage. For each detected object, the object tracker is added or updated with new bounding box coordinates. This stage lasts a certain number of frames, and each time repeats.

2. The tracking phase begins when the detection phase stops.

At this point, algorithm tracks the object as it moves in the frame using the created object tracker. This procedure continues for a certain number of frames until the discovery phase begins again, after which the follow-up phase begins again.

To support objects in the video, it is necessary to solve the problem of detection of such objects. The solution of this problem is assigned to the object designers. Historically, the process of development of algo-rhythms of object detection can be divided into two periods:

- the period of identification of objects by traditional methods - until 2014;

- the period of object detection based on deep learning methods after 2014 ${ }^{2}$. (Fig. 1)

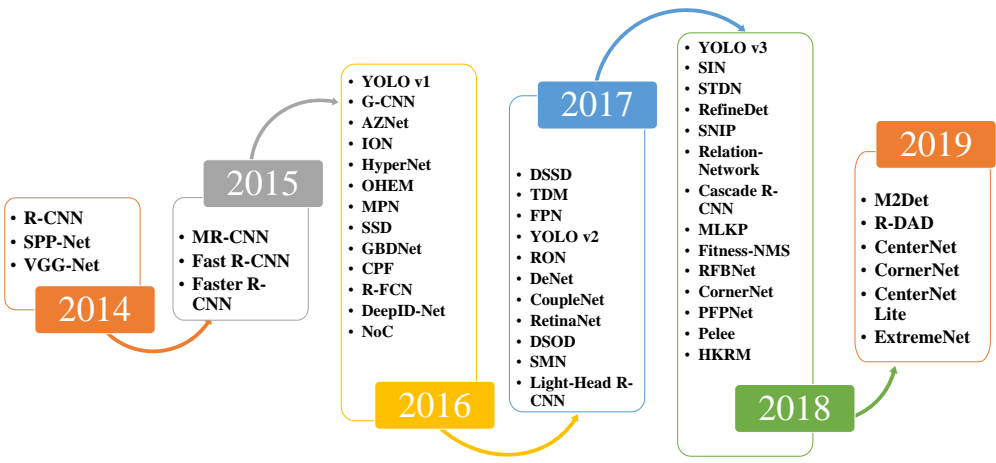

Fig. 1. Timeline of development of object detection algorithms from 2014 to 2019

${ }^{2}$ Zou Z., Shi Z., Guo Y., \& Ye J. (2019) Object Detection in 20 Years: A Survey. ArXiv, abs/1905.05055. (in English) 
Until 2014, most research efforts have focused on identifying a specific category of objects, such as pedestrians, faces, vehicles, etc., using precreated sets of relevant features.

The easiest way to solve the object detection task is to reduce it to a classification task. To identify an object, you must take a specific classifier and apply it to areas of the image. To play such areas use the method of «sliding window».

So, in 2001, P. Viola and M. Jones proposed a method that allowed realtime detection of faces in images ${ }^{3,4}$. The Viola-Jones detector uses a sliding window method that allows scaling and sliding window positions to detect if there are pixel sets in any window that match the face image. Haar cascades are used as a classifier (Fig. 2).
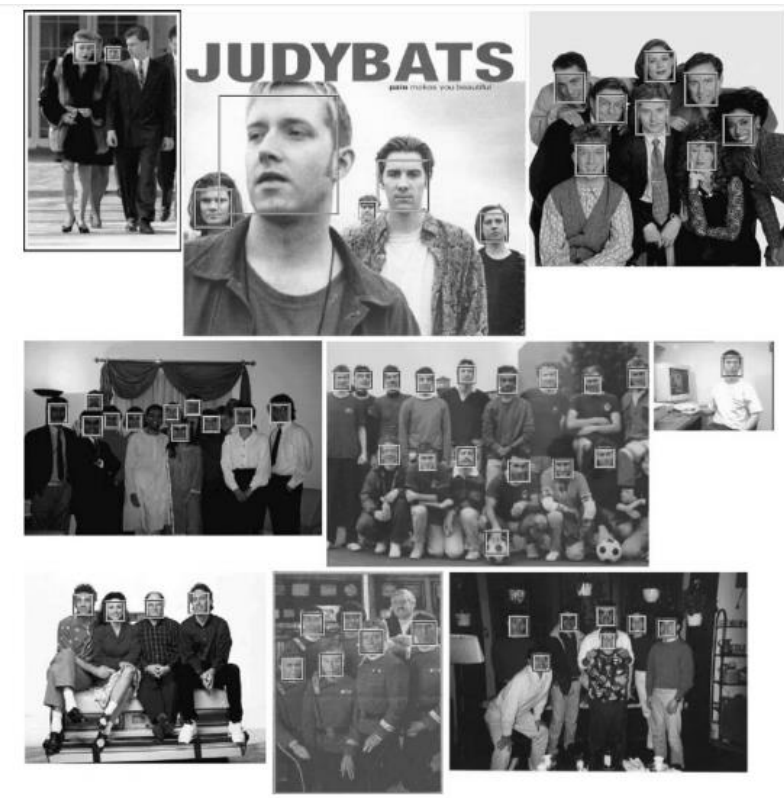

Fig. 2. The result of the Viola-Jones algorithm ${ }^{4}$

${ }^{3}$ Viola P. A., \& Jones M. J. (2001) Rapid object detection using a boosted cascade of simple features. Proceedings of the 2001 IEEE Computer Society Conference on Computer Vision and Pattern Recognition. CVPR 2001, 1, I-I. DOI: 10.1109/CVPR.2001.990517. (in English)

${ }^{4}$ Viola P. A., Jones M. J. (2001) Robust real-time face detection. Proceedings Eighth IEEE International Conference on Computer Vision. ICCV 2001, no. 2, pp.747-747. DOI: 10.1023/B:VISI.0000013087.49260.fb. (in English) 
In 2005, N. Dalal and B. Triggs proposed a method called the HOG (Histogram of Oriented Gradients) ${ }^{5}$. The HOG detector scales the input image several times, keeping the size of the detection window unchanged. The basic idea of the algorithm is the assumption that the appearance and shape of the object in the image can be described by the intensity gradient distribution function.

In 2008 Felzenszwalb, P.F., McAllester, D.A., \& Ramanan, D proposed a method called the DPM ${ }^{6}$.

In 2012, at ImageNET, a surefire win is the algorithm based on the use of convolutional neural networks (AlexNet) and this becomes a turning point in the development of neural networks.

State of the art object detection algorithms can be divided into the following categories:

- algorithms are based on «two-stage detection»;

- algorithms are based on «one-stage detection»;

- algorithms are based on point-based detection;

- algorithms are based on other author's approaches.

In two-stage detection, the algorithm in the first stage selects the regions in which the objects of interest are likely to be located, and in the second stage the classification problem is solved. R-CNN was the first twostagemethod. After it, appeared such detectors as Fast-RCNN, Faster R-CNN, Mask R-CNN and others. Two-stage architectures have high accuracy, but for practical application, frame processing speed very important.

One-stage algorithms solve the detection problem as a regression task. Such detectors are a single convolutional neural network, which outputs localized regions of objects of interest, their classification and the correction of the bounding box. You Only Look Once $-\mathrm{YOLO}^{7}$ was the first one-stage method (Fig. 3).

${ }^{5}$ Dalal N., Triggs B. (2005) Histograms of oriented gradients for human detection. 2005 IEEE Computer Society Conference on Computer Vision and Pattern Recognition (CVPR'05), 1, 886-893 vol. 1. (in English)

${ }^{6}$ Felzenszwalb P. F., McAllester D. A., Ramanan D. (2008) A discriminatively trained, multiscale, deformable part model. 2008 IEEE Conference on Computer Vision and Pattern Recognition, pp. 1-8. DOI: 10.1109/CVPR.2008.4587597. (in English)

${ }_{7}$ Redmon J., Divvala S.K., Girshick R.B., Farhadi A. (2015) You Only Look Once: Unified, Real-Time Object Detection. 2016 IEEE Conference on Computer Vision and Pattern Recognition (CVPR), pp. 779-788. DOI: 10.1109/CVPR.2016.91. (in English) 


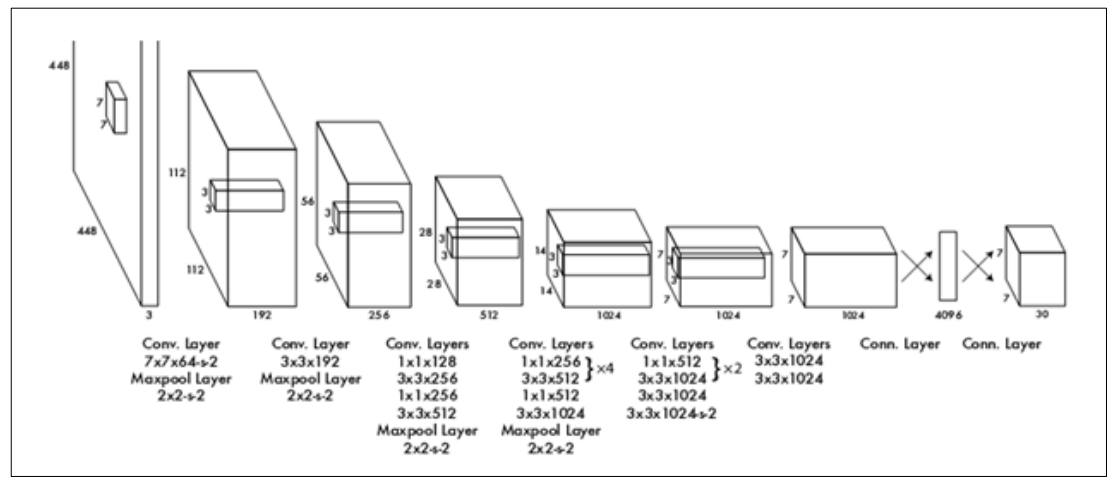

Fig. 3. YOLO architecture ${ }^{7}$

Further, based on the ideas proposed in the YOLO, was developed SSD (Single Shot Multi Box Detector) ${ }^{8}$, RetinaNet ${ }^{9}$ and others.

In 2019, researchers proposed a new approach to object detection that was implemented in CenterNet algorithms ${ }^{10}$.

Under the concept of tracking detected objects, we will understand the process of localization of a moving object or several moving objects on a sequence of frames.

Tracking algorithms, in contrast to detection algorithms, are able to solve the problems of such adverse conditions as occlusion (the object is partially or completely blocked), motion blur, complex background, lighting changes.

Maintenance algorithms can be classified according to the following criteria:

1. By the number of objects accompanied by:

- for single object tracking-SOT (single object tracker);

- for tracking multiple objects-MOT (multiple object tracker)

2. According to the method of support:

- tracking on the basis of detection (frames with previously identified object, are consistently processed by the tracker, which foresees the location of the object on the next frame and forms a trajectory);

${ }^{8}$ Liu W., Anguelov D., Erhan D., Szegedy C., Reed S.E., Fu C., Berg A.C. (2016) SSD: Single Shot MultiBox Detector. ECCV. DOI: 10.1007/978-3-319-46448-0_2. (in English)

${ }_{9}^{9}$ Lin T., Goyal P., Girshick R.B., He K., Dollár P. (2017) Focal Loss for Dense Object Detection. 2017 IEEE International Conference on Computer Vision (ICCV), pp. 2999-3007. DOI: 10.1109/ICCV.2017.324. (in English)

${ }^{10}$ Zhou X., Wang D., Krähenbühl P. (2019) Objects as Points. ArXiv, abs/1904.07850. (in English) 
- maintenance without detection (manual initialization of the «object of interest» on the first frame is required).

3. The method of obtaining frames:

- support from the video stream recorded on the information screen (the algorithm for analysis can use not only the previous frames, but also the next ones);

- video stream tracking in real-time mode (the algorithm can use only previous frames for analysis).

4. According to the method of organization of training strategy:

- real-time learning (algorithm analyzes pre-initialized frame and multiple previous frames)

- training on the basis of previously received information about the «object of interest».

One group of scientists divides the existing methods of tracking identified objects into the following categories: methods are based on tracking by «control» points, methods are based on the centers of mass of objects (core), methods are based on tracking along the contours of objects $^{11,12,13}$.

Another group of scientists divides the methods of maintenance into categories:

- tracking by the sites of objects;

- tracking by the contours;

- tracking by the boundaries ${ }^{14,15,16}$

In our research, we tend to the opinion of the first group of scientists on the classification of tracking methods into such groups as the methods are based on tracking by «control» points, the goals are based on tracking by the

${ }^{11}$ Patil H., Bhagat K. (2015) Detection and tracking of moving object: A survey. Int. Journal of Engineering Research and Applications. vol.5 no. 11. pp.138-142. (in English)

${ }^{12}$ Grandham Sindhuja, Renuka Devi. (2015) A survey on detection and tracking of objects in video sequence. International Journal of Engineering Research and General Science. vol. 3 no. 2. (in English)

${ }^{13}$ Yilmaz A., Javed O. A., Shah M. (2006) Object tracking: A survey. ACM Comput. Surv., vol. 38, no. 13. (in English)

${ }^{14}$ Barga Deori and Dalton Meitei Thounaojam. (2014) A survey on moving object tracking in video. International Journal on Information Theory (IJIT). vol.3, no.3 pp. 31-46. DOI: 10.5121/ijit.2014.3304. (in English)

${ }^{15}$ Ann Maria Jacob and J Anitha (2012) Inspection of various object tracking techniques. International Journal of Engineering and Innovative Technology. vol. 2, no. 6, pp. 118-124. (in English)

${ }^{16}$ Ojha S., Sakhare S. (2015) Image processing techniques for object tracking in video surveillance - A survey. 2015 International Conference on Pervasive Computing (ICPC), pp. 1-6. DOI: 10.1109/PERVASIVE.2015.7087180. (in English) 
centers of mass of objects (core), the methods are based on tracking by the contours of objects.

\section{Analysis of modern tracking algorithms}

We chose Python 3.6 and OpenCV as our development environment. The OpenCV library since version 3.4 contains such algorithms of maintenance of objects as: Boosting, MIL, KCF, TLD, MedianFlow, GoTurn, MOSSE, CSRT.

For experimental research, most often used sets such as Object Tracking Benchmark, Visual Object Tracking, etc. For example, to assess the results of these algorithms was taken video consequence from video surveillance cameras that operate in conditions close to the conditions of the real application of video surveillance systems of the State guard border service of Ukraine. For the research we chose the following algorithms:

The Boosting method is based on real-time object tracking and is based on the AdaBoost algorithm. This method was proposed in article ${ }^{17}$.

The CSRT method is described in article ${ }^{18}$, and is based on the concept of discriminatory correlation filters (DCF). Despite the use of simple functions such as HoG and Colornames, this method works on a par with trackers, which are built on more computationally complex neural network methods and provides information processing in real time.

TLD was presented in article ${ }^{19}$ is based on the concept of splitting the long-term maintenance task into short-term maintenance, training and identification. The tracker tracks the object from frame to frame, the detector localizes all previously detected objects and corrects the tracker as needed. The learning process evaluates the detector errors and updates it to avoid these errors in the future. It is based on the MedianFlow median flow tracking algorithm. It is characterized by being able to handle rapid movements, partial occlusions, the absence of objects and the like.

MedianFlow is a method described in article ${ }^{20}$. In this paper proposed a measure, Forward-Backward error, that estimates reliability of a trajectory.

17 Grabner H., Grabner M., Bischof H. (2006) Real-Time Tracking via On-line Boosting. BMVC. (in English)

${ }^{18}$ Lukezic A., Vojír T., Zajc L.C., Matas J.E., Kristan M. (2017) Discriminative Correlation Filter Tracker with Channel and Spatial Reliability. International Journal of Computer Vision, vol. 126, pp. 671-688. DOI: 10.1109/CVPR.2017.515. (in English)

${ }^{19}$ Kalaz Z. (2011) Tracking-Learning-Detection. IEEE Transactions on Pattern Analysis and Machine Intelligence, vol. 34, pp. 1409-1422. DOI: 10.1109/TPAMI.2011.239. (in English)

${ }^{20}$ Kalal Z., Mikolajczyk K., Matas J.E. (2010) Forward-Backward Error: Automatic Detection of Tracking Failures. 2010 20th International Conference on Pattern Recognition, pp. 2756-2759. (in English) 
A validation trajectory is constructed by backward tracking and compared to the trajectory in question. The implementation only involves applying the same tracking algorithm on a reversed sequence of images. Suitable for smooth and predictable movements of objects that fit completely into the frame image $e^{20}$.

The algorithm KCF (Kernelized Correlation Filter) was presented in $\operatorname{articles}^{21,22}$ uses the properties of the circulant matrix to increase the speed of information processing. The methods of circulants and regularization by Tikhonov are used for calculations in the cortical filter. The algorithm is based on the use of the directed gradient histogram (HOG) method.

The MOSSE (Minimum Output Sum of Squared Error) algorithm was presented in article ${ }^{23}$. Works with grayscale images and is based on the use of adaptive correlation filters to accompany visual objects.

The MIL was presented in article ${ }^{24}$. This paper presents a new type of correlation filter, a Minimum Output Sum of Squared Error (MOSSE) filter, which produces stable correlation filters when initialized using a single frame. A tracker based upon MOSSE filters is robust to variations in lighting, scale, pose, and non-rigid deformations while operating at 669 frames per second. Occlusion is detected based upon the peak ratio, which enables the tracker to pause and resume where it left off when the object reappears The method trains the classifier in real-time separation of the object from the background.

MeanShift is the method proposed in article ${ }^{25}$. It is based on the technique of analyzing the feature space for the order of the maximum probability density. The MeanShift algorithm tries to find the area of the video frame that is locally most similar to the previously initialized area.

\footnotetext{
${ }^{21}$ Henriques J., Caseiro R., Martins P., Batista J. (2012) Exploiting the Circulant Structure of Tracking-by-Detection with Kernels. ECCV. DOI: 10.1007/978-3-642-33765-9_50. (in English)

${ }^{22}$ Henriques J.F., Caseiro R., Martins P., Batista J. (2015) High-Speed Tracking with Kernelized Correlation Filters. IEEE Transactions on Pattern Analysis and Machine Intelligence, vol.37, pp. 583-596. DOI: 10.1109/TPAMI.2014.2345390. (in English)

${ }^{23}$ Bolme D. S., Beveridge J. R., Draper B. A., Lui Y. M. (2010) Visual object tracking using adaptive correlation filters. 2010 IEEE Computer Society Conference on Computer Vision and Pattern Recognition, pp. 2544-2550. DOI: 10.1109/CVPR.2010.5539960. (in English)

${ }^{24}$ Babenko B., Yang M., Belongie S. (2009) Visual tracking with online Multiple Instance Learning. 2009 IEEE Conference on Computer Vision and Pattern Recognition, pp. 983-990. DOI: 10.1109/CVPR.2009.5206737. (in English)

${ }^{25}$ Comaniciu D., Meer P. (2002) Mean Shift: A Robust Approach Toward Feature Space Analysis. IEEE Trans. Pattern Anal. Mach. Intell., vol. 24, pp. 603-619. DOI: 10.1109/34.1000236. (in English)
} 
CamShift is a method proposed $\mathrm{in}^{26}$ based on the segmentation algorithm proposed by Gary Bradsky in 1998.

GOTURN is a method proposed in article $^{27}$ based on the use of convolutional neural map. Due to this, the method without any additional settings in real time solves the problem of object maintenance. The specified method on a way of the organization of strategy of training belongs to algorithms working on the basis of previously received information on object of interest, that is in the course of work you do not study, and uses already ready data models. The disadvantage of this method is that it does not handle occlusions, but at the same time it is reliable enough to accompany the object in complex conditions such as changes in lighting and deformation.

\section{Eperimental results and considering the analysis of the results of VOT}

On the basis of the experiment, taking into account the pre-defined tasks that should implement intelligent video surveillance systems of the State border guard service, we have reached the following conclusions:

1. To implement the function of detecting the intersection of objects crossing the conditional line (detection of objects approaching or crossing the fence), it is more expedient to use algorithms based on neural network methods, since a person who approaches the fence during his movement can crouch, lie down, bend and group while changing the shape of his visual display. During the experiment, the algorithms are based on the use of Haar cascades and histograms of directional gradients (HOG) when changing the geometric shape of the detected moving object, there is no intersection of the conditional line, while reducing the threshold value of the area of the detected moving object leads to erroneous results of the algorithm due to external factors (movement of tree crowns, wind gusts, changes in lighting, etc.).

2. To implement the function of counting the number of persons and/or vehicles that cross a conditional line defined by the operator and do not significantly change their geometric proportions during movement, acceptable results of the work were shown by the algorithms KCF, MIL, MOSSE, GoTurn (neural networks algorhythm). Unsatisfactory results were shown by the algorithms CSRT, TLD, Boosting, MedianFlow, MeanShift, Cam-Shift (delays in processing video frames, detection of moving objects).

\footnotetext{
${ }^{26}$ Bradski G. R. (1998) Real time face and object tracking as a component of a perceptual user interface. Proceedings Fourth IEEE Workshop on Applications of Computer Vision. WACV'98 (Cat. No.98EX201), pp. 214-219. DOI: 10.1109/ACV.1998.732882. (in English)

${ }^{27}$ Held D., Thrun S., Savarese S. (2016) Learning to Track at 100 FPS with Deep Regression Networks. ECCV. DOI: 10.1007/978-3-319-46448-0_45. (in English)
} 
Also, on the basis of the analysis of the results of VOT- $2018^{28}$ (table 1), it was determined that currently the dominant methods in solving the problem of object maintenance in the video sequences are neural network approaches and discriminative correlation filters.

A characteristic feature of VOT-2018, unlike the previous ones, is that the best results in the categories (short-term, long-term, real-time, with short-term disappearances of objects) are shown by the algorithms built on the architectures of Siamese neural networks. The best compromise between reliability and processing speed can be achieved through the use of GPU.

Scientists use certain metrics to evaluate the performance of algorithms. In the simplest case, such a metric could be the proportion of samples by which the classifier made the right decision.

$$
\text { Accuracy }=\frac{P}{N}
$$

Where $P$ is the number of correctly classified objects and $N$ is the total number of objects.

In Table 1:

A - accuracy, reflects how accurately the algorithm determines the position of the object;

$$
\varphi_{t}=\frac{A_{t}^{G} \cap A_{t}^{T}}{A_{t}^{G} \cup A_{t}^{T}}
$$

where: $A_{t}^{T}$ - define tracker predicted bounding box and $A_{t}^{G}-$ define ground truth bounding box.

$\mathrm{R}$ - robustness, defines the amount of time when algorithm «loses» the object of interest;

EAO - expected average overlap, calculated as the average of the expected average overlap curve values over an interval of typical short-term sequence lengths.

28 Kristan Matej (2018) The Sixth Visual Object Tracking VOT2018 Challenge Results." ECCV Workshops (2018). The Sixth Visual Object Tracking VOT2018 Challenge Results. ECCV Workshops. URL : http://votchallenge.net/publications.html. DOI: 10.1007/9783-030-11009-3_1. (in English) 
Expected average overlap measure, computed as the average of the expected average overlap curve values over an interval $N_{l o}: N_{h i}$ of typical sequence lengths ${ }^{29}$.

$$
\begin{gathered}
\stackrel{€}{\Phi}=\frac{1}{N_{h i}-N_{l o}} \sum_{N_{S}=N_{l o}: N_{h i}} \stackrel{€}{\Phi^{\prime}} N_{S} \\
\Phi_{N_{S}}=\frac{1}{N_{S}} \sum_{i=1: N_{S}} \Phi_{i} \\
{\stackrel{Ð}{\Phi} N_{S}=\left\langle\Phi_{N_{S}}\right\rangle}^{€}
\end{gathered}
$$

CPU is a central processing unit; GPU is a graphics processing unit;

Table 1

\section{Experimental results of the work} of the tracking algorithms on VOT-2018

\begin{tabular}{|c|c|c|c|c|}
\hline Algorythm & EAO & A & R & Controlled by CPU or GPU \\
\hline LADCF & 0.066 & 0.314 & 1.358 & CPU \\
\hline MFT & 0.060 & 0.337 & 1.592 & GPU \\
\hline SiamRPN & 0.3831 & 0.5861 & 0.276 & GPU \\
\hline UPDT & 0.068 & 0.334 & 1.363 & CPU \\
\hline RCO & 0.066 & 0.400 & 1.704 & GPU \\
\hline DRT & 0.062 & 0.321 & 1.503 & GPU \\
\hline DeepSTRCF & 0.063 & 0.418 & 1.817 & GPU \\
\hline CPT & 0.081 & 0.479 & 1.358 & GPU \\
\hline SA Siam R & 0.3372 & 0.5662 & 0.258 & GPU \\
\hline DLSTpp & 0.125 & 0.514 & 0.824 & GPU \\
\hline LSART & 0.055 & 0.386 & 1.971 & GPU \\
\hline SRCT & 0.059 & 0.331 & 1.765 & CPU \\
\hline CFTR & 0.062 & 0.319 & 1.601 & GPU \\
\hline CPT fast & 0.152 & 0.515 & 0.726 & GPU \\
\hline DeepCSRDCF & 0.062 & 0.399 & 1.644 & GPU \\
\hline SiamVGG & 0.275 & 0.531 & 0.337 & GPU \\
\hline SA Siam P & 0.2863 & 0.5333 & 0.342 & GPU \\
\hline CFCF & 0.059 & 0.326 & 1.648 & GPU \\
\hline ECO & 0.078 & 0.449 & 1.466 & GPU \\
\hline MCCT & 0.061 & 0.359 & 1.742 & CPU \\
\hline CCOT & 0.058 & 0.326 & 1.461 & GPU \\
\hline
\end{tabular}

${ }^{29}$ Kristan M., Matas J., Leonardis A., Felsberg M., Cehovin L., Fernández G., Vojír T., Häger G., Nebehay G., Pflugfelder R.P. (2015) The Visual Object Tracking VOT2015 Challenge Results. 2015 IEEE International Conference on Computer Vision Workshop (ICCVW), pp. 564-586. DOI: 10.1109/ICCVW.2015.79. (in English) 


\begin{tabular}{|c|c|c|c|c|}
\hline Algorythm & EAO & $\mathbf{A}$ & $\mathbf{R}$ & Controlled by CPU or GPU \\
\hline csrtpp & 0.263 & 0.466 & 0.318 & GPU \\
\hline LWDNTthi & 0.262 & 0.463 & 0.342 & GPU \\
\hline LWDNTm & 0.261 & 0.455 & 0.323 & S P G \\
\hline R MCPF & 0.064 & 0.329 & 1.391 & GPU \\
\hline FSAN & 0.065 & 0.312 & 1.377 & GPU \\
\hline CSRDCF & 0.099 & 0.477 & 1.054 & $\mathrm{CPU}$ \\
\hline DCFCF & 0.080 & 0.321 & 0.665 & $\mathrm{CPU}$ \\
\hline UpdateNet & 0.209 & 0.517 & 0.534 & GPU \\
\hline MBSiam & 0.238 & 0.529 & 0.440 & GPU \\
\hline ALAL & 0.067 & 0.404 & 1.667 & GPU \\
\hline CSTEM & 0.239 & 0.472 & 0.379 & $\mathrm{CPU}$ \\
\hline BoVW CFT & 0.063 & 0.331 & 1.615 & $\mathrm{CPU}$ \\
\hline C3DT & 0.067 & 0.322 & 1.330 & GPU \\
\hline RSECF & 0.074 & 0.414 & 1.569 & GPU \\
\hline DSiam & 0.129 & 0.503 & 0.979 & GPU \\
\hline KFebT & 0.195 & 0.475 & 0.670 & $\mathrm{CPU}$ \\
\hline MEEM & 0.072 & 0.407 & 1.592 & $\mathrm{CPU}$ \\
\hline SiamFC & 0.182 & 0.502 & 0.604 & GPU \\
\hline STST & 0.156 & 0.466 & 0.763 & GPU \\
\hline DCFNet & 0.180 & 0.471 & 0.548 & GPU \\
\hline DensSiam & 0.174 & 0.462 & 0.688 & GPU \\
\hline SAPKLTF & 0.117 & 0.481 & 0.946 & $\mathrm{CPU}$ \\
\hline Staple & 0.170 & 0.530 & 0.688 & $\mathrm{CPU}$ \\
\hline ASMS & 0.167 & 0.492 & 0.632 & $\mathrm{CPU}$ \\
\hline ANT & 0.059 & 0.403 & 1.737 & $\mathrm{CPU}$ \\
\hline HMMTxD & 0.073 & 0.416 & 1.564 & $\mathrm{CPU}$ \\
\hline DPT & 0.126 & 0.483 & 0.899 & $\mathrm{CPU}$ \\
\hline STBACF & 0.062 & 0.320 & 0.2813 & $\mathrm{CPU}$ \\
\hline srdcf deep & 0.057 & 0.326 & 1.756 & GPU \\
\hline PBTS & 0.102 & 0.411 & 1.100 & $\mathrm{CPU}$ \\
\hline DAT & 0.139 & 0.436 & 0.749 & $\mathrm{CPU}$ \\
\hline LGT & 0.059 & 0.349 & 1.714 & $\mathrm{CPU}$ \\
\hline RAnet & 0.133 & 0.477 & 0.805 & GPU \\
\hline DFPReco & 0.049 & 0.312 & 0.286 & $\mathrm{CPU}$ \\
\hline TRACA & 0.136 & 0.424 & 0.857 & GPU \\
\hline KCF & 0.134 & 0.445 & 0.782 & $\mathrm{CPU}$ \\
\hline FoT & 0.130 & 0.393 & 1.030 & $\mathrm{CPU}$ \\
\hline srdcf dif & 0.061 & 0.398 & 1.925 & GPU \\
\hline SRDCF & 0.058 & 0.377 & 1.999 & $\mathrm{CPU}$ \\
\hline MIL & 0.069 & 0.376 & 1.775 & $\mathrm{CPU}$ \\
\hline BST & 0.053 & 0.271 & 1.620 & $\mathrm{CPU}$ \\
\hline struck2011 & 0.093 & 0.419 & 1.367 & $\mathrm{CPU}$ \\
\hline BDF & 0.093 & 0.367 & 1.180 & $\mathrm{CPU}$ \\
\hline Matflow & 0.090 & 0.401 & 1.297 & $\mathrm{CPU}$ \\
\hline MRSNCC & 0.060 & 0.328 & 2.088 & $\mathrm{CPU}$ \\
\hline DSST & 0.077 & 0.396 & 1.480 & $\mathrm{CPU}$ \\
\hline IVT & 0.065 & 0.386 & 1.854 & $\mathrm{CPU}$ \\
\hline CPOINT & 0.057 & 0.290 & 1.901 & $\mathrm{CPU}$ \\
\hline
\end{tabular}




\begin{tabular}{|c|c|c|c|c|}
\hline Algorythm & EAO & A & R & Controlled by CPU or GPU \\
\hline L1APG & 0.062 & 0.351 & 1.831 & CPU \\
\hline FragTrack & 0.068 & 0.316 & 1.480 & CPU \\
\hline Matrioska & 0.000 & 0.000 & 16.740 & CPU \\
\hline
\end{tabular}

\section{CONCLUSIONS}

Given the above experimental results and considering the analysis of the results of VOT-2018, we came to conclusion that in the intellectual surveillance of the State border guard service of Ukraine to implement the predefined tasks, it is advisable to apply integrated approaches to the construction of algorithms of detection and tracking of objects in video sequences. Such complex approaches should make it possible to apply to the choice of the user the system algorithms built on neural network approaches or on the so-called traditional approaches (HOG, HAAR, Colornames, etc.).

Taking into account that tracking algorithms solve two problems: detection and tracking, and accordingly each of the stages must be studied and evaluated by different indicators, we consider it necessary to continue research in the following areas: analysis of algorithms for object detection and analysis of algorithms for tracking detected objects.

\section{SUMMARY}

One of the functions of intelligent video surveillance systems is the detection of objects crossing a conditional line on video sequences. Based on the analysis of research results of world leading scientists it was established that in order to for implement the above function it is necessary to solve the following problems: identifying objects, their localization, tracking from frame to frame and fixing the moment of crossing the group of pixels belonging to the «object of interest» with the pixels that belong to the «imaginary line».

The purpose of the article is to study the algorithms of object tracking in video sequences for further practical implementation in the processes of automatic processing of video information obtained from video surveillance cameras.

A review analysis of algorithms for object detection and tracking was performed, in the result of which the way to classify the algorithms of objects tracking was represented. Also, an experimental study of a number of tracking algorithms was conducted, as a result of which the recommendations were formed regarding the conditions of application of these algorithms for the purpose of their quantitative comparative evaluation and decomposition of detection and tracking problems. 
As a result of the study, a classification of algorithms for object tracking was proposed. Recommendations on the conditions of application of these algorithms in real conditions were elaborated.

The analysis confirmed the importance of research algorithms for processing video information from video surveillance cameras and made it possible to identify the main directions of further research: analysis of algorithms for object detection and analysis of algorithms for tracking detected objects.

\section{REFERENCES}

1. Katerynchuk I., Babaryka A. (2018) Doslidzhennya algoritmiv viyavlennya ta suprovodzhennya ruhomih ob'yektiv u videoposlidovnostyah $\mathrm{z}$ kamer videosposterezhennya. [Analysis of the Technologies of the Functioning Specific Video Surveillance Systems and the Definition of their Directions of Improvement]. Collection of scientific works of the National Academy of the State Border Guard Service of Ukraine. Series: Military and Technical Science. no. 3(77). pp. 246-259 (in Ukrainian).

2. Zou Z., Shi Z., Guo Y., \& Ye J. (2019) Object Detection in 20 Years: A Survey. ArXiv, abs/1905.05055. (in English)

3. Viola P. A., \& Jones M. J. (2001) Rapid object detection using a boosted cascade of simple features. Proceedings of the 2001 IEEE Computer Society Conference on Computer Vision and Pattern Recognition. CVPR 2001, 1, I-I. DOI: 10.1109/CVPR.2001.990517. (in English)

4. Viola P. A., Jones M. J. (2001) Robust real-time face detection. Proceedings Eighth IEEE International Conference on Computer Vision. ICCV 2001, no. 2, pp. 747-747. DOI: 10.1023/B:VISI.0000013087.49260.fb. (in English)

5. Dalal N., Triggs B. (2005) Histograms of oriented gradients for human detection. 2005 IEEE Computer Society Conference on Computer Vision and Pattern Recognition (CVPR'05), 1, 886-893 vol. 1. (in English)

6. Felzenszwalb P. F., McAllester D. A., Ramanan D. (2008) A discriminatively trained, multiscale, deformable part model. 2008 IEEE Conference on Computer Vision and Pattern Recognition, pp. 1-8. DOI: 10.1109/CVPR.2008.4587597. (in English)

7. Redmon J., Divvala S.K., Girshick R.B., Farhadi A. (2015) You Only Look Once: Unified, Real-Time Object Detection. 2016 IEEE Conference on Computer Vision and Pattern Recognition (CVPR), pp. 779-788. DOI: 10.1109/CVPR.2016.91. (in English)

8. Liu W., Anguelov D., Erhan D., Szegedy C., Reed S.E., Fu C., Berg A.C. (2016) SSD: Single Shot MultiBox Detector. ECCV. DOI: 10.1007/978-3-319-46448-0_2. (in English) 
9. Lin T., Goyal P., Girshick R.B., He K., Dollár P. (2017) Focal Loss for Dense Object Detection. 2017 IEEE International Conference on Computer Vision (ICCV), pp. 2999-3007. DOI: 10.1109/ICCV.2017.324. (in English)

10. Zhou X., Wang D., Krähenbühl P. (2019) Objects as Points. ArXiv, abs/1904.07850. (in English)

11. Patil H., Bhagat K. (2015) Detection and tracking of moving object: A survey. Int. Journal of Engineering Research and Applications. vol.5 no. 11. pp.138-142. (in English)

12. Grandham Sindhuja, Renuka Devi. (2015) A survey on detection and tracking of objects in video sequence. International Journal of Engineering Research and General Science. vol. 3 no. 2. (in English)

13. Y1lmaz A., Javed O. A., Shah M. (2006) Object tracking: A survey. ACM Comput. Surv., vol. 38, no. 13. (in English)

14. Barga Deori and Dalton Meitei Thounaojam. (2014) A survey on moving object tracking in video. International Journal on Information Theory (IJIT). vol. 3, no. 3 pp. 31-46. DOI: 10.5121/ijit.2014.3304. (in English)

15. Ann Maria Jacob and J Anitha (2012) Inspection of various object tracking techniques. International Journal of Engineering and Innovative Technology. vol. 2, no. 6, pp. 118-124. (in English)

16. Ojha S., Sakhare S. (2015) Image processing techniques for object tracking in video surveillance - A survey. 2015 International Conference on Pervasive Computing (ICPC), pp. 1-6. DOI: 10.1109/ PERVASIVE.2015.7087180. (in English)

17. Grabner H., Grabner M., Bischof H. (2006) Real-Time Tracking via On-line Boosting. BMVC. (in English)

18. Lukezic A., Vojír T., Zajc L.C., Matas J.E., Kristan M. (2017) Discriminative Correlation Filter Tracker with Channel and Spatial Reliability. International Journal of Computer Vision, vol. 126, pp. 671688. DOI: 10.1109/CVPR.2017.515. (in English)

19. Kalaz Z. (2011) Tracking-Learning-Detection. IEEE Transactions on Pattern Analysis and Machine Intelligence, vol. 34, pp. 1409-1422. DOI: 10.1109/TPAMI.2011.239. (in English)

20. Kalal Z., Mikolajczyk K., Matas J.E. (2010) Forward-Backward Error: Automatic Detection of Tracking Failures. 2010 20th International Conference on Pattern Recognition, pp. 2756-2759. (in English)

21. Henriques J., Caseiro R., Martins P., Batista J. (2012) Exploiting the Circulant Structure of Tracking-by-Detection with Kernels. ECCV. DOI: 10.1007/978-3-642-33765-9_50. (in English)

22. Henriques J.F., Caseiro R., Martins P., Batista J. (2015) High-Speed Tracking with Kernelized Correlation Filters. IEEE Transactions on Pattern 
Analysis and Machine Intelligence, vol.37, pp. 583-596. DOI: 10.1109/TPAMI.2014.2345390. (in English)

23. Bolme D. S., Beveridge J. R., Draper B. A., Lui Y. M. (2010) Visual object tracking using adaptive correlation filters. 2010 IEEE Computer Society Conference on Computer Vision and Pattern Recognition, pp. 2544-2550. DOI: 10.1109/CVPR.2010.5539960. (in English)

24. Babenko B., Yang M., Belongie S. (2009) Visual tracking with online Multiple Instance Learning. 2009 IEEE Conference on Computer Vision and Pattern Recognition, pp. 983-990. DOI: 10.1109/CVPR.2009.5206737. (in English)

25. Comaniciu D., Meer P. (2002) Mean Shift: A Robust Approach Toward Feature Space Analysis. IEEE Trans. Pattern Anal. Mach. Intell., vol. 24, pp. 603-619. DOI: 10.1109/34.1000236. (in English)

26. Bradski G. R. (1998) Real time face and object tracking as a component of a perceptual user interface. Proceedings Fourth IEEE Workshop on Applications of Computer Vision. WACV'98 (Cat. No.98EX201), pp. 214-219. DOI: 10.1109/ACV.1998.732882. (in English)

27. Held D., Thrun S., Savarese S. (2016) Learning to Track at 100 FPS with Deep Regression Networks. ECCV. DOI: 10.1007/978-3-319-464480_45. (in English)

28. Kristan Matej (2018) The Sixth Visual Object Tracking VOT2018 Challenge Results." ECCV Workshops (2018). The Sixth Visual Object Tracking VOT2018 Challenge Results. ECCV Workshops. URL : http://votchallenge.net/publications.html. DOI: 10.1007/978-3-030-110093_1. (in English)

29. Kristan M., Matas J., Leonardis A., Felsberg M., Cehovin L., Fernández G., Vojír T., Häger G., Nebehay G., Pflugfelder R.P. (2015) The Visual Object Tracking VOT2015 Challenge Results. 2015 IEEE International Conference on Computer Vision Workshop (ICCVW), pp. 564-586. DOI: 10.1109/ICCVW.2015.79. (in English)

\section{Information about the author:} Anatolii Babaryka,

Post-graduate student, The National Academy of the State Border Guard Service of Ukraine named after Bohdan Khmelnytskyi, Khmelnytskyi, Ukraine, 46 Shevchenka str., Khmelnytskyi, 29007, Ukraine ORCID ID: orcid.org/0000-0001-8534-7764 
NOTES 
NOTES 
Publishing house "Liha-Pres"

9 Kastelivka str., Lviv, 79012, Ukraine 44 Lubicka str., Toruń, 87-100, Poland

Printed by the publishing house "Liha-Pres"

Passed for printing: December 26, 2019

A run of 150 copies. 